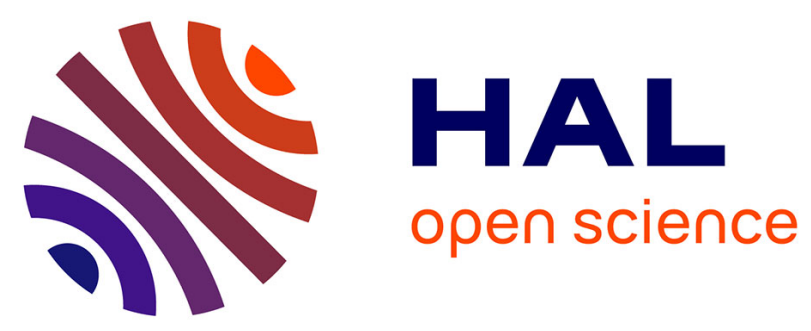

\title{
Thermo-responsive self-immolative nanoassemblies: Direct and indirect triggering
}

Bo Fan, John Frederick Trant, Gauvin C Hemery, Olivier Sandre, Elizabeth

R. Gillies

\section{- To cite this version:}

Bo Fan, John Frederick Trant, Gauvin C Hemery, Olivier Sandre, Elizabeth R. Gillies. Thermoresponsive self-immolative nanoassemblies: Direct and indirect triggering. Chemical Communications, 2017, 53 (89), pp.12068-12071. 10.1039/C7CC06410A . hal-01612697

\section{HAL Id: hal-01612697 \\ https://hal.science/hal-01612697}

Submitted on 5 Nov 2018

HAL is a multi-disciplinary open access archive for the deposit and dissemination of scientific research documents, whether they are published or not. The documents may come from teaching and research institutions in France or abroad, or from public or private research centers.
L'archive ouverte pluridisciplinaire HAL, est destinée au dépôt et à la diffusion de documents scientifiques de niveau recherche, publiés ou non, émanant des établissements d'enseignement et de recherche français ou étrangers, des laboratoires publics ou privés. 


\section{ChemComm}

\section{COMMUNICATION}

\section{Thermo-responsive self-immolative nanoassemblies: Direct and in- direct triggering}

Received 16th August 2017, Bo Fan, ${ }^{a}$ John F. Trant, ${ }^{b}$ Gauvin Hemery ${ }^{c}$, Olivier Sandre ${ }^{c}$ and Elizabeth R. Gillies*a,b

Accepted 5th October 2017

DOI: $10.1039 / c 7 c c 06410 a$

www.rsc.org/

\begin{abstract}
A thermo-responsive end-cap based on a retro-Diels-Alder and subsequent furan elimination reaction was developed. It was used to cap poly(ethyl glyoxylate), allowing end-to-end depolymerization upon thermal triggering. Using block copolymers, thermo-responsive micelles and vesicles were prepared and shown to disassemble upon heating. Thermal degradation could also be triggered indirectly by magnetic field hyperthermia after incorporation of iron oxide nanoparticles into the assemblies.
\end{abstract}

Nanoassemblies are of great interest due to their ability to mimic biological nanostructures and their capacity to perform diverse functions such as controlled release ${ }^{1}$, catalysis, ${ }^{2}$ and templating of inorganic structures. ${ }^{3}$ Stimuli-responsive macromolecular assemblies have attracted significant attention, ${ }^{4}$ due to their ability to undergo morphological or functional changes in response to stimuli. Assemblies responsive to stimuli such as light, ${ }^{5}$ heat, ${ }^{6}$ and $\mathrm{pH}^{7}$ have been reported. Heat is particularly attractive as it can be easily applied either directly with good spatiotemporal control, or indirectly through photothermal ${ }^{8}$ or magnetothermal effects ${ }^{9}$. Many examples of thermo-responsive polymer assemblies employing polymers such as poly $(N$ isopropylacrylamide) that undergo solubility changes in response to temperature have been reported. ${ }^{10}$ There are very few examples involving thermally-initiated bond cleavage. ${ }^{11}$

Over the last decade, a new class of stimuli-responsive polymers, often termed self-immolative polymers (SIPs), has been developed. These polymers can be triggered to degrade from end-to-end upon the cleavage of a stimulus-responsive end-cap from the terminus. ${ }^{12}$ The propagating depolymerization mechanism amplifies the stimulus-mediated event. Various backbones including polycarbamates, ${ }^{13}$ poly(benzyl ether)s, ${ }^{14}$ and

\footnotetext{
a. Department of Chemical and Biochemical Engineering, The University of Western Ontario, 1151 Richmond St., London, Canada N6A 5B9

b. Department of Chemistry, The University of Western Ontario, 1151 Richmond St., London, Canada N6A 5B9. E-mail: egillie@uwo.ca.

c. Laboratoire de Chimie des Polymères Organiques (LCPO), Université de Bordeaux, Bordeaux INP, ENSCBP, 16 avenue Pey Berland, Pessac, Cedex, France, 33607 Electronic Supplementary Information (ESI) available: experimental procedures, NMR, SEC, and DLS data, neutron scattering. See DOI: 10.1039/x0xx00000x
}

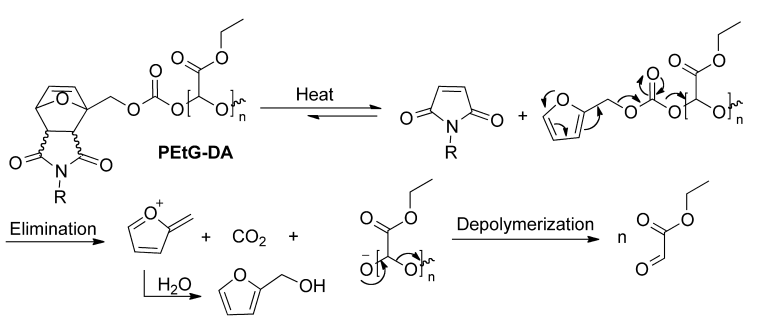

Scheme 1. Proposed end-cap cleavage and depolymerization mechanism of PEtG endcapped with a DA adduct (PEtG-DA).

polyaldehydes ${ }^{15-17}$ have been reported. A single SIP backbone can respond to different signals by simply changing the endcap. ${ }^{18}$ SIPs responsive to stimuli including light, ${ }^{19}$ oxidizing or reducing agents, ${ }^{20}$ and enzymes ${ }^{13}$ have been reported. Assemblies such as vesicles ${ }^{19}$ and micelles ${ }^{21}$ have been prepared from SIPs and shown to undergo disintegration and payload release in response to stimuli.

Thus far, one thermo-responsive SIP end-cap was reported. ${ }^{22}$ This 1,2-oxazine end-cap underwent cycloreversion to an unstable carbamoylnitroso intermediate that hydrolyzed and decarboxylated to initiate depolymerization. However, the endcapping was challenging, as it required generation of the unstable nitroso species to perform the cycloaddition. Furthermore, the end-cap cleavage and depolymerization were very slow, occurring over tens of days. Here we report that simple Diels-Alder (DA) adducts of furan and maleimides can serve as thermo-responsive end-caps. Upon heating, a retro-Diels Alder reaction occurs, revealing a furan. ${ }^{23}$ Based on the known instability of similarly substituted furan derivatives, ${ }^{24}$ it is proposed that the released furfuryl carbonate undergoes an elimination reaction to release an uncapped poly(ethyl glyoxylate) (PEtG) SIP for depolymerization (Scheme 1). Exploiting the easy synthetic modification of this end-cap, amphiphilic block copolymers can be prepared, and self-assembled into thermo-responsive vesicles and micelles. Furthermore, indirect triggering of SIP nanoas- 


\section{ChemComm}

semblies is demonstrated for the first time using the magnetothermal effect with iron oxide nanoparticles (IONPs) under an alternating magnetic field.

To test the proposed concept, we capped PEtG with the DA adduct and evaluated its thermo-responsiveness. First, $\mathrm{N}$-benzylmaleimide (1a) was reacted with furfuryl alcohol (2) in a DA reaction to obtain 3a as a 70:30 mixture of endo:exo diastereomers (Scheme 2). 3a was then activated as the chloroformate 4a. Polymerization of ethyl glyoxylate was conducted at $20{ }^{\circ} \mathrm{C}^{15}$ and the resulting PEtG was end-capped in situ by reaction with 4a to afford PEtG-DA-Bn (Scheme 3). The number average molecular weight $\left(M_{n}\right)$ was $33 \mathrm{~kg} / \mathrm{mol}$ and the dispersity $(\nexists)$ was 1.8 based on size exclusion chromatography (SEC). Successful end-capping was confirmed by thermogravimetric analysis as the capped polymer was stable to $>165^{\circ} \mathrm{C}$ in the solid state, whereas uncapped polymer degraded below $100{ }^{\circ} \mathrm{C}{ }^{15}$ (Fig. S28, Table S1).

To test the thermo-responsiveness of PEtG-DA-Bn, the polymer was dissolved in 9:1 $C D_{3} C N: D_{2} \mathrm{O}$ and incubated at different temperatures. A non-responsive PEtG end-capped by benzyl chloroformate (PEtG-control, Scheme S1) ${ }^{25}$ was also examined. The depolymerization was monitored by ${ }^{1} \mathrm{H}$ NMR spectroscopy. Initially, the spectrum of PEtG-DA-Bn consisted of broad peaks attributable to the polymer (Fig. 1). When the polymer was heated, a sharp peak at $5.1 \mathrm{ppm}$ corresponding to the depolymerization product ethyl glyoxylate hydrate (EtGH) emerged. The extent of depolymerization was quantified based on the integrations of polymer and EtGH peaks. Over $24 \mathrm{~h}, 85 \%$ depolymerization occurred at $75{ }^{\circ} \mathrm{C}, 53 \%$ at $60{ }^{\circ} \mathrm{C}$, and $8 \%$ at $40{ }^{\circ} \mathrm{C}$ (Figs. 2a, S22). In contrast, PEtG-DA-Bn at $22{ }^{\circ} \mathrm{C}$ and PEtG-control at $75{ }^{\circ} \mathrm{C}$ underwent less than $10 \%$ depolymerization even after 4 days (Figs. 2a, S21, S23). Overall, the rate of end-cap cleavage and depolymerization was much faster for PEtG-DABn than that of the previously reported oxazine system, ${ }^{22}$ which required several days, resulting in substantial background degradation of the controls. Thus, DA adducts can provide rapid and selective thermo-responsive degradation.

To prepare thermally-responsive assemblies from amphiphilic block copolymers, end-cap $4 \mathbf{b}$ with a propargyl group was synthesized (Scheme 2). $\mathbf{4 b}$ was installed on PEtG to afford PEtG-DA-alkyne with an $M_{n}$ of $63 \mathrm{~kg} / \mathrm{mol}$ and a $\oplus$ of 2.0 (Scheme $3)$. This polymer underwent depolymerization at rates very similar to those of PEtG-DA-Bn (Figs. 2a, S24-25). It was then coupled with two different lengths of azide-functionalized poly(ethylene glycol) (PEG-N $\mathrm{N}_{3} ; 750$ and $5000 \mathrm{~g} / \mathrm{mol}$ ) to give copolymers PEtG-DA-PEG750 and PEtG-DA-PEG5000. The success of the couplings was confirmed by SEC (Figs. S30-31) and ${ }^{1} \mathrm{H}$ NMR and ${ }^{13}$ C NMR spectroscopy (Figs. S15-18).

Assemblies were prepared by nanoprecipitation involving the addition of $\mathrm{H}_{2} \mathrm{O}$ into THF for PEtG-DA-PEG750 and DMSO into $\mathrm{H}_{2} \mathrm{O}$ for PEtG-DA-PEG5000. Based on dynamic light scattering (DLS), the Z-average diameters of the assemblies were 480 $\pm 80 \mathrm{~nm}$ for PEtG-DA-PEG750 and $87 \pm 3 \mathrm{~nm}$ for PEtG-DAPEG5000 (Figs. S33-34). Transmission electron microscopy (TEM) showed that PEtG-DA-PEG750 formed vesicles, while PEtG-DA-PEG5000 formed solid spherical nanoparticles (Fig. 3).

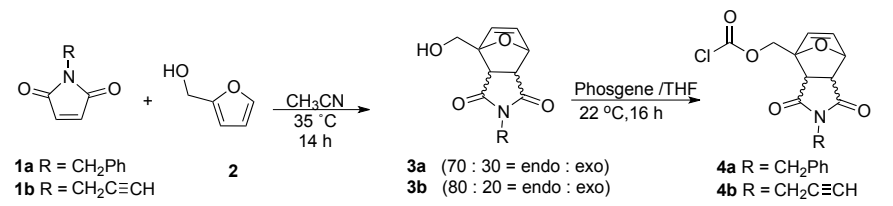

Scheme 2. Synthesis of end-caps $\mathbf{4 a}$ and $\mathbf{4 b}$.

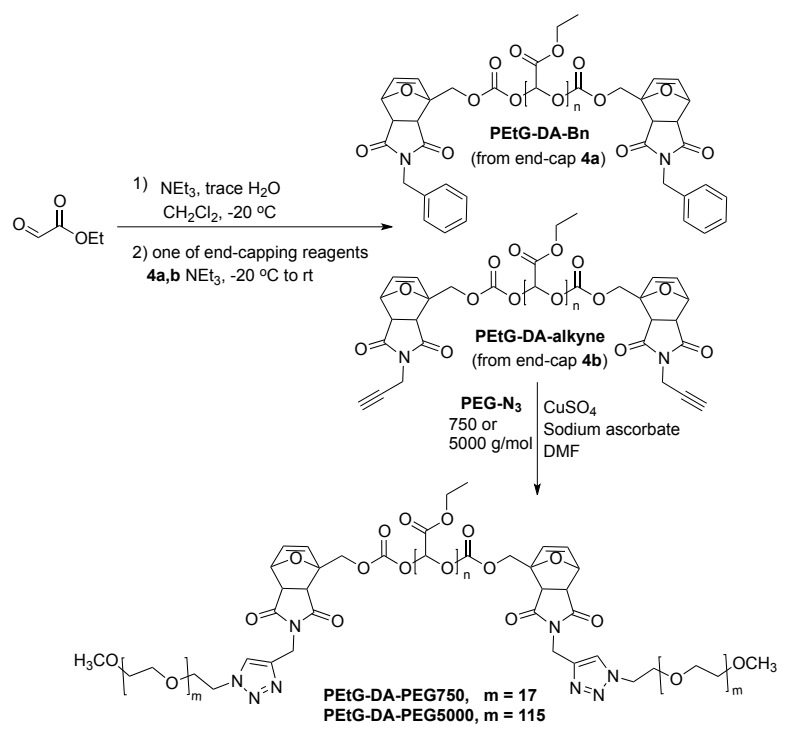

Scheme 3. Synthesis of end-capped PEtG and its block copolymers.

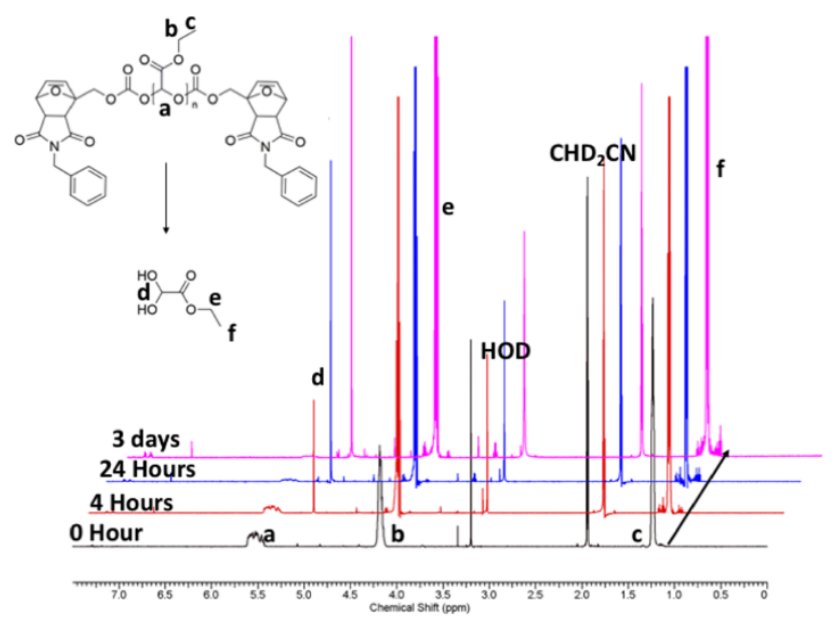

Fig. 1. ${ }^{1} \mathrm{H}$ NMR spectra of PEtG-DA-Bn incubated in 9:1 $\mathrm{CD}_{3} \mathrm{CN}: \mathrm{D}_{2} \mathrm{O}$ at $75^{\circ} \mathrm{C}$. Spectra are offset to allow the progression over time to be clearly observed.

After incubation of the assemblies at $75{ }^{\circ} \mathrm{C}$ for $16 \mathrm{~h}$, no remaining assemblies were detected by TEM (Fig. S37). This suggests that depolymerization of the PEtG resulted in disassembly. This disassembly was further probed using DLS by fixing the detector attenuation factor and recording the mean count rate (CR), which is proportional to the number and molar mass of the scattering species. Both the thermo-responsive vesicles and $\mathrm{mi}-$ celles prepared from PEtG-DA-PEG750 and PEtG-DA-PEG5000 showed an $80 \%$ decrease in CR when incubated at $75{ }^{\circ} \mathrm{C}$ for 10 h (Fig. 2b). In contrast, when these systems were incubated at $22{ }^{\circ} \mathrm{C}$ less than a $20 \%$ change in CR was observed. To ensure 


\section{ChemComm}
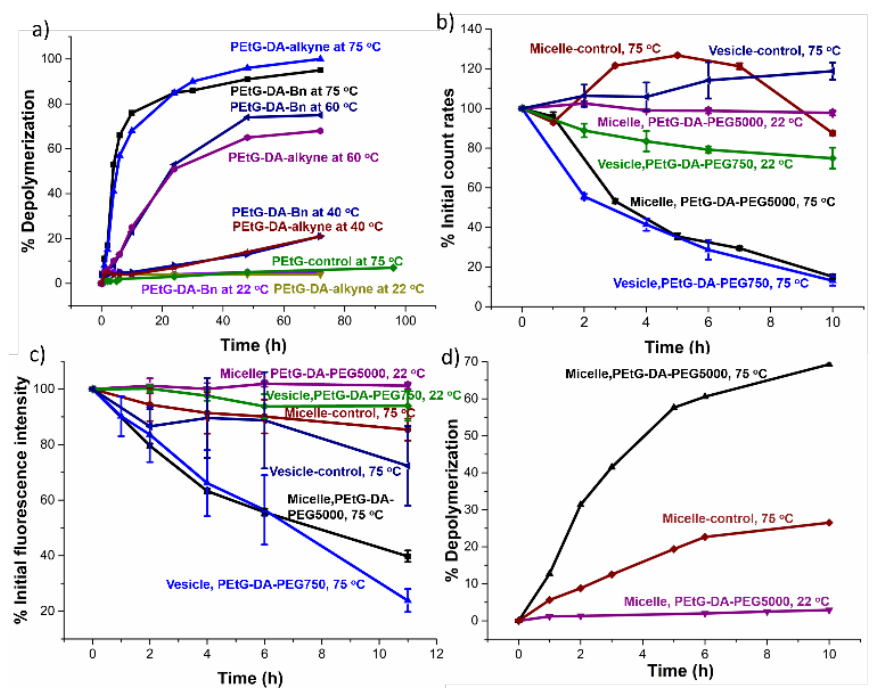

Fig. 2. a) Depolymerization of polymers in $9: 1 \mathrm{CD}_{3} \mathrm{CN}: \mathrm{D}_{2} \mathrm{O}$ monitored by NMR spectroscopy; Assembly degradation in $\mathrm{pH} 7.4$ phosphate buffer monitored by b) DLS count rate changes, c) Nile red fluorescence changes, and d) NMR spectroscopy.

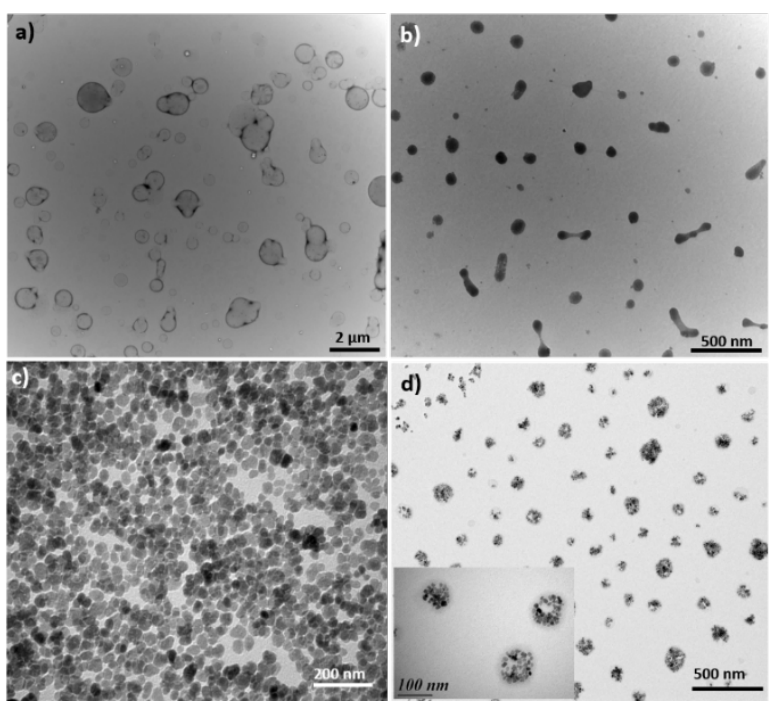

Fig. 3. TEM images of a) PEtG-DA-PEG750 vesicles, b) PEtG-DA-PEG5000 micelles, c) unloaded IONPs, d) IONP-loaded PEtG-DA-PEG5000 micelles.

that the degradation at $75{ }^{\circ} \mathrm{C}$ did not arise from non-specific thermal bond cleavage, we prepared additional vesicle and $\mathrm{mi}-$ celle controls (Vesicle-control and Micelle-control) from previously reported PEtG-PEG block copolymers containing a photocleavable nitrobenzyl end-cap/linker, that should not be thermo-responsive (Scheme S1). ${ }^{15}$ For both of these systems, the CR initially increased, which could be attributed to some aggregation, but it remained within $20 \%$ of its initial value.

The release of cargo from the vesicles and micelles was also explored. Nile red is a hydrophobic dye with strong fluorescence emission in a hydrophobic environment, but greatly reduced fluorescence due to quenching in hydrophilic environments such as water. Nile red was incorporated into the responsive vesicles and micelles as well as their corresponding controls. When the thermo-responsive assemblies were incubated at 75
${ }^{\circ} \mathrm{C}$, the fluorescence intensity of Nile red decreased by $60-70 \%$ over $11 \mathrm{~h}$ (Fig. 2c), consistent with its release into the aqueous environment. However, for either the same assemblies incubated at $22{ }^{\circ} \mathrm{C}$ or the non-thermo-responsive controls incubated at $75{ }^{\circ} \mathrm{C}$, only $\sim 10-20 \%$ intensity decrease was observed after $11 \mathrm{~h}$.

To confirm that breakdown of the assemblies was induced by the depolymerization of the PEtG blocks, the depolymerisation of PEtG-DA-PEG5000 micelles was studied by ${ }^{1} \mathrm{H}$ NMR spectroscopy. In this case, the assemblies were prepared by nanoprecipitation of the polymer in DMSO- $d_{6}$ into $\mathrm{pH} 7.4$ phosphate buffered $\mathrm{D}_{2} \mathrm{O}$ (DMSO- $d_{6}$ : $\mathrm{D}_{2} \mathrm{O}=1: 5$ ). Only the peak corresponding to the PEG block was observed initially, consistent with selfassembly of PEtG at the particle cores (Fig. S26). However, after $1 \mathrm{~h}$ at $75{ }^{\circ} \mathrm{C}$, peaks corresponding to $\mathrm{EtGH}$ appeared, confirming depolymerization. As shown in Fig. 2d, 65\% depolymerization had occurred over $10 \mathrm{~h}$ at $75{ }^{\circ} \mathrm{C}$, whereas less than $5 \%$ depolymerisation occurred at $22{ }^{\circ} \mathrm{C}$. For Micelle-control, at $75{ }^{\circ} \mathrm{C}$, there was only about $20 \%$ depolymerization, which could be induced by nonspecific hydrolysis of the carbonate group of the end-cap. Combined, these data support that the thermo-responsive assemblies can degrade in response to external heat, and that this is due to the thermally responsive end-cap.

For some applications, direct bulk heating to trigger depolymerisation can be a viable process. However, in other cases, it would be necessary to apply a more selective and localized heating. Therefore, we also explored the incorporation of IONPs into the micelle core and the use of magnetic field hyperthermia (MFH) to obtain localized heating around the IONPs. This magnetothermal effect has previously been shown to enable a similar cleavage of bonds at the IONP surface. ${ }^{26}$

Hydrophobic IONPs were synthesized via the "polyol" process (11.2 $\pm 1.9 \mathrm{~nm}$ diameter, Fig. 3c), ${ }^{8}$ and then coated with Beycostat NE surfactant to be incorporated into the micelle cores via nanoprecipitation of co-assembled IONPs and PEtGDA-PEG5000 from a THF solution into water. ${ }^{27}$ The pure micelle solution was transparent and colorless. When the IONPs were introduced, the colloidal suspension became brown and darkened as the concentration of iron increased (Fig. S39). However, even at 35 mass \% of IONP relative to polymer, the suspension was still transparent, confirming the IONPs were well dispersed and not precipitating. TEM showed that the IONPs were aggregated in spherical shapes with dimensions of $\sim 100 \mathrm{~nm}$ (Fig. 3d).

Samples with the highest IONP content of 35 mass\%, theoretically able to produce the largest increases of temperature, were studied. Micelle-control was also loaded with IONPs. The samples were first heated to $72{ }^{\circ} \mathrm{C}$ and equilibrated for $1 \mathrm{~h}$. The Z-average particle diameter and scattering $C R$ were measured using an in situ MFH-DLS setup as previously reported (Fig. S40). ${ }^{9}$ No changes in CR or diameter were observed during the initial $1 \mathrm{~h}$, suggesting that the composite structure may stabilize the assemblies. Then, magnetic field oscillations at maximum amplitude of $10.2 \mathrm{kA} \mathrm{m}^{-1}$ and $755 \mathrm{kHz}$ were applied. Heat generated by the IONP-loaded micelles led to only a slight increase in temperature of $\sim 2{ }^{\circ} \mathrm{C}$ for the bulk suspension. Nevertheless, the MFH had a rapid effect on the magnetic micelles, leading to an increase in diameter and large decrease in the CR. Normally, 


\section{ChemComm}

a)
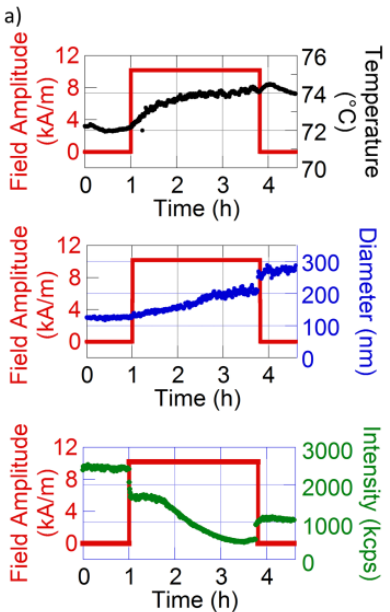

Fig. 4. Bulk temperature, particle diameter, and count rate measured before, during, and after magnetic hyperthermia using an in situ DLS for 35 mass\% IONP-loaded a) PEtG-DAPEG5000 micelles and b) Micelle-control

an increase in diameter would be expected to lead to an increase in CR. However, based on the experiments carried out on non-magnetic micelles, we hypothesize that upon application of $\mathrm{MFH}$, the polymer degraded, leading to an overall reduction of the concentration of scattering species and reduced CR. The resulting unstabilized hydrophobic IONPs then aggregated, resulting in an increased diameter. In the case of the control IONPloaded Micelle-control, a similar elevation of temperature was recorded, but diameters and intensities remained relatively constant. The experiment was also conducted at lower initial temperatures $\left(53^{\circ} \mathrm{C}\right)$ for the IONP-loaded thermo-responsive micelles but no significant changes were observed by DLS over the same time period (Fig. S41). Thus, while elevated initial temperatures were required for the MFH effect, these experiments demonstrate the ability to indirectly and selectively trigger the disassembly of the thermo-responsive micelles. A complementary small angle neutron scattering (SANS) study confirmed the thermo-induced degradation of the assemblies, both for pure and IONP-loaded PEtG-DA-PEG5000 micelles heated at $80{ }^{\circ} \mathrm{C}$ for 30 min (Fig. S42).

In conclusion, we showed that a simple DA adduct of a furan and maleimide could serve as a new thermo-responsive endcap for SIPs. It was readily functionalized to enable conjugation of PEG, forming block copolymers. Thermo-responsive PEtGPEO copolymers with different PEG weight fractions were prepared and self-assembled to form micelles or vesicles. These nanoassemblies were triggered to disassemble upon heating as demonstrated by TEM, DLS, release of nile red, and NMR spectroscopy. Furthermore, MFH was used as an indirect stimulus to trigger the degradation of IONP-loaded micelles. Future work will involve the tuning of the structures of the end-caps and the assemblies to enable them to respond to heat stimuli both directly and indirectly at lower temperatures.
The authors thank the Natural Sciences and Engineering Research Council of Canada (DG and SPG) and the Agence Nationale de la Recherche (ANR-13-BS08-0017) for funding.

\section{Notes and references}

1. S. Ganta, H. Devalapally, A. Shahiwala and M. Amiji, J. Controlled Release, 2008, 126, 187.

2. J. Ge, T. Huynh, Y. Hu and Y. Yin, Nano lett., 2008, 8, 931.

3. Y. Wang, A. S. Angelatos and F. Caruso, Chem. Mater., 2007, 20, 848 .

4. J. Zhuang, M. R. Gordon, J. Ventura, L. Li and S. Thayumanavan, Chem. Soc. Rev., 2013, 42, 7421.

5. J. S. Katz and J. A. Burdick, Macromol. Biosci., 2010, 10, 339. 6. W. Agut, A. Brûlet, C. Schatz, D. Taton and S. Lecommandoux, Langmuir, 2010, 26, 10546.

7. J. Liu, Y. Huang, A. Kumar, A. Tan, S. Jin, A. Mozhi and X. J. Liang, Biotechnol. Adv., 2014, 32, 693.

8. X. Huang, I. H. El-Sayed, W. Qian and M. A. El-Sayed, J. Am. Chem. Soc., 2006, 128, 2115.

9. G. Hemery, E. Garanger, S. Lecommandoux, A. D. Wong, E. R. Gillies, B. Pedrono, T. Bayle, D. Jacob and O. Sandre, J. Phys. D: Appl. Phys., 2015, 48, 494001.

10. S. Qin, Y. Geng, D. E. Discher and S. Yang, Adv. Mater., 2006, 18, 2905.

11. A. W. Jackson, D. A. Fulton, Polym. Chem. 2013, 4, 31.

12. M. E. Roth, O. Green, S. Gnaim and D. Shabat, Chem. Rev., 2015, 116, 1309.

13. A. Sagi, R. Weinstain, N. Karton and D. Shabat, J. Am. Chem. Soc., 2008, 130, 5434.

14. M. G. Olah, J. S. Robbins, M. S. Baker and S. T. Phillips, Macromolecules, 2013, 46, 5924.

15. B. Fan, J. F. Trant, A. D. Wong and E. R. Gillies, J. Am. Chem. Soc., 2014, 136, 10116.

16. A. M. DiLauro, A. Abbaspourrad, D. A. Weitz and S. T. Phillips, Macromolecules, 2013, 46, 3309.

17. A. W. Knoll, D. Pires, O. Coulembier, P. Dubois and J. L. Hedrick, Adv. Mater., 2010, 22, 3361.

18. B. Fan, J. F. Trant and E. R. Gillies, Macromolecules, 2016, 49, 9309.

19. G. Liu, X. Wang, J. Hu, G. Zhang and S. Liu, J. Am. Chem. Soc., 2014, 136, 7492.

20. G. Liu, G. Zhang, J. Hu, X. Wang, M. Zhu and S. Liu, J. Am. Chem. Soc., 2015, 137, 11645.

21. B. Fan and E. R. Gillies, Mol. Pharmaceutics, 2017, 14, 2548. 22. G. I. Peterson, D. C. Church, N. A. Yakelis and A. J. Boydston, Polymer, 2014, 55, 5980.

23. A. Gandini, Prog. Polym. Sci., 2013, 38, 1.

24. J. E. Zanetti and J. T. Bashour, J. Am. Chem. Soc., 1939, 61 2249.

25. B. Fan, J. F. Trant, R. E. Yardley, A. J. Pickering, F. LagugnéLabarthet and E. R. Gillies, Macromolecules, 2016, 49, 7196. 26. T. T. N'Guyen, H. T. Duong, J. Basuki, V. Montembault, S. Pascual, C. Guibert, J. Fresnais, C. Boyer, M. R. Whittaker and T. P. Davis, Angew. Chem., Int. Ed., 2013, 52, 14152.

27. W. Agut, A. Brûlet, D. Taton, O. Sandre and S. Lecommandoux, Soft Matter, 2011, 7, 9744.

\section{Acknowledgements}




\title{
Thermo-responsive self-immolative nanoassemblies: Direct and indirect triggering
}

\author{
Bo Fan ${ }^{1}$, John F. Trant ${ }^{2}$, Gauvin Hemery ${ }^{3}$, Olivier Sandre ${ }^{3}$, Elizabeth R. Gillies*1,2 \\ ${ }^{1}$ Department of Chemical and Biochemical Engineering, The University of Western Ontario, 1151 Richmond St., \\ London, Canada, N6A 5B9; E-mail: egillie@uwo.ca. \\ ${ }^{2}$ Department of Chemistry, The University of Western Ontario, 1151 Richmond Street, London, Canada, N6A 5B7. \\ ${ }^{3}$ Laboratoire de Chimie des Polymères Organiques (LCPO), Université de Bordeaux, Bordeaux INP, ENSCBP, 16 \\ avenue Pey Berland, Pessac Cedex, France, 33607.
}

\section{Table of Contents}

1. Chemical structures of control polymers .............................................

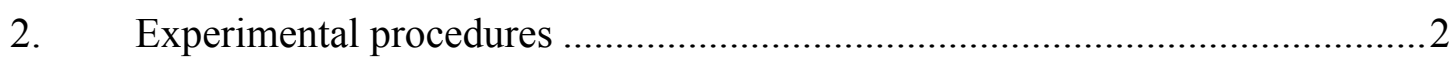

3. NMR Spectra of compounds and polymers ............................................ 13

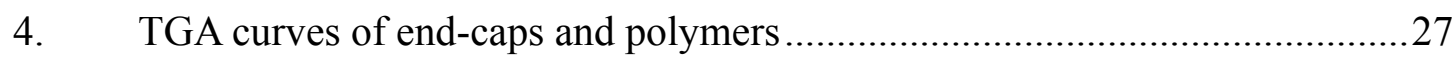

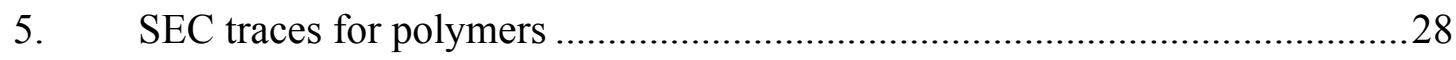

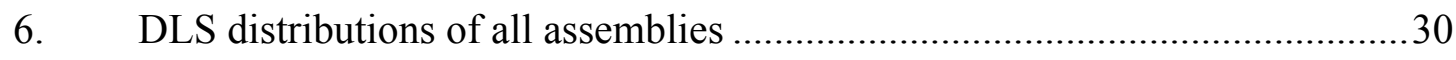

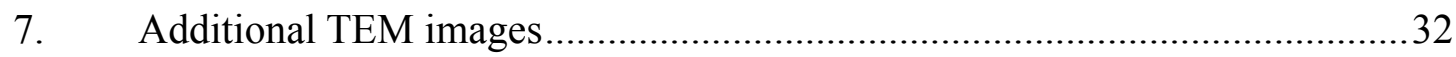

8. Study of the thermal degradation by small angle neutron scattering................34

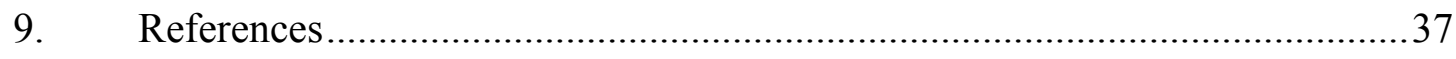




\section{Chemical structures of control polymers}

a)<smiles>CCOC(=O)C(OC(=O)OCc1ccccc1)OC(=O)OCc1ccccc1</smiles>

b)

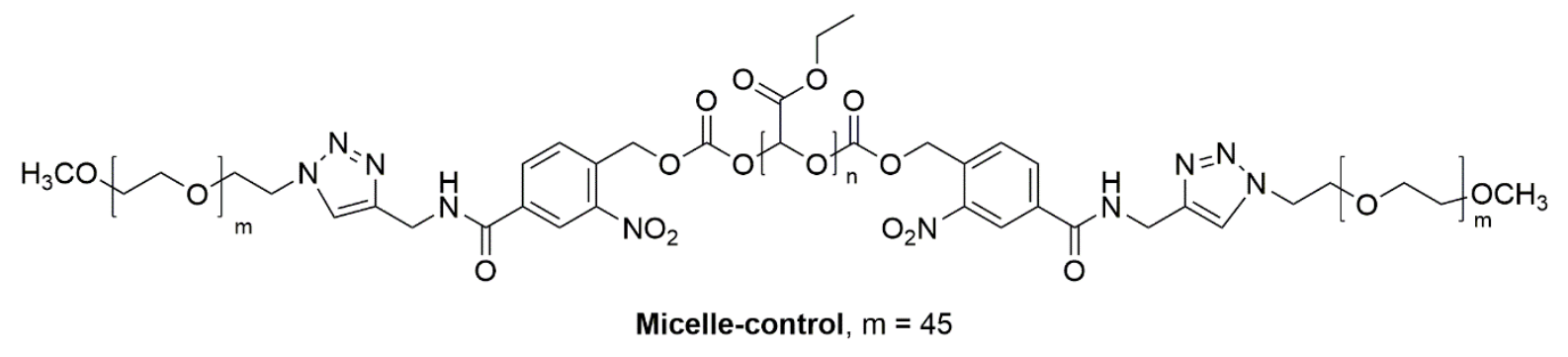

c)

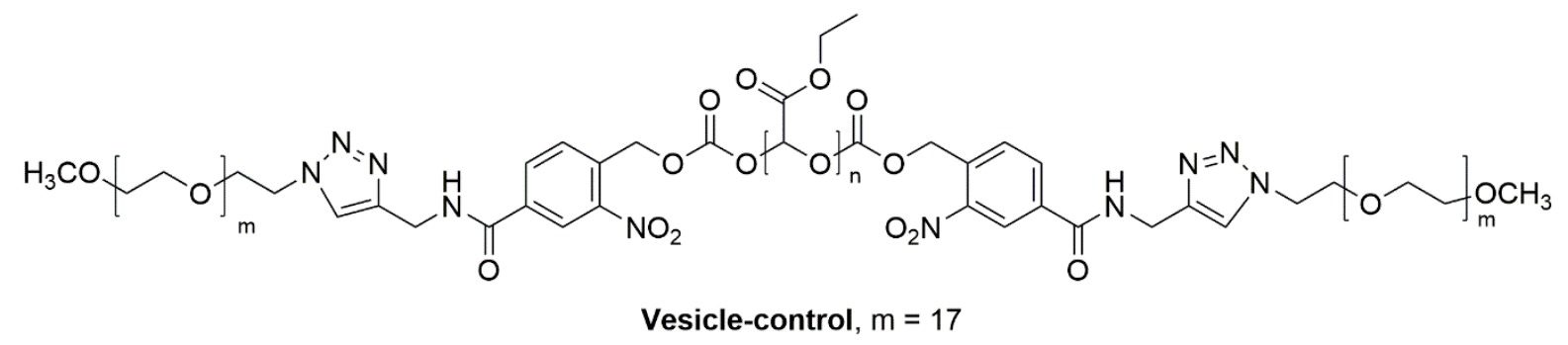

Scheme S1. Chemical structure of a) PEtG-control, b) Micelle-control, and c) Vesicle control.

\section{Experimental procedures}

General materials and procedures. Micelle-control ${ }^{1 \mathrm{a}}$ and PEtG-control ${ }^{1 \mathrm{~b}}$ were previously reported and the same batches were used here. Ethyl glyoxylate in toluene solution $(50 \% \mathrm{w} / \mathrm{w})$, 2-(hydroxymethyl)furan, diisopropylethylamine were obtained from Alfa Aesar (Canada). Nile red and phosgene solution (15 wt. \% in toluene) were purchased from Sigma-Aldrich (USA). Iron dichloride tetra-hydrate powder $\left(\mathrm{FeCl}_{2} \cdot 4 \mathrm{H}_{2} \mathrm{O}\right)$, iron trichloride hexahydrate $45 \%$ solution $\left(\mathrm{FeCl}_{3} \cdot 6 \mathrm{H}_{2} \mathrm{O}\right)$, diethylene glycol, $\mathrm{N}$-methyldiethanolamine, nitric acid were obtained from Sigma-Aldrich (France). Beycostat NE (Ref NB09) was obtained from CECA chemicals (France). Triethylamine, pyridine, and dichloromethane were distilled from calcium hydride before use. Anhydrous tetrahydrofuran, acetonitrile were obtained from a solvent purification 
system using aluminum oxide columns. All the other chemicals were of reagent grade and used without further purification. ${ }^{1} \mathrm{H}$ NMR spectra were obtained at $400 \mathrm{MHz}$ or $600 \mathrm{MHz}$ on Varian Inova instruments. NMR chemical shifts $(\delta)$ are reported in ppm and were calibrated against residual solvent signals of $\mathrm{CDCl}_{3}(\delta 7.27), \mathrm{CD}_{3} \mathrm{CN}(\delta 1.94)$, or $\mathrm{D}_{2} \mathrm{O}(\delta 4.75)$. Fourier transform infrared (FTIR) spectra were obtained in attenuated total reflectance (ATR) mode using a PerkinElmer UATR Spectrum Two with films drop cast from $\mathrm{CH}_{2} \mathrm{Cl}_{2}$ on diamond. High-resolution mass spectrometry (HRMS) was performed with either a Thermo Scientific DFS (Double Focus Sector) mass spectrometer, using a reversed Nier Johnson geometry for electron impact (EI) ionization, or a Bruker microOTOF 11 for electrospray ionization (ESI). The SEC instrument was equipped with a Viscotek GPC Max VE2001 solvent module. Samples were analyzed using the Viscotek VE3580 RI detector operating at $30{ }^{\circ} \mathrm{C}$. The separation technique employed two Agilent Polypore $(300 \times 7.5 \mathrm{~mm})$ columns connected in series and to a Polypore guard column $(50 \times 7.5 \mathrm{~mm})$. Samples were dissolved in THF (glass distilled grade) at approximately $5 \mathrm{mg} / \mathrm{mL}$ and filtered through $0.22 \mu \mathrm{m}$ syringe filters. Samples were injected using a $100 \mu \mathrm{L}$ loop. The THF eluent was filtered and eluted at $1 \mathrm{~mL} / \mathrm{min}$ for a total of $30 \mathrm{~min}$. A calibration curve was obtained from poly(methyl methacrylate) standards with molecular weight ranges of 1,540-1,126,000/mol. Thermogravimetric analyses (TGA) were performed on a TGA Q50 from TA Instruments. The heating rate was $10{ }^{\circ} \mathrm{C} / \mathrm{min}$ between $30-500{ }^{\circ} \mathrm{C}$ under $\mathrm{N}_{2}$. Ultrapure water was obtained from a Barnstead EASYpure II system. Dialyses were performed using Spectra/Por regenerated cellulose membranes with $3500 \mathrm{~g} / \mathrm{mol}$ molecular weight cut-off. The hydrodynamic diameters of the polymer assemblies were measured by dynamic light scattering (DLS) using a Zetasizer Nano Series ZS instrument from Malvern Instruments, at room temperature $\left(25^{\circ} \mathrm{C}\right)$ in a $1 \mathrm{~cm}$ path length glass cuvette at a concentration of $0.8 \mathrm{mg} / \mathrm{ml}$ suspension of polymer assemblies. Fluorescence spectra were obtained using a QM-4 SE spectrometer from Photon Technology International (PTI) equipped with double excitation and emission monochromators. TEM imaging was performed using a Phillips CM10 microscope operating at an acceleration voltage of $80 \mathrm{kV} .3 \mu \mathrm{L}$ of micelle suspension $(0.08 \mathrm{mg} / \mathrm{mL}) \mathrm{was}$ 
placed onto a copper grid. The resulting sample was air-dried overnight before imaging. TEM for IONPs and IONPs loaded micelles was performed on a Hitachi H7650 microscope operated at 80 $\mathrm{kV}$ on samples deposited at $\sim 1 \mathrm{mg} / \mathrm{mL}$ onto copper grids by a lab-made spraying tool.

Synthesis of Compound 3a. $N$-benzyl maleimide ${ }^{2}(2.00 \mathrm{~g}, 10.7 \mathrm{mmol})$ and 2-(hydroxymethyl) furan $(931 \mu \mathrm{L}, 1.05 \mathrm{~g}, 10.7 \mathrm{mmol})$ were dissolved in anhydrous acetonitrile under a nitrogen atmosphere in a flame-dried flask equipped with a magnetic stirring-bar. The reaction was stirred at $35^{\circ} \mathrm{C}$ for $14 \mathrm{~h}$. When TLC indicated the reaction had reached equilibrium, the solvent was removed, and the reaction was concentrated under reduced pressure for $1 \mathrm{~h}$. NMR spectroscopy of the unpurified reaction product indicated a ratio of (1:0.4:0.3) of endo-exo-unreacted maleimide. The crude material was then purified by flash chromatography (6:4 to 4:6 hexanes-ethyl acetate) to provide $2.3 \mathrm{~g}$ of a mixture of the endo and exo in a 70:30 ratio and a $75 \%$ isolated yield. A small amount of material was purified further by preparative TLC (8:2 hexanes-ethyl acetate, 7 elutions) to provide analytical samples of both the endo and exo products. Due to the inherent thermal instability, the material is stored at $-20^{\circ} \mathrm{C}$ until needed. 3a-endo ${ }^{1} \mathrm{H}$ NMR $\left(600 \mathrm{MHz}, \mathrm{CDCl}_{3}\right): \quad \delta_{\mathrm{ppm}} 7.31-7.26(\mathrm{~m}, 5 \mathrm{H}), 6.15(\mathrm{dd}, J=5.8,1.5 \mathrm{~Hz}, 1 \mathrm{H})$, $6.06(\mathrm{~d}, J=5.8 \mathrm{~Hz}, 1 \mathrm{H}), 5.26(\mathrm{dd}, J=5.5,1.6 \mathrm{~Hz}, 1 \mathrm{H}), 4.47(\mathrm{~s}, 2 \mathrm{H}), 4.25(\mathrm{~d}, J=12.2 \mathrm{~Hz}, 1 \mathrm{H})$, $4.15(\mathrm{~d}, J=12.2 \mathrm{~Hz}, 1 \mathrm{H}), 3.63$ (dd, $J=7.6,5.5 \mathrm{~Hz}, 1 \mathrm{H}), 3.40$ (d, $J=7.6 \mathrm{~Hz}, 1 \mathrm{H}), 2.11$ (s, 1H); ${ }^{13} \mathrm{C} \mathrm{NMR}\left(100 \mathrm{MHz}, \mathrm{CDCl}_{3}\right): \delta_{\mathrm{ppm}} 174.8,174.4,135.31,135.28,134.5,129.0,128.4,128.0,92.1$, 79.5, 61.4, 47.9, 46.0, 42.3; HRMS (ESI): Calc'd for [M] ${ }^{+}\left(\mathrm{C}_{16} \mathrm{H}_{15} \mathrm{NO}_{4}\right)$ : 285.1001; Found: 285.1012. 3a-exo ${ }^{1} \mathrm{H}$ NMR (600 MHz, $\left.\mathrm{CDCl}_{3}\right): \delta_{\mathrm{ppm}} 7.33-7.26(\mathrm{~m}, 5 \mathrm{H}), 6.61(\mathrm{~d}, J=5.7 \mathrm{~Hz}, 1 \mathrm{H})$, 6.54 (dd, $J=5.7,1.5 \mathrm{~Hz}, 1 \mathrm{H}), 5.28$ (d, $J=1.7 \mathrm{~Hz}, 1 \mathrm{H}), 4.66$ (s, 2H), 4.09 (dd, $J=12.2,8.8 \mathrm{~Hz}$, 1H), $4.03(\mathrm{dd}, J=12.2,6.3 \mathrm{~Hz}, 1 \mathrm{H}), 3.02(\mathrm{~d}, J=6.5 \mathrm{~Hz}, 1 \mathrm{H}), 2.99$ (d, $J=6.5 \mathrm{~Hz}, 1 \mathrm{H}), 2.76$ (bt, $J=7.4 \mathrm{~Hz}, 1 \mathrm{H}) ;{ }^{13} \mathrm{C} \mathrm{NMR}\left(100 \mathrm{MHz}, \mathrm{CDCl}_{3}\right): \delta_{\mathrm{ppm}} 175.7,175.6,138.3,136.9,135.2,128.6$, 128.0, 127.8, 91.4, 80.8, 60.7, 50.0, 48.1, 42.5; HRMS (ESI): Calc'd for [M] ${ }^{+}\left(\mathrm{C}_{16} \mathrm{H}_{15} \mathrm{NO}_{4}\right)$ : 285.1001; Found: 285.0993.

Synthesis of compound 4a. Compound 3a (500 mg, $1.75 \mathrm{mmol}, 1.0$ equiv.) was dissolved in 
THF $(10 \mathrm{~mL})$. The resulting solution was then added dropwise into a phosgene solution (15 wt $\%$ in toluene, $3.8 \mathrm{~mL}, 5.25 \mathrm{mmol}, 3.0$ equiv.) under an argon atmosphere at room temperature and was stirred for $24 \mathrm{~h}$. The residual phosgene and solvent were then removed under high vacuum to yield chloroformate 4a (590 mg, 97\%) as white gel. Phosgene collected in the liquid nitrogen-cooled trap was then quenched with methanol $(20 \mathrm{~mL})$ and saturated sodium hydroxide solution $(20 \mathrm{~mL})$. Caution! Phosgene is highly toxic. ${ }^{1} \mathrm{H}$ NMR $\left(400 \mathrm{MHz}, \mathrm{CDCl}_{3}\right): \delta_{\mathrm{ppm}}$ 7.33-7.19 (m, 5H), $6.59(\mathrm{dd}, J=5.5,1.2 \mathrm{~Hz}, 2 \mathrm{H}), 6.44(\mathrm{~d}, J=5.5 \mathrm{~Hz}, 2 \mathrm{H}), 6.15(\mathrm{dd}, J=5.9,1.6$ $\mathrm{Hz}, 1 \mathrm{H}), 5.98(\mathrm{~d}, J=5.9 \mathrm{~Hz}, 1 \mathrm{H}), 5.29(\mathrm{~d}, J=1.6 \mathrm{~Hz}, 2 \mathrm{H}), 5.26(\mathrm{dd}, J=5.5,1.6 \mathrm{~Hz}, 1 \mathrm{H})$, 5.03-4.94 (m, 3H), 4.80-4.68 (m, 3H) $4.62(\mathrm{~s}, 4 \mathrm{H}), 4.44(\mathrm{~s}, 2 \mathrm{H}), 3.63(\mathrm{dd}, J=7.8,5.5 \mathrm{~Hz}, 1 \mathrm{H})$, $3.34(\mathrm{~d}, J=7.8 \mathrm{~Hz}, 1 \mathrm{H}), 2.99-2.89(\mathrm{~m}, 4 \mathrm{H}) ;{ }^{13} \mathrm{C} \mathrm{NMR}\left(100 \mathrm{MHz}, \mathrm{CDCl}_{3}\right): \delta_{\mathrm{ppm}} 174.9,173.6$, $150.5,138.0,135.9,135.0,128.9,128.6,127.9,127.8,125.2,88.8,81.2,49.7,48.4,46.2,42.3$; HRMS (EI) calc'd. for [M] ${ }^{+}\left(\mathrm{C}_{17} \mathrm{H}_{14} \mathrm{ClNO}_{5}\right)$ : 347.0561 ; Found: 347.0573.

Synthesis of compound 3b. $N$-propargyl maleimide ${ }^{3}$ (1.70 g, 12.6 mmol, 1.0 equiv.) and 2-(hydroxymethyl)furan (1.1 mL, $1.24 \mathrm{~g}, 12.6 \mathrm{mmol}, 1.0$ equiv.) were dissolved in anhydrous acetonitrile $(10 \mathrm{~mL})$ under a nitrogen atmosphere in a flame-dried flask equipped with a magnetic stirring-bar. The reaction was stirred at $35^{\circ} \mathrm{C}$ for 14 hours. When TLC indicated the reaction had reached equilibrium, the solvent was removed, and the reaction was concentrated under reduced pressure for $1 \mathrm{~h}$. NMR spectroscopy of the unpurified product indicated a ratio of (3.7:0.7:1.0) of endo-exo-unreacted maleimide. The crude material was then purified by flash chromatography (1:1 to 4:6 hexanes-ethyl acetate) to provide $2.09 \mathrm{~g}$ of a mixture of the endo and exo in an 80:20 ratio and a $72 \%$ isolated yield. A small amount of material was purified further by preparative TLC (7:3 hexanes-ethyl acetate, 4 elutions) to provide analytical samples of both the endo and exo products. Due to the inherent thermal instability, the material is stored at $-20{ }^{\circ} \mathrm{C}$ until needed. 3b-endo ${ }^{1} \mathrm{H} \mathrm{NMR}\left(600 \mathrm{MHz}, \mathrm{CDCl}_{3}\right): \quad \delta_{\mathrm{ppm}} 6.43(\mathrm{dd}, J=5.8,1.6 \mathrm{~Hz}, 1 \mathrm{H}), 6.31$ $(\mathrm{d}, J=5.8 \mathrm{~Hz}, 1 \mathrm{H}), 5.31(\mathrm{dd}, J=5.5,1.6 \mathrm{~Hz}, 1 \mathrm{H}), 4.26(\mathrm{~d}, J=12.8 \mathrm{~Hz}, 1 \mathrm{H}), 4.17(\mathrm{~d}, J=12.8$ $\mathrm{Hz}, 1 \mathrm{H}), 4.06(\mathrm{~d}, J=2.5 \mathrm{~Hz}, 2 \mathrm{H}), 3.67(\mathrm{dd}, J=7.6,5.5 \mathrm{~Hz}, 1 \mathrm{H}), 3.48(\mathrm{~d}, J=7.6 \mathrm{~Hz}, 1 \mathrm{H}), 2.16$ $(\mathrm{t}, J=2.5 \mathrm{~Hz}, 1 \mathrm{H}), 2.10(\mathrm{bs}, 1 \mathrm{H}) ;{ }^{13} \mathrm{C} \mathrm{NMR}\left(100 \mathrm{MHz}, \mathrm{CDCl}_{3}\right): \delta_{\mathrm{ppm}} 173.8,173.4,135.6,134.7$, 
92.3, 79.7, 76.0, 71.4, 61.4, 50.1, 48.2, 27.6; HRMS (ESI): Calc'd for [M] ${ }^{+}\left(\mathrm{C}_{12} \mathrm{H}_{11} \mathrm{NO}_{4}\right)$ : 233.0688. Found: 233.06824 . 3b-exo ${ }^{1} \mathrm{H}$ NMR $\left(400 \mathrm{MHz}, \mathrm{CDCl}_{3}\right): \delta_{\mathrm{ppm}} 6.62(\mathrm{~d}, J=5.7 \mathrm{~Hz}, 1 \mathrm{H})$, $6.55(\mathrm{dd}, J=5.7,1.6 \mathrm{~Hz}, 1 \mathrm{H}), 5.29(\mathrm{~d}, J=1.7 \mathrm{~Hz}, 1 \mathrm{H}), 4.25(\mathrm{~d}, J=2.5 \mathrm{~Hz}, 2 \mathrm{H}), 4.10(\mathrm{~d}, J=1.8$ $\mathrm{Hz}, 2 \mathrm{H}), 3.68(\mathrm{dd}, J=7.6,5.5 \mathrm{~Hz}, 1 \mathrm{H}), 3.48(\mathrm{~d}, J=7.6 \mathrm{~Hz}, 1 \mathrm{H}), 2.21(\mathrm{t}, J=2.5,2.5 \mathrm{~Hz}, 1 \mathrm{H})$, 1.64 (bs, $1 \mathrm{H}) ;{ }^{13} \mathrm{C}$ NMR $\left(100 \mathrm{MHz}, \mathrm{CDCl}_{3}\right): \delta_{\mathrm{ppm}} 174.5,174.4,138.3,137.0,91.5,80.9,76.2$, 71.7, 60.5, 50.1, 48.1, 27.9; ESI (MS): Calc'd for $[\mathrm{M}]^{+}\left(\mathrm{C}_{12} \mathrm{H}_{11} \mathrm{NO}_{4}\right)$ : 233.0688; Found: 233.06892 .

Synthesis of compound $4 \mathbf{b}$. Compound $\mathbf{3 b}(500 \mathrm{mg}, 2.15 \mathrm{mmol}, 1.0$ equiv.) was dissolved in THF $(10 \mathrm{~mL})$. The resulting solution was then added dropwise into a phosgene solution (15 wt $\%$ in toluene, $4.6 \mathrm{~mL}, 6.44 \mathrm{mmol}, 3.0$ equiv.) under an argon atmosphere at room temperature and was stirred for $24 \mathrm{~h}$. The residual phosgene and solvent were then removed by high vacuum to yield chloroformate $4 \mathbf{b}$ (610 mg, 97\%) as a white gel. Phosgene collected in the liquid nitrogen-cooled trap was then quenched with methanol $(20 \mathrm{~mL})$ and saturated sodium hydroxide

solution $(20 \mathrm{~mL})$. Caution! Phosgene is highly toxic. ${ }^{1} \mathrm{H} \mathrm{NMR}\left(600 \mathrm{MHz}, \mathrm{CDCl}_{3}\right): \delta_{\mathrm{ppm}} 6.66(\mathrm{~d}$, $J=5.3 \mathrm{~Hz}, 2 \mathrm{H}), 6.53(\mathrm{~d}, J=5.3 \mathrm{~Hz}, 1 \mathrm{H}), 6.50(\mathrm{~d}, J=5.9 \mathrm{~Hz}, 2 \mathrm{H}), 6.34(\mathrm{~d}, J=5.9 \mathrm{~Hz}, 1 \mathrm{H})$, $5.39(\mathrm{~d}, J=4.1 \mathrm{~Hz}, 1 \mathrm{H}), 5.35(\mathrm{~s}, 2 \mathrm{H}), 5.09-5.05(\mathrm{~m}, 3 \mathrm{H}), 4.88(\mathrm{~d}, J=12.3 \mathrm{~Hz}, 1 \mathrm{H}), 4.78(\mathrm{~d}, J$ $=12.9 \mathrm{~Hz}, 2 \mathrm{H}), 4.25(\mathrm{~d}, J=2.9 \mathrm{~Hz}, 4 \mathrm{H}), 4.11(\mathrm{~d}, J=2.4 \mathrm{~Hz}, 3 \mathrm{H}), 3.73(\mathrm{dd}, J=5.3,2.4 \mathrm{~Hz}$, 1H), 3.46 (d, $J=7.6 \mathrm{~Hz}, 1 \mathrm{H}), 3.08$ (d, $J=6.5 \mathrm{~Hz}, 2 \mathrm{H}), 3.00$ (d, $J=6.5 \mathrm{~Hz}, 2 \mathrm{H}), 2.21$ (t, $J=$ $2.4 \mathrm{~Hz}, 1 \mathrm{H}), 2.19(\mathrm{t}, J=2.4 \mathrm{~Hz}, 1 \mathrm{H}) ;{ }^{13} \mathrm{C} \mathrm{NMR}\left(150 \mathrm{MHz}, \mathrm{CDCl}_{3}\right): \delta_{\mathrm{ppm}} 174.0,172.8,150.9$, 138.4, 136.4, 133.7, 129.2, 128.4, 125.5, 89.3, 81.5, 76.2, 71.9, 68.1, 50.2, 48.8, 46.7, 28.3, 27.9; HRMS (EI) calc'd. for [M] ${ }^{+} \mathrm{C}_{13} \mathrm{H}_{10} \mathrm{ClNO}_{5}$ : 295.0248; Found: 295.0257.

\section{Synthesis of PEtG-DA-Bn and typical procedure for synthesis of end-capped PEtG. Ethyl}

glyoxylate in toluene solution $(20.0 \mathrm{~mL})$ was distilled under vacuum $\left(25{ }^{\circ} \mathrm{C}, 0.3 \mathrm{mbar}\right)$ over $\mathrm{P}_{2} \mathrm{O}_{5}$ to remove toluene and trace water in the first, discarded fraction. The residue was then distilled twice successively over $\mathrm{P}_{2} \mathrm{O}_{5}$ at atmospheric pressure under argon at $130{ }^{\circ} \mathrm{C}$ to obtain the highly pure monomer. Purified ethyl glyoxylate (2.0 mL, $20 \mathrm{mmol}$, 1.0 equiv.) was dissolved in $\mathrm{CH}_{2} \mathrm{Cl}_{2}$ $(2.0 \mathrm{~mL})$ and $\mathrm{Et}_{3} \mathrm{~N}(1.4 \mu \mathrm{L}, 10 \mu \mathrm{mol}, 0.0005$ equiv.) was added. The solution was stirred for $1 \mathrm{~h}$ at 
$-20{ }^{\circ} \mathrm{C}$. Compound $4 \mathrm{a}\left(0.1 \mathrm{~g}, 280 \mu \mathrm{mol}, 0.014\right.$ equiv.) and $\mathrm{Et}_{3} \mathrm{~N}(38 \mu \mathrm{L}, 280 \mu \mathrm{mol}, 0.014$ equiv. $)$ were added at $-20^{\circ} \mathrm{C}$ to end-cap the polymer. The solution was gradually warmed to room temperature and then stirred for $16 \mathrm{~h}$. Purification was achieved by precipitation of the crude reaction mixture into methanol. After decanting the excess methanol, the residue was dried in vacuo to provide $1.1 \mathrm{~g}$ of a white, sticky polymer in $55 \%$ yield. ${ }^{1} \mathrm{H}$ NMR $\left(600 \mathrm{MHz}, \mathrm{CDCl}_{3}\right): \delta$ 7.28-7.32 (m, 10 H), 5.48-5.73 (m, 239 H), 4.15-4.31 (m, 449 H), 1.23-1.36 (m, 658 H). FT-IR: $2985,1748,1468,1447,1376,1297,1214,1137,1094,1015,989,856,675 \mathrm{~cm}^{-1}$. SEC: $\mathrm{M}_{\mathrm{n}}=33$ $\mathrm{kg} / \mathrm{mol}, \mathrm{M}_{\mathrm{w}}=59 \mathrm{~kg} / \mathrm{mol}, \oslash=1.8$.

Synthesis of PEtG-DA-alkyne. The polymer is synthesized by the same procedure described for PEtG-DA-Bn except that compound $\mathbf{4 b}$ was used as the end-cap. The yield was $60 \%$. ${ }^{1} \mathrm{H}$ NMR (600 MHz, $\left.\mathrm{CDCl}_{3}\right): \delta 5.47-5.76(\mathrm{~m}, 630 \mathrm{H}), 4.14-4.29(\mathrm{~m}, 1184 \mathrm{H}), 1.24-1.40(\mathrm{~m}, 1754 \mathrm{H})$. FTIR: $2985,1748,1468,1447,1376,1297,1214,1138,1094,1016,962,857,675 \mathrm{~cm}^{-1}$. SEC: $\mathrm{M}_{\mathrm{n}}=63$ $\mathrm{kg} / \mathrm{mol}, \mathrm{M}_{\mathrm{w}}=130 \mathrm{~kg} / \mathrm{mol}, \oslash=2.0$.

Synthesis of Block Copolymer PEtG-DA-PEG750. 750 g/mol PEG-N ${ }_{3}(36.0$ mg, $48 \mu \mathrm{mol}, 6$ equiv.) and PEtG-DA-alkyne (500.0 mg, $8 \mu \mathrm{mol}, 1$ equiv.) were dissolved in DMF (5.0 mL). After removing the air and refilling with argon, $\mathrm{CuSO}_{4}(4.0 \mathrm{mg}, 28 \mu \mathrm{mol}, 3.5$ equiv. $)$ and sodium ascorbate ( $5.0 \mathrm{mg}, 28 \mu \mathrm{mol}, 3.5$ equiv.) were added into the solution, and the mixture was stirred at $40{ }^{\circ} \mathrm{C}$ for $16 \mathrm{~h}$. The reaction mixture was then transferred into a regenerated cellulose membrane (50 kg/mol MWCO) and dialyzed against deionized water for $16 \mathrm{~h}(1 \mathrm{~L}, 2$ solvent changes) to remove DMF and most free PEG. The dialyzed material was then lyophilized, washed 3 times with water to further remove free PEG, and then dried to afford $500 \mathrm{mg}$ of the product as a white, rubber-like, polymer in $98 \%$ yield. ${ }^{1} \mathrm{H}$ NMR (600 MHz, $\left.\mathrm{CDCl}_{3}\right): \delta 5.47-5.75$ (m, $341 \mathrm{H}), 4.07-4.33(\mathrm{~m}, 704 \mathrm{H}), 3.63(\mathrm{~s}, 136 \mathrm{H}), 3.37$ (s, $6 \mathrm{H}), 1.13-1.42(\mathrm{~m}, 1075 \mathrm{H}) .{ }^{13} \mathrm{C}$ NMR (150 MHz, $\left.\mathrm{CDCl}_{3}\right): \delta$ 164.7-166.3, 90.3-94.7, 70.7, 62.3, 14. FTIR: 2985, 1750, 1468, $1447,1376,1298,1216,1138,1017,1095,964,857,677 \mathrm{~cm}^{-1}$. SEC: $\mathrm{M}_{\mathrm{n}}=59 \mathrm{~kg} / \mathrm{mol}, \mathrm{M}_{\mathrm{w}}=111$ $\mathrm{kg} / \mathrm{mol}, \nexists=1.9$. 
Synthesis of PEtG-DA-PEG5000. The polymer was synthesized by the same procedure described above for the synthesis of PEtG-DA-PEG750, except that $5000 \mathrm{~g} / \mathrm{mol} \mathrm{PEG-N}$ was used. The yield was $98 \%$. ${ }^{1} \mathrm{H}$ NMR $\left(600 \mathrm{MHz} \mathrm{CDCl}_{3}\right): \delta 5.45-5.70(\mathrm{~m}, 670 \mathrm{H}), 4.10-4.30(\mathrm{~m}$, $1399 \mathrm{H}), 3.62(\mathrm{~s}, 909 \mathrm{H}), 3.36(\mathrm{~s}, 3 \mathrm{H}), 1.20-1.34(\mathrm{~m}, 2110 \mathrm{H}) .{ }^{13} \mathrm{C} \mathrm{NMR}\left(150 \mathrm{MHz}, \mathrm{CDCl}_{3}\right): \delta$ 164.6-166.7, 90.8-93.9, 70.5, 62.0, 13.8. FT-IR (thin film): 2985, 2874, 1750, 1468, 1448, 1376, $1298,1216,1136,1095,1018,962,856,680 \mathrm{~cm}^{-1} . \mathrm{SEC}: \mathrm{M}_{\mathrm{n}}=35 \mathrm{~kg} / \mathrm{mol}, \mathrm{M}_{\mathrm{w}}=71 \mathrm{~kg} / \mathrm{mol}, Ð=$ 2.0.

Synthesis of Vesicle-control. The polymer was synthesized by the same procedure as Micelle-control $^{1 \mathbf{a}}$, except that $750 \mathrm{~g} / \mathrm{mol}$ PEG-N 3 was used. The yield was $86 \%$. ${ }^{1} \mathrm{H}$ NMR (600 $\left.\mathrm{MHz}, \mathrm{CDCl}_{3}\right): \delta 5.47-5.77(\mathrm{~m}, 553 \mathrm{H}), 4.07-4.36(\mathrm{~m}, 1040 \mathrm{H}), 3.65(\mathrm{~s}, 136 \mathrm{H}), 3.39(\mathrm{~s}, 9 \mathrm{H})$, 1.13-1.47 (m, $1573 \mathrm{H}) .{ }^{13} \mathrm{C}$ NMR (150 MHz, $\left.\mathrm{CDCl}_{3}\right): \delta 164.0-166.5,90.0-94.2,70.5,62.0,13.8$. FT-IR (thin film): 2985, 2874, 1752, 1467, 1448, 1376, 1297, 1217, 1140, 1096, 1018, 965, 855, $732 \mathrm{~cm}^{-1}$. SEC: $\mathrm{M}_{\mathrm{n}}=77 \mathrm{~kg} / \mathrm{mol}, \mathrm{M}_{\mathrm{w}}=177 \mathrm{~kg} / \mathrm{mol}, Ð=2.3$.

\section{Study of PEtG-DA-Bn Depolymerization in Solution and Representative Procedure for} Studying Depolymerization by NMR Spectroscopy. PEtG-DA-Bn (15.0 mg) was dissolved in a 9:1 mixture of $\mathrm{CD}_{3} \mathrm{CN}$ : $\mathrm{D}_{2} \mathrm{O}(1.2 \mathrm{~mL})$ at ambient temperature $\left(22{ }^{\circ} \mathrm{C}\right)$. The solution was then divided between two NMR tubes. One tube was incubated at $75{ }^{\circ} \mathrm{C}$ in an oven, while the other one was stored at room temperature $\left(22{ }^{\circ} \mathrm{C}\right) .{ }^{1} \mathrm{H}$ NMR spectra were recorded at defined intervals to monitor the depolymerization of the materials. At the same time, benzyl chloroformate end-capped PEtG (PEtG-control) ${ }^{1 \mathrm{~b}}$ was also subjected to the same procedure and its depolymerization was monitored by NMR spectroscopy as non-triggerable control. The extent of depolymerization was calculated as $\%$ depolymerization $=100-\mathrm{x}$, where $\mathrm{x}$ is the integration of the peak at $5.5 \mathrm{ppm}$, when the integration of the peak at $4.2 \mathrm{ppm}$ was set to 200 (which remained constant as it corresponds to the $\mathrm{CH}_{3} \underline{\mathrm{CH}}_{2} \mathrm{O}$ - in both polymer and the depolymerization product).

Self-assembly of PEtG-PEG Block Copolymers. $8.0 \mathrm{mg}$ of block copolymer was fully dissolved in $1.0 \mathrm{~mL}$ of organic solvent by stirring overnight (THF for PEtG-DA-PEG750 and 
Vesicle-control and DMSO for PEtG-DA-PEG5000 and Micelle-control). For vesicles, $0.9 \mathrm{~mL}$ deionized water was added slowly into $0.1 \mathrm{~mL}$ of copolymer in THF with gentle stirring. For micelles, $0.1 \mathrm{~mL}$ of the copolymer in DMSO was injected quickly into $0.9 \mathrm{~mL}$ of rapidly stirring deionized water. After stirring for 10 minutes, the suspension was then dialyzed against deionized water for $16 \mathrm{~h}$ (1 L, 2 solvent changes) to remove THF or DMSO, affording an aqueous suspension of assemblies.

Study of Assembly Decomposition by DLS. The assemblies were formed by the procedure described above, except that the assemblies suspension was dialyzed against $100 \mathrm{mM}$ pH 7.4 phosphate buffer solution. The assemblies were then transferred into plastic cuvettes and the CR was measured by DLS while fixing the attenuator. Samples were then incubated either at $75{ }^{\circ} \mathrm{C}$ in an oven or at room temperature $\left(22{ }^{\circ} \mathrm{C}\right)$. CR changes were recorded at defined intervals to monitor the decomposition of assemblies.

\section{Study of Nile Red Release.}

A stock of copolymer assembly solution at a concentration of $0.8 \mathrm{mg} / \mathrm{mL}$ was prepared by the above standard self-assembly procedure in $\mathrm{pH} 7.4$ phosphate buffer. $29 \mu \mathrm{L}$ of a $0.1 \mathrm{mg} / \mathrm{mL}$ solution of Nile red in $\mathrm{CH}_{2} \mathrm{Cl}_{2}$ was added to each of a series of vials and then the solvent was evaporated to provide a thin film of Nile red. To each vial, $1.5 \mathrm{~mL}$ of assembly suspension was added, and the vials were gently shaken for $16 \mathrm{~h}$ to incorporate Nile red into the nanoparticles. After the initial fluorescence emission $(600 \mathrm{~nm})$ of the micelle suspension was measured using an excitation wavelength of $540 \mathrm{~nm}$. Some samples were stored in an oven at $75{ }^{\circ} \mathrm{C}$, with others were stored at room temperature $\left(22{ }^{\circ} \mathrm{C}\right)$. The fluorescence emission was recorded at defined intervals to monitor the decomposition of assemblies.

Study of Assembly Depolymerization by ${ }^{1} \mathbf{H}$ NMR Spectroscopy. $10.0 \mathrm{mg}$ of block copolymer was fully dissolved in $0.4 \mathrm{~mL}$ of DMSO- $d_{6} .0 .2 \mathrm{~mL}$ of the resulting solution was rapidly injected into $1.0 \mathrm{~mL}$ of $100 \mathrm{mM}$, pH 7.4 phosphate buffered $\mathrm{D}_{2} \mathrm{O}$. After stirring for $10 \mathrm{~min}$, the micelle suspension was divided between two NMR tubes. One tube was incubated in an oven at $75{ }^{\circ} \mathrm{C}$, 
while the other one was kept at room temperature. ${ }^{1} \mathrm{H}$ NMR spectra were recorded at defined intervals to monitor the depolymerization of the materials. At the same time, Micelle-control was subjected to the same procedure. Percent depolymerization was determined using the sum of the integration of the methyl peaks corresponding to EtGH and ethanol (1.0-1.2 ppm), which plateaued at a very similar (1872) value to that of the methyl peak at 1.17-1.45 ppm in the block copolymer taken in $\mathrm{CDCl}_{3}$ (integration 2111) when setting the PEG peak integral to 909 . The \% polymer remaining was calculated as 100 - (sum of integration from 1.0-1.2 ppm/1872))×100.

"Polyol" Synthesis of Iron Oxide Nanoparticles" $1.082 \mathrm{~g}(4.0 \mathrm{mmol})$ of $\mathrm{FeCl}_{3} \cdot 6 \mathrm{H}_{2} \mathrm{O}$ and 398 $\mathrm{mg}(2.0 \mathrm{mmol})$ of $\mathrm{FeCl}_{2} .4 \mathrm{H}_{2} \mathrm{O}$ were dissolved in a mixture of $40 \mathrm{~g}$ of di(ethylene glycol) (DEG) and $40 \mathrm{~g}$ of $\mathrm{N}$-methyldiethanolamine (NMDEA). Meanwhile, $640 \mathrm{mg}$ (16 mmol) of $\mathrm{NaOH}$ was dissolved in a mixture of $20 \mathrm{~g}$ of DEG and $20 \mathrm{~g}$ of NMDEA. Both solutions were stirred overnight under nitrogen flux to prevent the oxidation of $\mathrm{Fe}^{2+}$ species. The solutions were then mixed and stirred for $3 \mathrm{~h}$, before heating the mixture to $210{ }^{\circ} \mathrm{C}$ with an oil bath, reflux set-up and mechanical agitation. The set-up was open and a flux of nitrogen helped to remove traces of water before temperature reaches $210{ }^{\circ} \mathrm{C}$. Once a temperature of $210{ }^{\circ} \mathrm{C}$ was reached, the set-up was closed, and $1 \mathrm{~mL}$ of water was injected in the system with a syringe through a septum, leading to a burst of nuclei. The formation of nanoparticles was carried on for $30 \mathrm{~min}$, then the system was cooled to room temperature. The black sediment was separated magnetically and washed with a mixture of ethanol and ethyl acetate $(1: 1 \mathrm{v} / \mathrm{v}) 3$ times. Possible iron hydroxides were removed by treatment with $10 \%$ nitric acid. The nanoparticles were then washed 2 times with acetone and 2 times with diethyl ether before being dispersed in water.

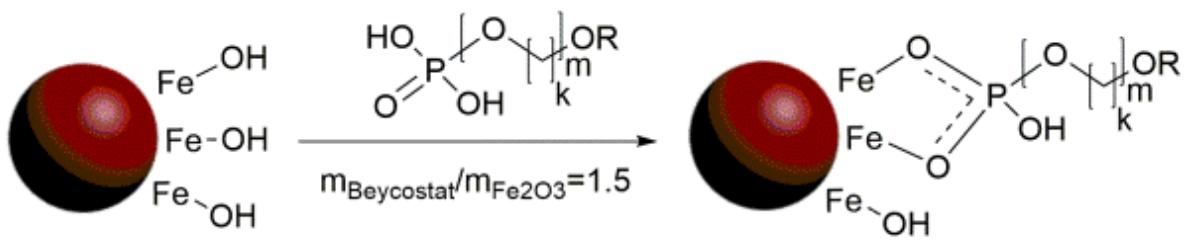

Scheme S2. Coating of IONPs. 
Coating of IONPs. $113 \mathrm{mg}$ of Beycostat NE was deposited in a $50 \mathrm{~mL}$ beaker. $15.0 \mathrm{~mL}$ of water was added and the solution was stirred with a mechanical agitator. $2.5 \mathrm{~mL}$ of a ferrofluid with an iron oxide concentration of $18.0 \mathrm{~g} / \mathrm{L}$ (45 $\mathrm{mg}$ of iron oxide in solution) was added to the surfactant. Then $2.6 \mathrm{~mL}$ of a $69 \% \mathrm{w} / \mathrm{w} \mathrm{HNO}_{3}$ solution was added to reach a final $\mathrm{HNO}_{3}$ concentration of $2.0 \mathrm{M}$. The solution was heated to $60{ }^{\circ} \mathrm{C}$ for $30 \mathrm{~min}$ with a water bath. The nanoparticles were then sedimented over a permanent magnet and washed 3 times with $50 \mathrm{~mL}$ of methanol, before being dispersed in $45 \mathrm{~mL}$ of dichloromethane or tetrahydrofuran (THF). The iron oxide content of this dispersion was estimated by dissolving 50.0 microliters of solution in $5.0 \mathrm{~mL}$ of $5.0 \mathrm{M} \mathrm{HCl} \mathrm{M}$ with the help of a sonication bath. The absorption at $350 \mathrm{~nm}$ correspondng to the peak of the $\left[\mathrm{Fe}(\mathrm{Cl})_{6}\right]^{3-}$ complex was compared to a calibration curve. The final concentration was estimated at $6.0 \mathrm{~g} / \mathrm{L}$ of $\mathrm{Fe}_{2} \mathrm{O}_{3}$.

\section{Loading of IONPs into Micelles. $1.0 \mathrm{mg}$ of PEtG-DA-PEG5000 or Micelle-control was} dissolved in $0.2 \mathrm{~mL}$ of THF, meanwhile IONPs (dispersed in THF with a concentration of 6.0 $\mathrm{mg} / \mathrm{mL}$ ) were mixed at different feed weight ratios (FWR) as needed with the polymer solution. This mixture was then added dropwise to $1.8 \mathrm{~mL}$ water via a micro-syringe while magnetically stirring. THF was allowed to evaporate by leaving the vials open for $24 \mathrm{~h}$.

Dynamic Light Scattering Coupled with Magnetic Field Hyperthermia. The combined DLS-MFH set-up based on a remote DLS setup VASCO Flex ${ }^{\mathrm{TM}}$ from Cordouan Technologies (Pessac, France) has been previously reported ${ }^{5}$ and is shown in Fig. S40. Micelles loaded with 35 mass \% IONPs were studied by DLS-MFH. The sample was heated up to the desired external temperature by a water bath. The temperature of the sample was measured with an optical fiber probe. After $1 \mathrm{~h}$ equilibration at the target temperature, the alternating magnetic field was applied at the maximum available amplitude of $10.2 \mathrm{kA} / \mathrm{m}$ and frequency of $755 \mathrm{kHz}$. Meanwhile, DLS was operating continuously at a backscattering angle of $165^{\circ}$ to measure the sample diameter (Z-average), polydispersity index (PDI) and signal intensity changes during this period.

Small angle neutron scattering (SANS) experiments were performed at the Orphée neutron 
facility of LLB-CEA (Saclay, France) on the PAXY spectrometer equipped with a 2D (anisotropic SANS) detector. Micelles were suspended at a concentration of $0.6 \mathrm{mg} \cdot \mathrm{mL}^{-1}$ in pure $\mathrm{D}_{2} \mathrm{O}$, of neutron scattering length density $\operatorname{SLD}\left(\mathrm{D}_{2} \mathrm{O}\right)=6.40 \times 10^{-6} \AA^{-2}$. The calculated SLD of iron oxide and ethyl glyoxylate monomer are $\operatorname{SLD}\left(\gamma-\mathrm{Fe}_{2} \mathrm{O}_{3}\right)=6.98 \times 10^{-6} \AA^{-2}$ and $\operatorname{SLD}(\mathrm{EtG})=1.31 \times 10^{-6}$ $\AA^{-2}$, respectively. The neutron scattering contrast of the micelles in heavy water thus arises almost exclusively from the hydrophobic Poly(EtG) block of the polymer, the hydrophilic PEG block being highly hydrated, thus having negligible contribution to the neutron scattering contrast. Three beamline configurations were used to cover overlapping scattering vector $(q)$ ranges of $1.92 \times 10^{-3}-2.84 \times 10^{-2}, 1.05 \times 10^{-2}-0.154$, and $3.19 \times 10^{-2}-0.427 \AA^{-1}$, with the following values of sample-to-detector distance $\mathrm{D}$ and neutron wavelength $\lambda$ : $\mathrm{D}=7 \mathrm{~m}$ and $\lambda=15 \AA$, $\mathrm{D}=3 \mathrm{~m}$ and $\lambda=6 \AA, \mathrm{D}=1 \mathrm{~m}$ and $\lambda=6 \AA$. The scattering intensity curves were divided by the transmission factor and subtracted from the incoherent background, before normalizing by the flat signal of a cuvette filled with light water to correct the detector efficiency, yielding the absolute intensity in $\mathrm{cm}^{-1}$. 


\section{NMR Spectra of compounds and polymers}

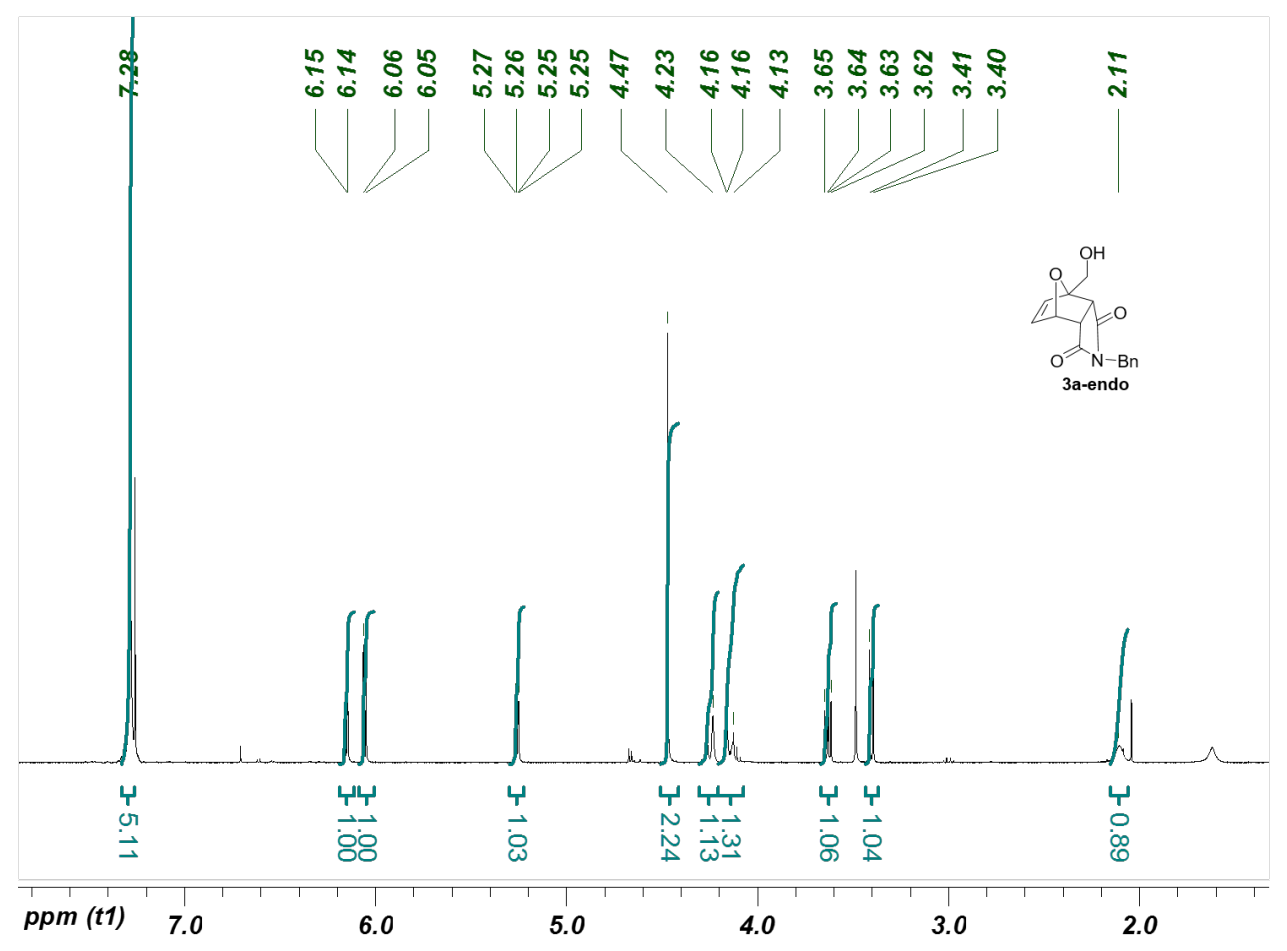

Figure S1. ${ }^{1} \mathrm{H}$ NMR spectrum of Compound 3a-endo $\left(\mathrm{CDCl}_{3}, 600 \mathrm{~Hz}\right)$.
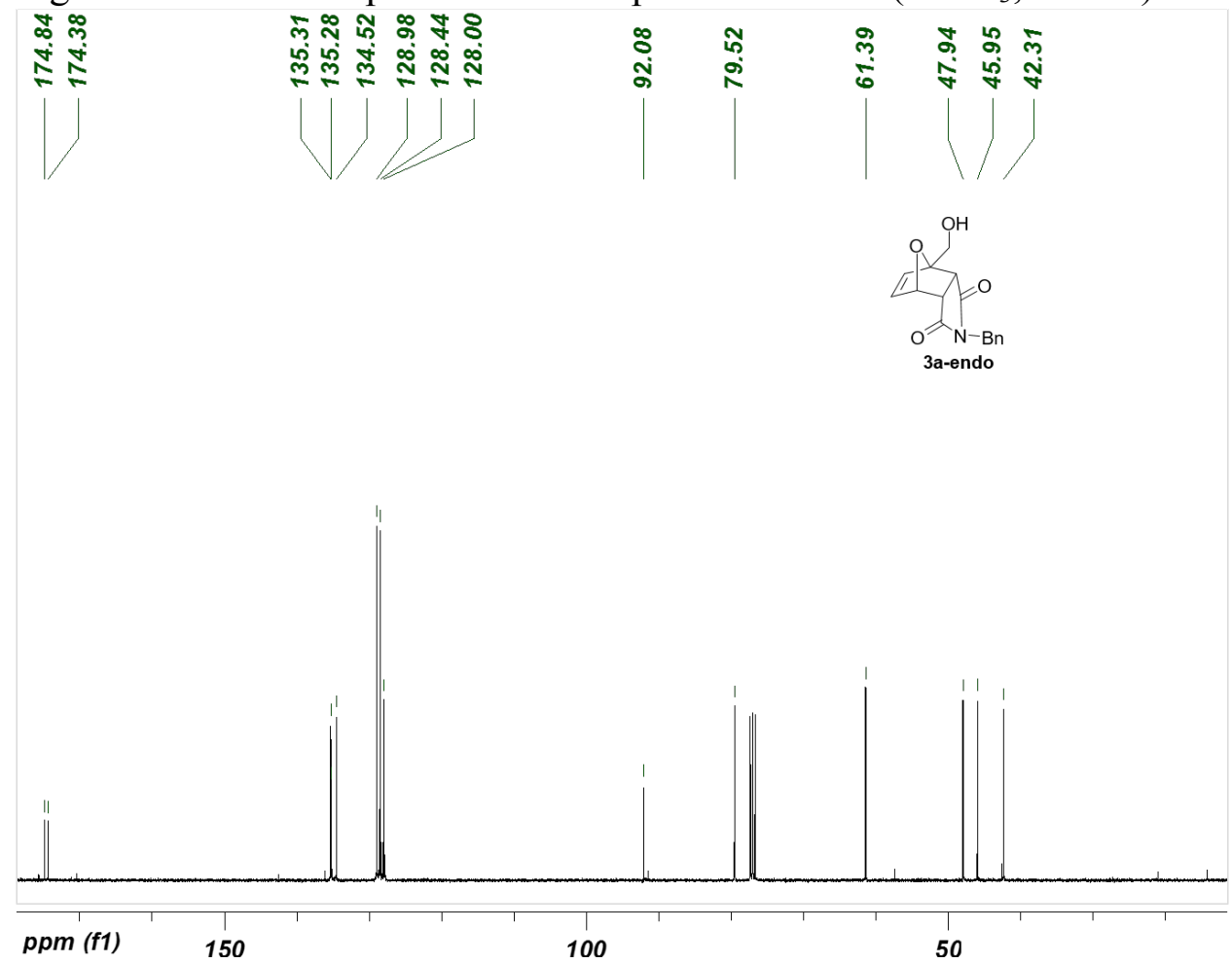

Figure S2. ${ }^{13} \mathrm{C}$ NMR spectrum of Compound 3a-endo $\left(\mathrm{CDCl}_{3}, 100 \mathrm{~Hz}\right)$. 


\section{ChemComm}

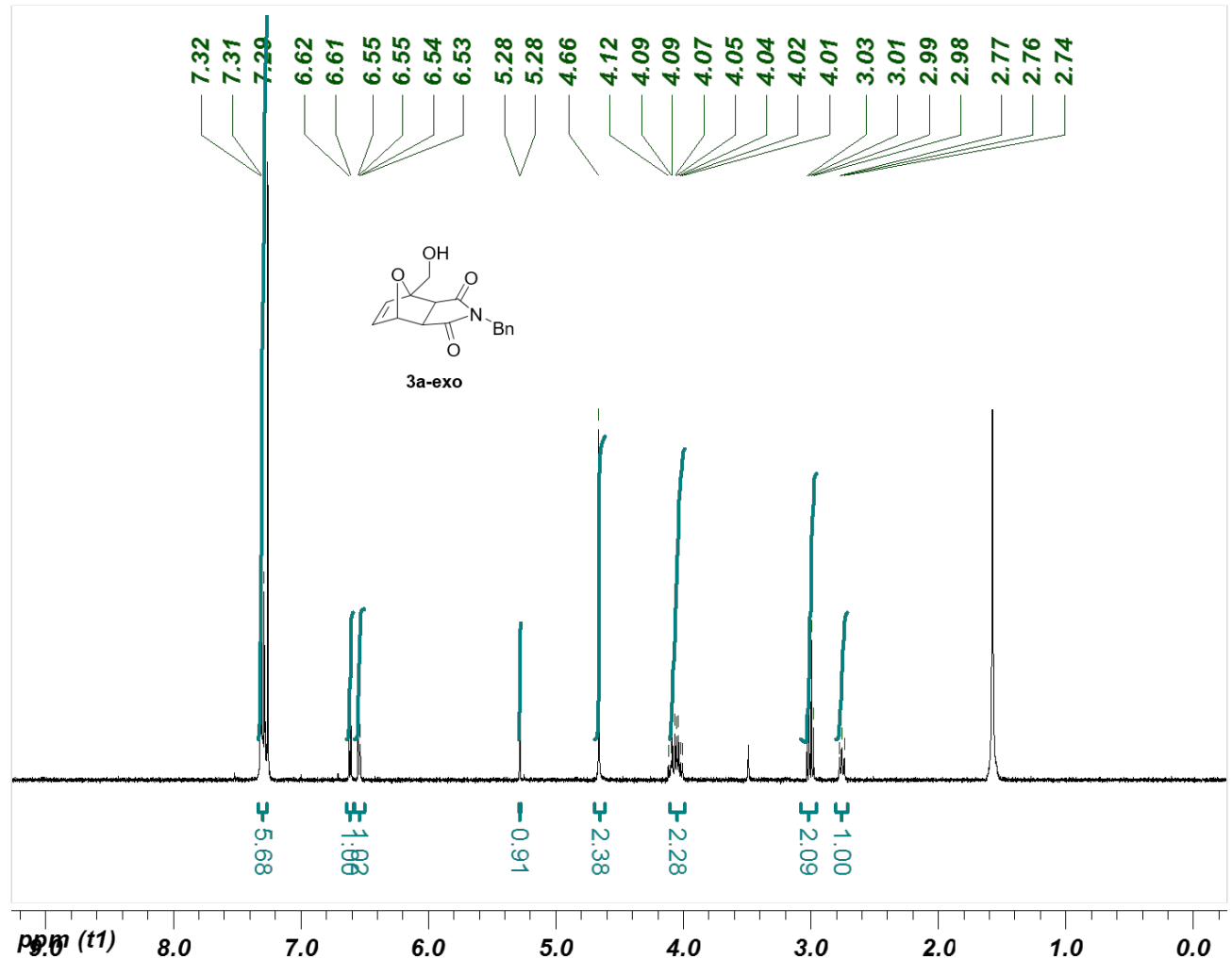

Figure S3. ${ }^{1} \mathrm{H}$ NMR spectrum of Compound 3a-exo $\left(\mathrm{CDCl}_{3}, 600 \mathrm{~Hz}\right)$
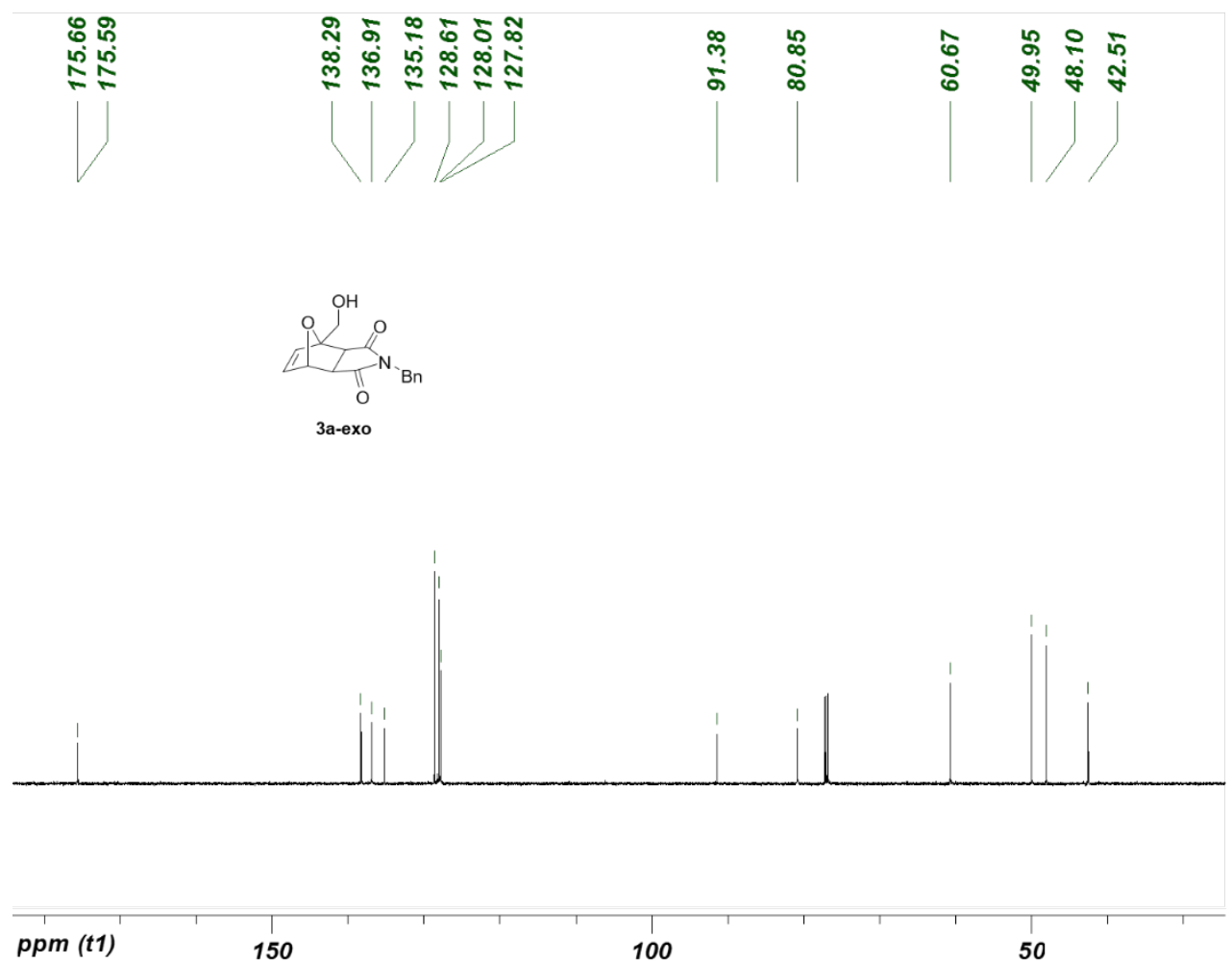

Figure S4. ${ }^{13} \mathrm{C}$ NMR spectrum of Compound 3a-exo $\left(\mathrm{CDCl}_{3}, 100 \mathrm{~Hz}\right)$. 


\section{ChemComm}

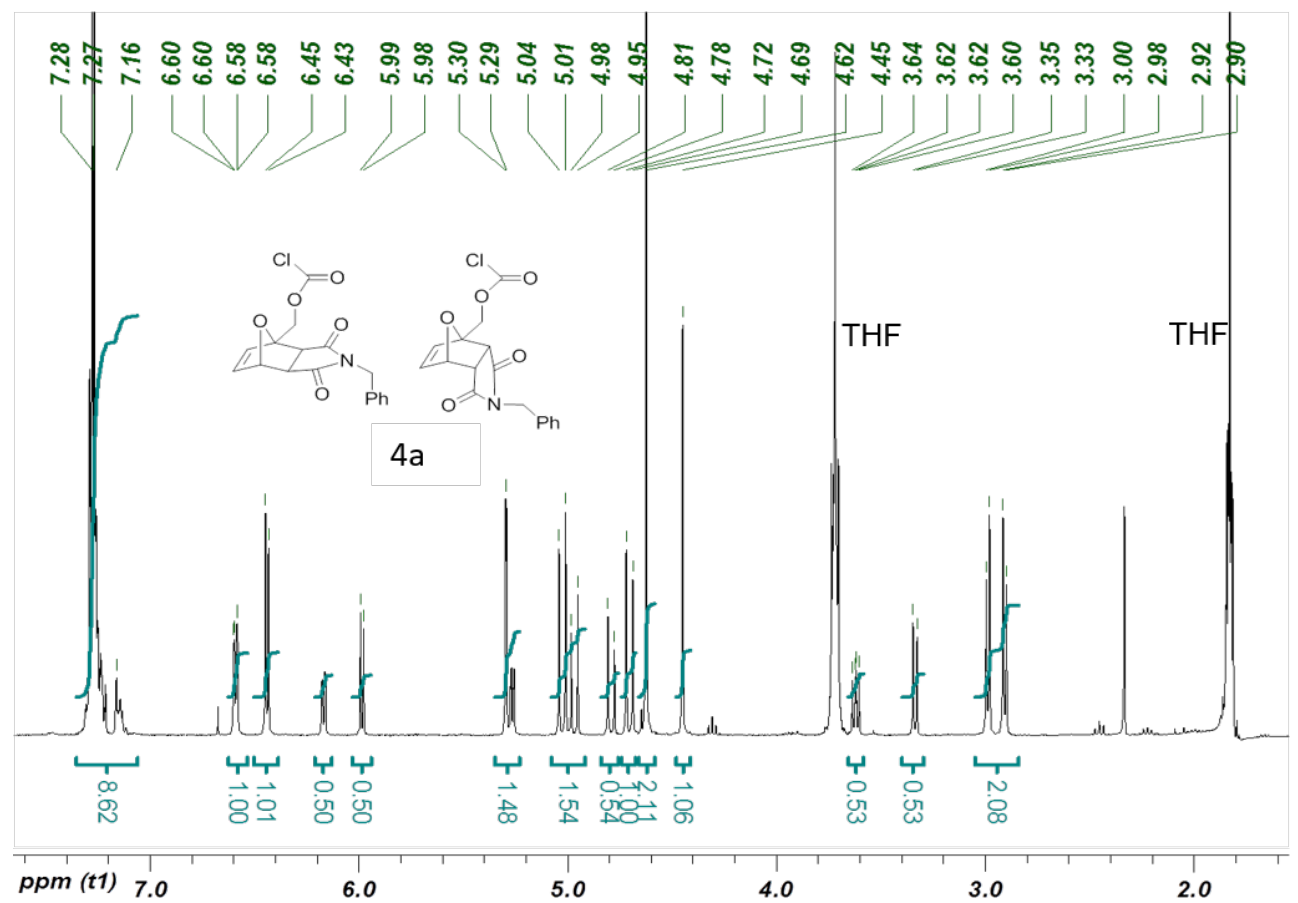

Figure S5. ${ }^{1} \mathrm{H} \mathrm{NMR}$ spectrum of Chloroformate $4 \mathbf{a}\left(\mathrm{CDCl}_{3}, 400 \mathrm{~Hz}\right)$ (residual THF present).

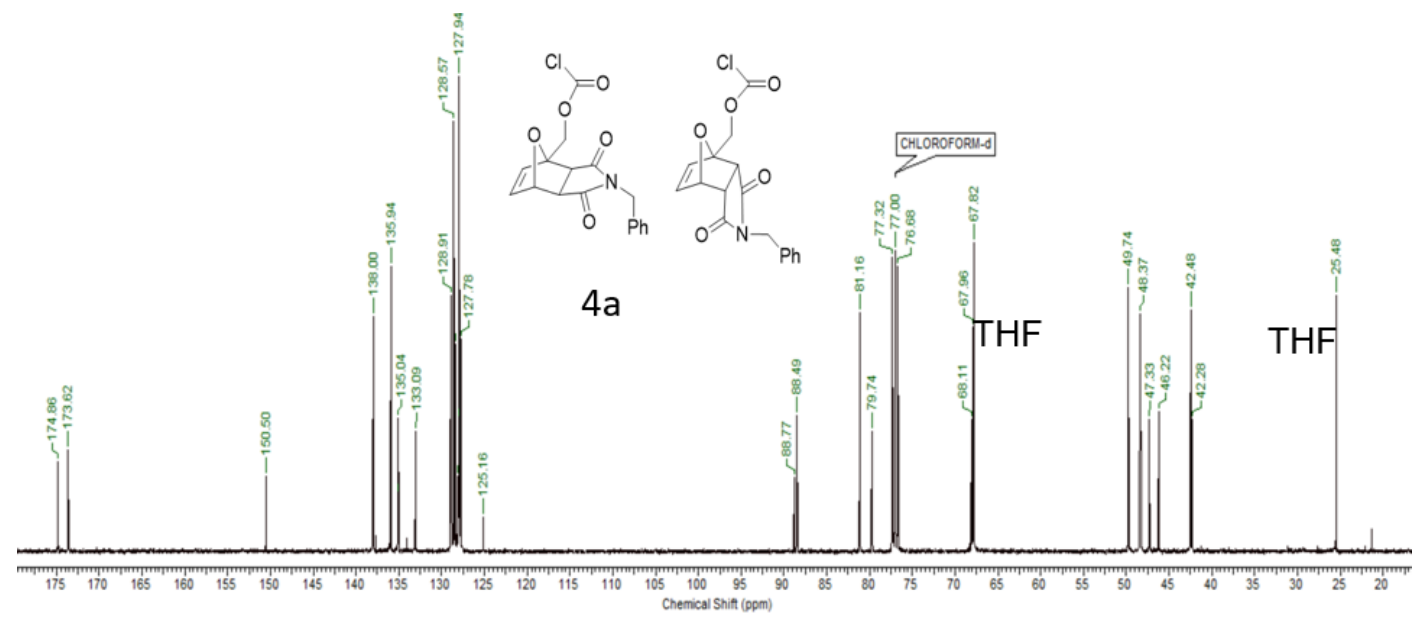

Figure S6. ${ }^{13} \mathrm{C}$ NMR spectrum of Chloroformate $\mathbf{4 a}\left(\mathrm{CDCl}_{3}, 100 \mathrm{~Hz}\right)$. 


\section{ChemComm}

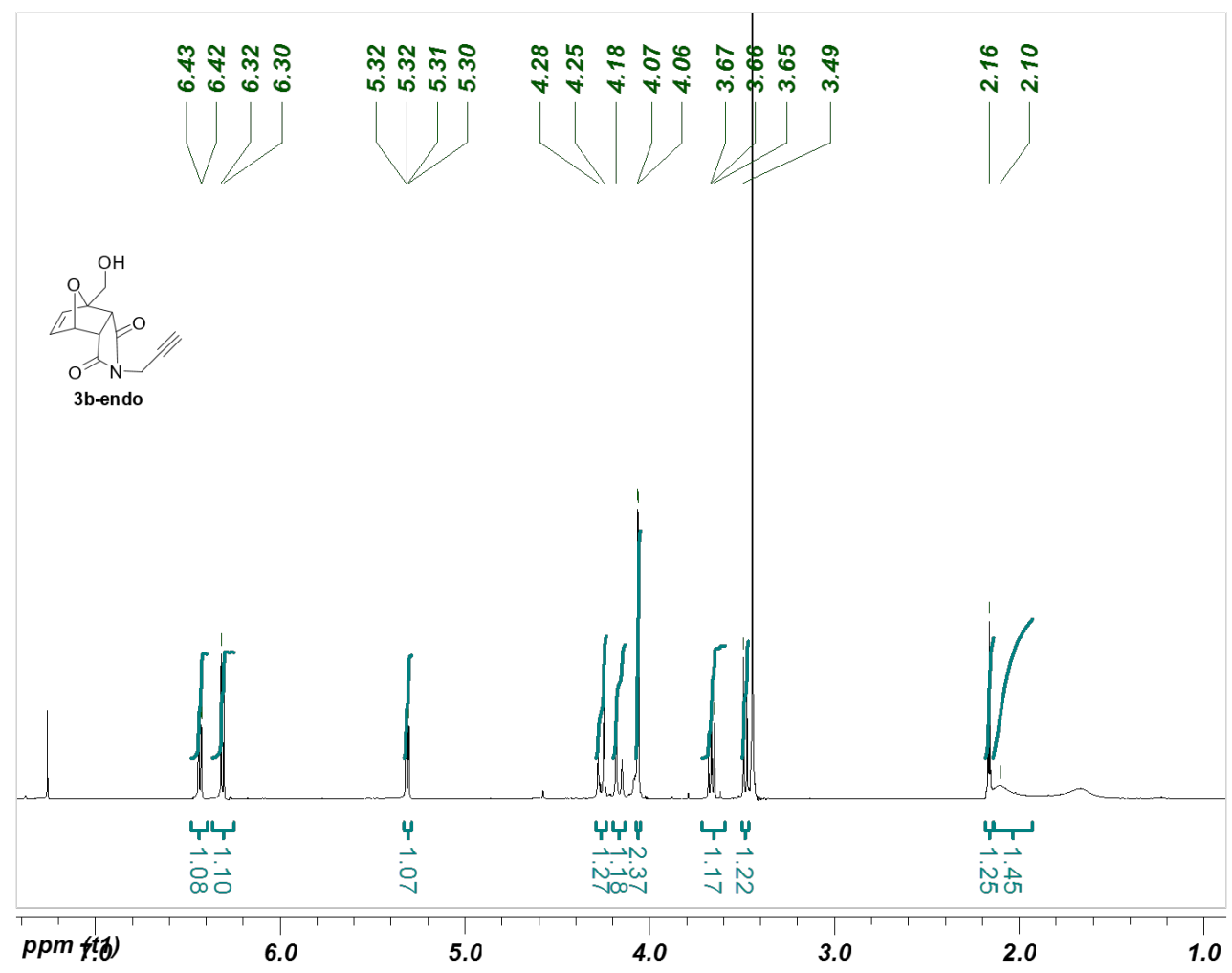

Figure S7. ${ }^{1} \mathrm{H}$ NMR spectrum of Compound 3b-endo $\left(\mathrm{CDCl}_{3}, 600 \mathrm{~Hz}\right)$.
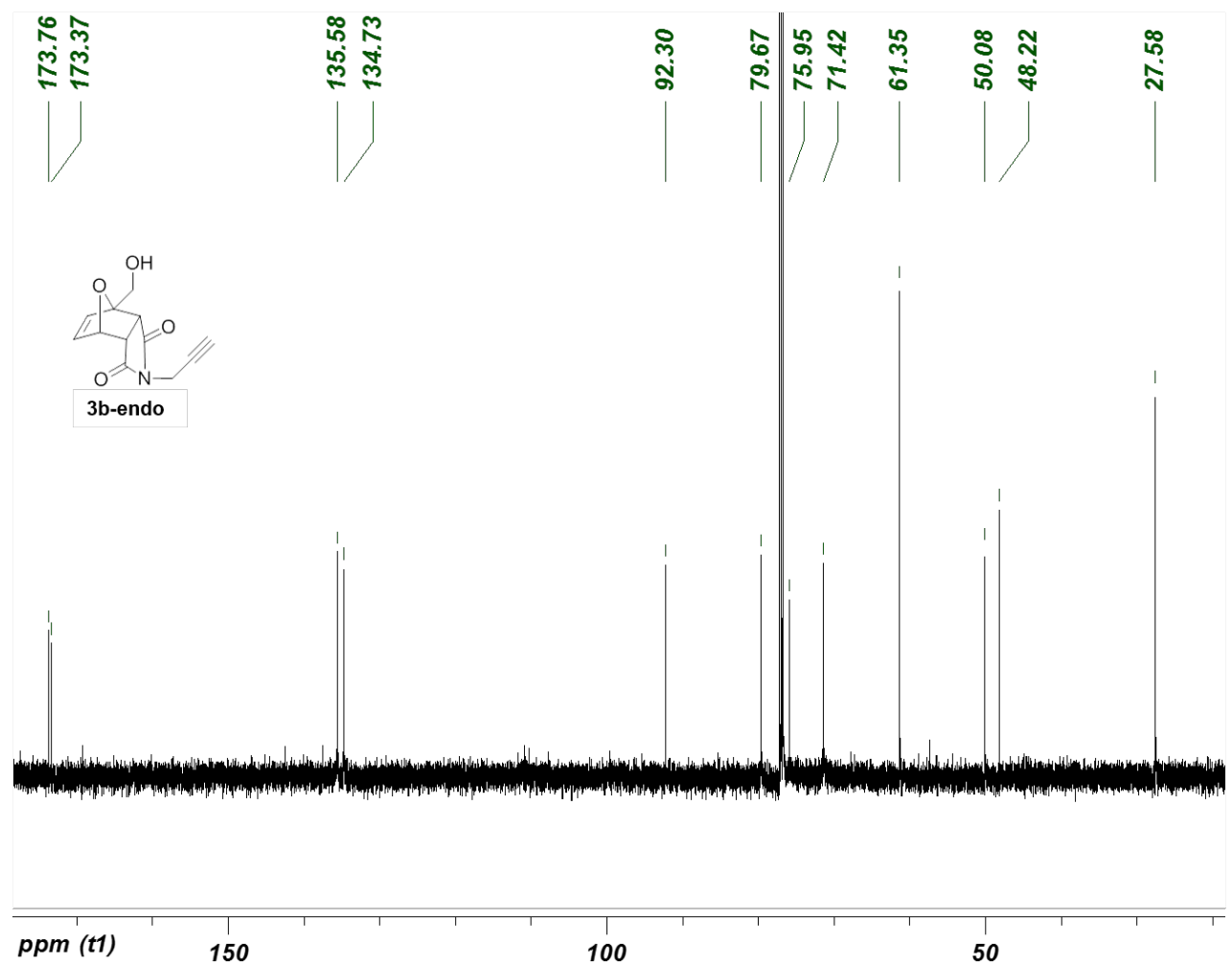

Figure S8. ${ }^{13} \mathrm{C}$ NMR spectrum of Compound 3b-endo $\left(\mathrm{CDCl}_{3}, 100 \mathrm{~Hz}\right)$. 


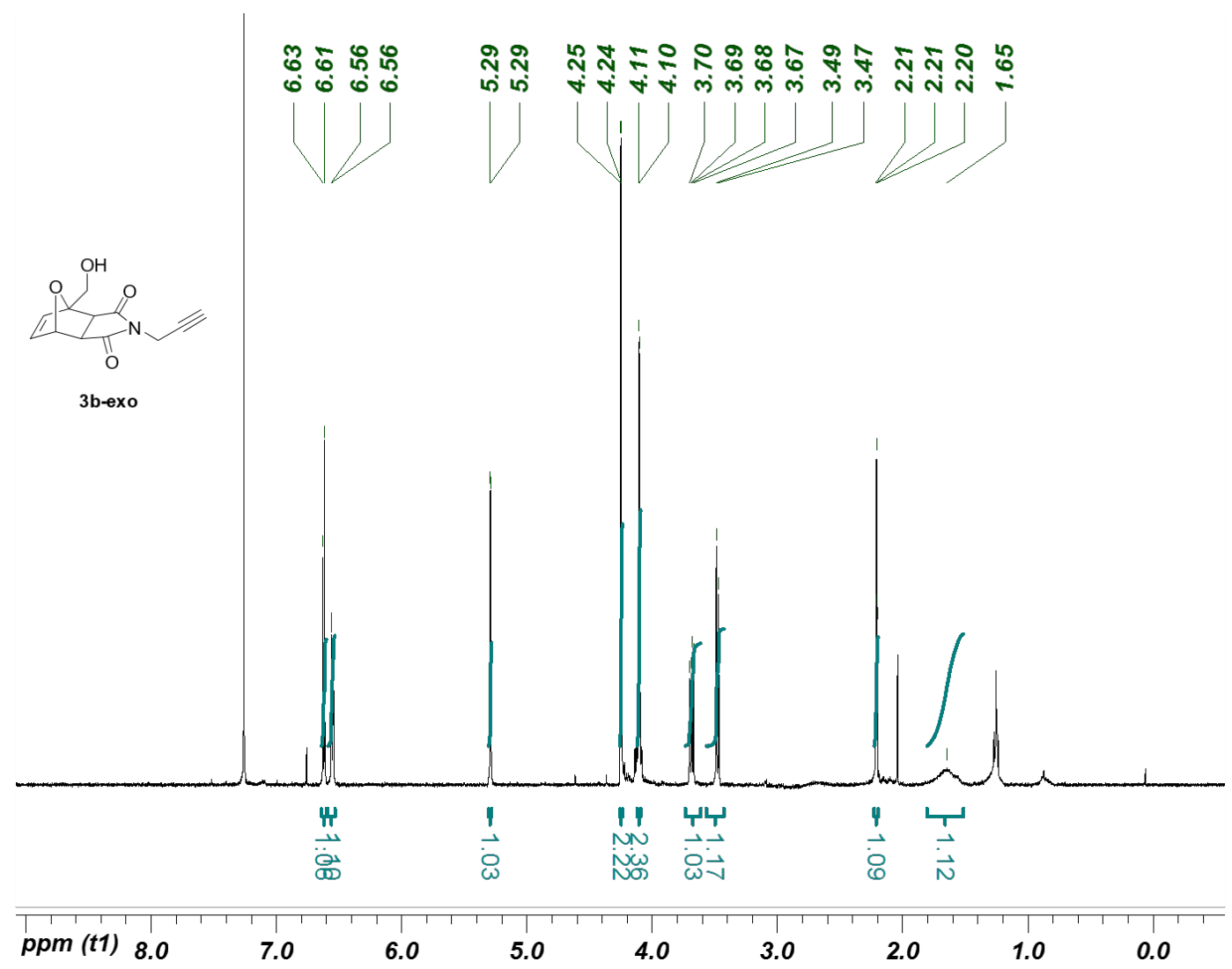

Figure S9. ${ }^{1} \mathrm{H}$ NMR spectrum of Compound $\mathbf{3 b}$-exo $\left(\mathrm{CDCl}_{3}, 400 \mathrm{~Hz}\right)$.
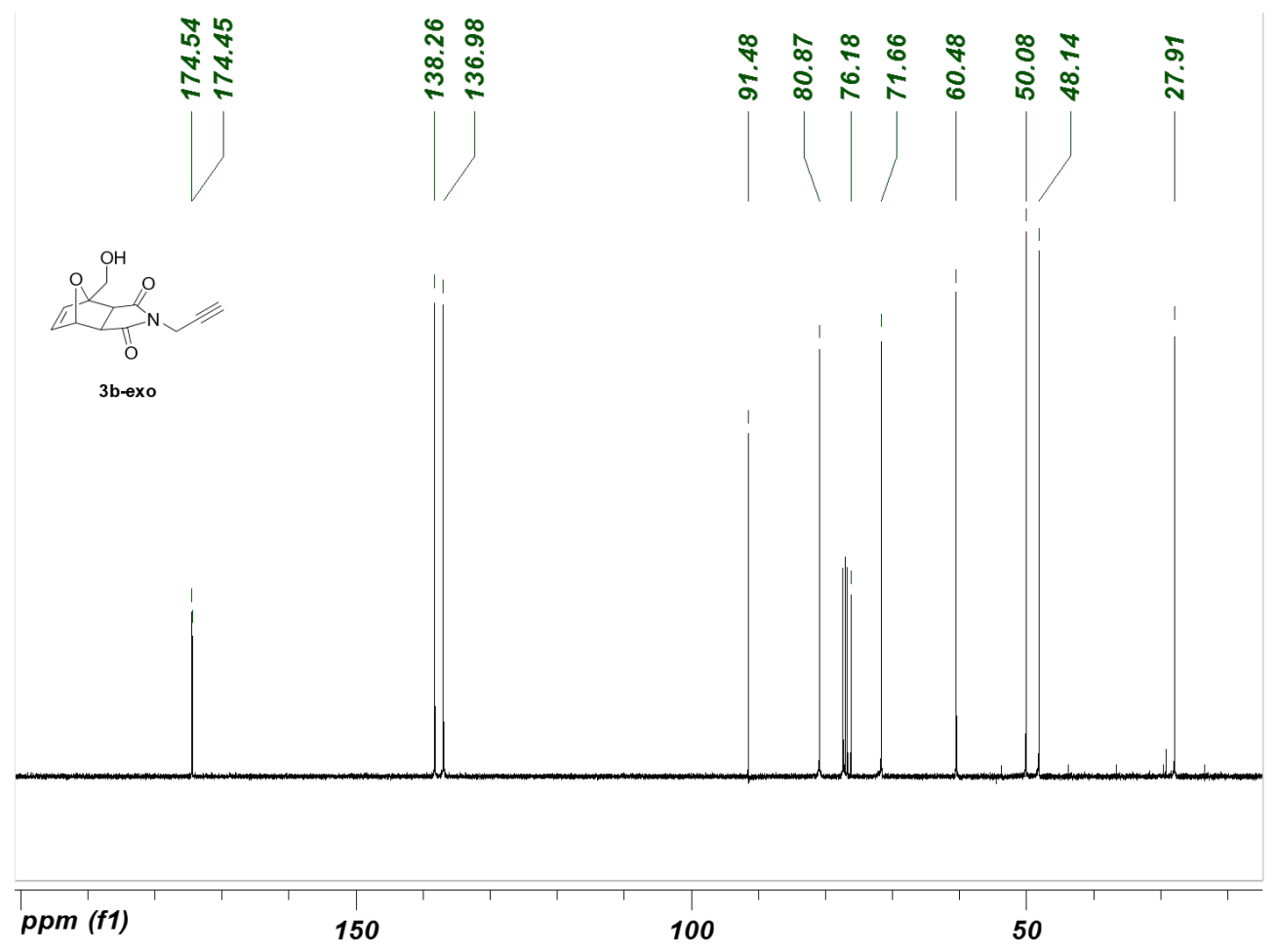

Figure S10. ${ }^{13} \mathrm{C}$ NMR spectrum of Compound $\mathbf{3 b}$-exo $\left(\mathrm{CDCl}_{3}, 100 \mathrm{~Hz}\right)$. 


\section{ChemComm}

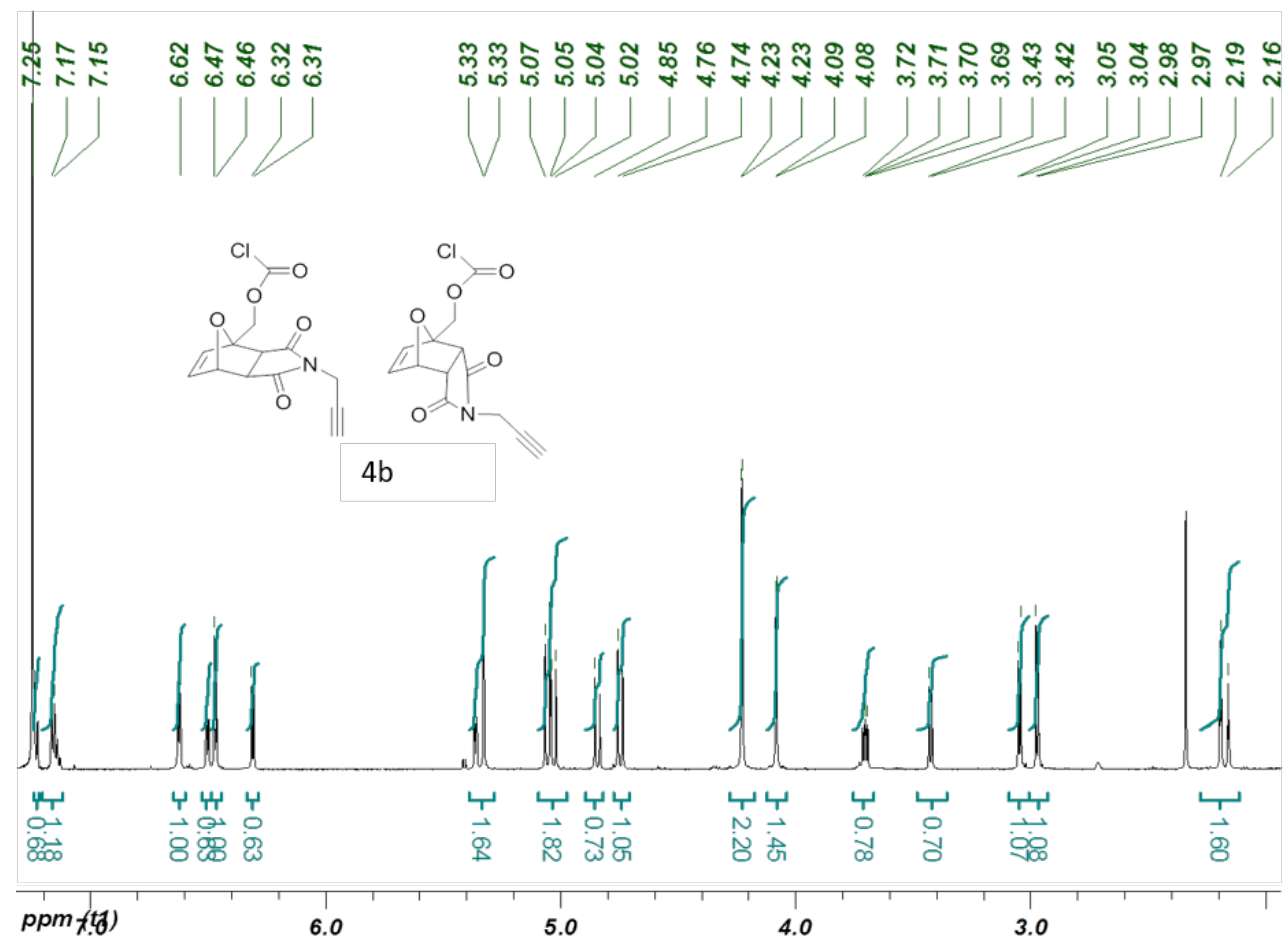

Figure S11. ${ }^{1} \mathrm{H}$ NMR spectrum of Chloroformate $\mathbf{4 b}\left(\mathrm{CDCl}_{3}, 400 \mathrm{~Hz}\right)$.

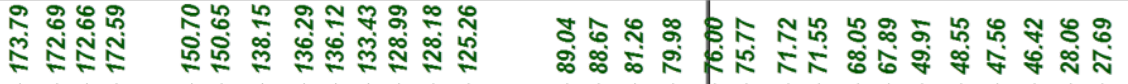
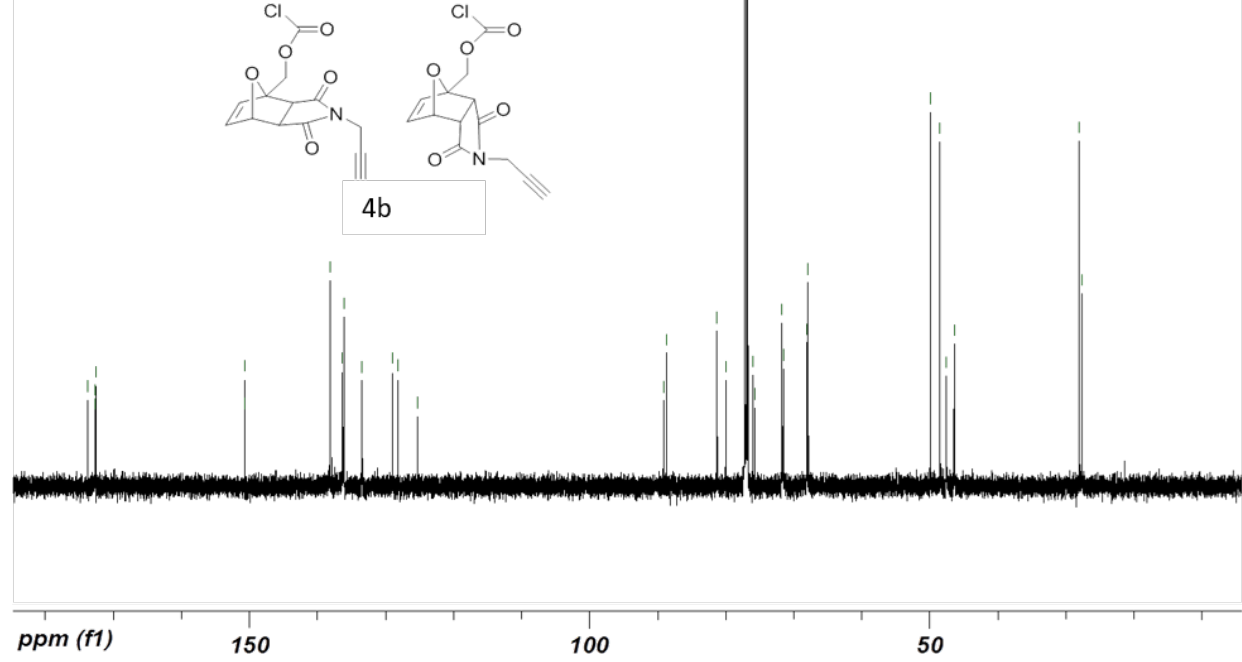

Figure S12. ${ }^{13} \mathrm{C}$ NMR spectrum of Chloroformate $\mathbf{4 b}\left(\mathrm{CDCl}_{3}, 100 \mathrm{~Hz}\right)$. 


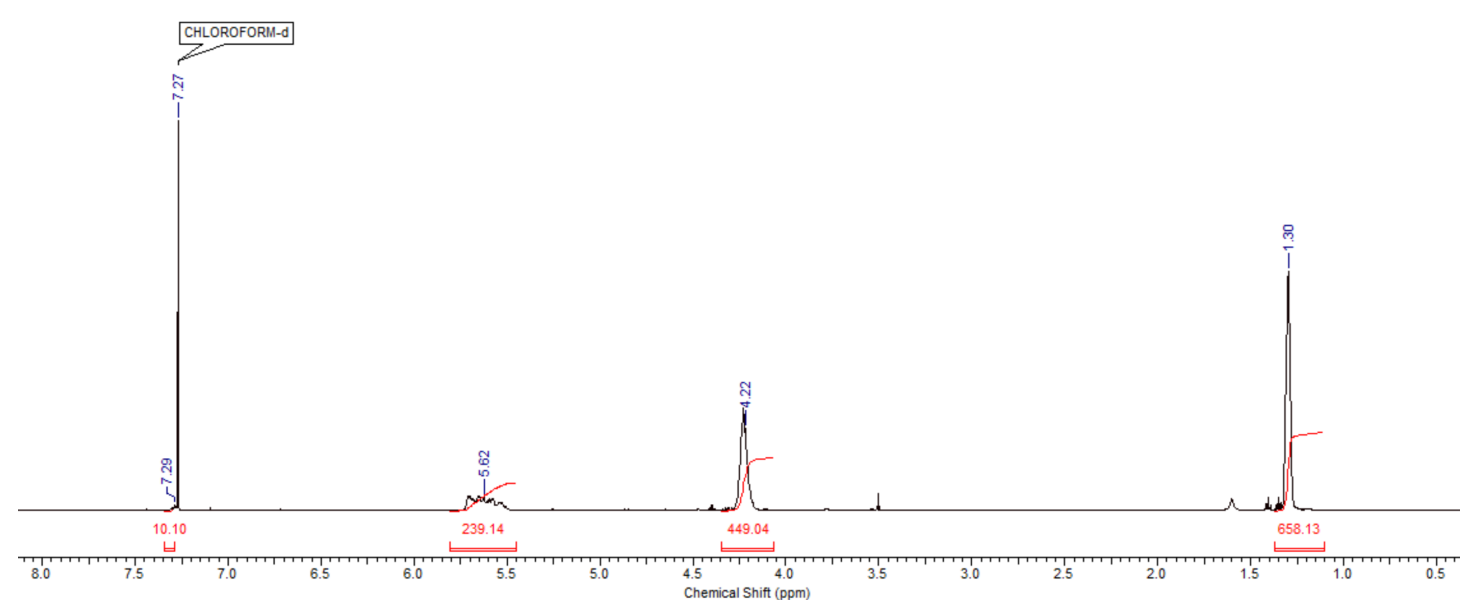

Figure S13. ${ }^{1} \mathrm{H}$ NMR spectrum of PEtG-DA-Bn $\left(\mathrm{CDCl}_{3}, 600 \mathrm{~Hz}\right)$.

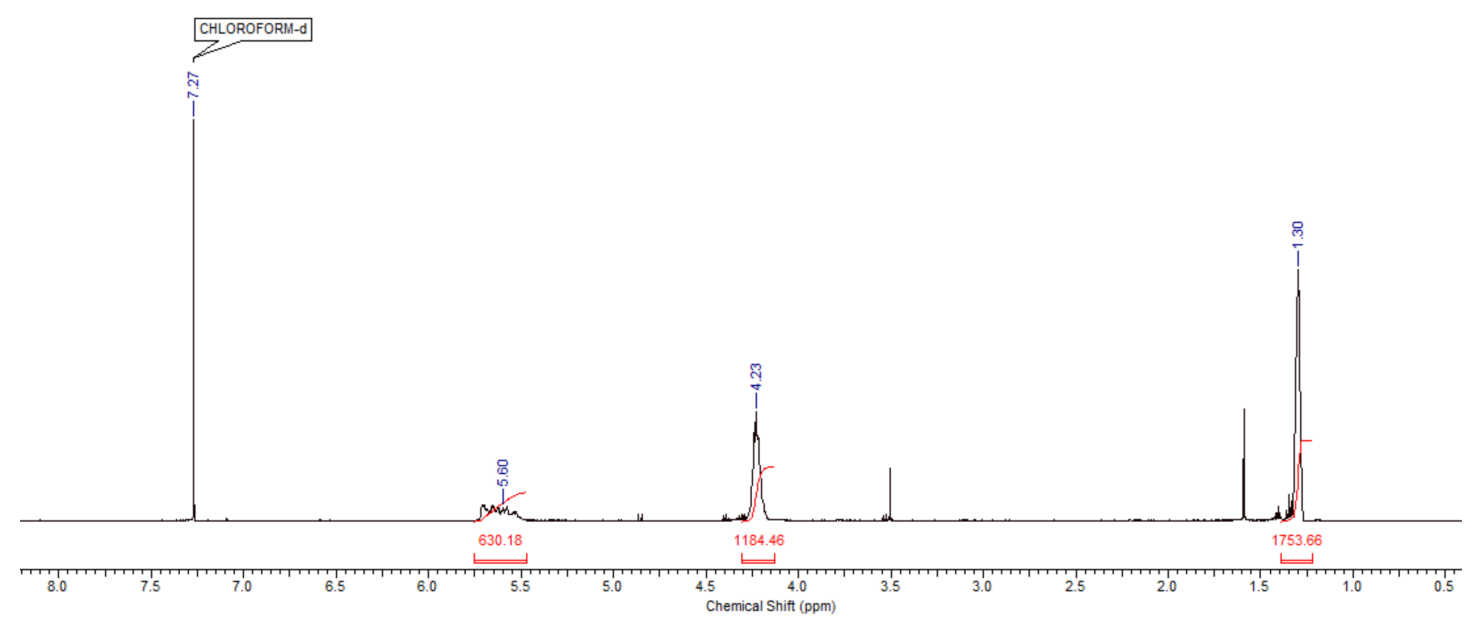

Figure S14. ${ }^{1} \mathrm{H}$ NMR spectrum of PEtG-DA-alkyne $\left(\mathrm{CDCl}_{3}, 600 \mathrm{~Hz}\right)$. 


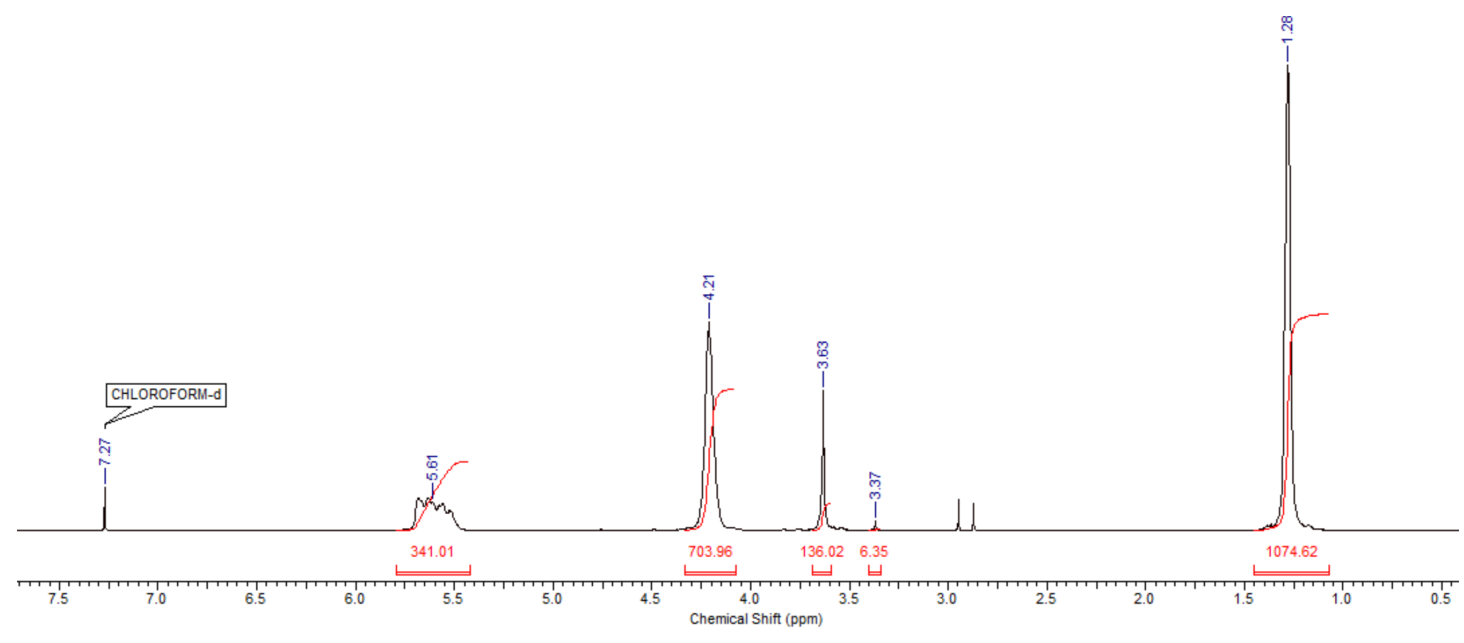

Figure S15. ${ }^{1} \mathrm{H}$ NMR spectrum of PEtG-DA-PEO750 $\left(\mathrm{CDCl}_{3}, 600 \mathrm{~Hz}\right)$. The success of the PEG coupling is evidenced by the presence of the PEG peak at $3.6 \mathrm{ppm}$ and its corresponding integration.

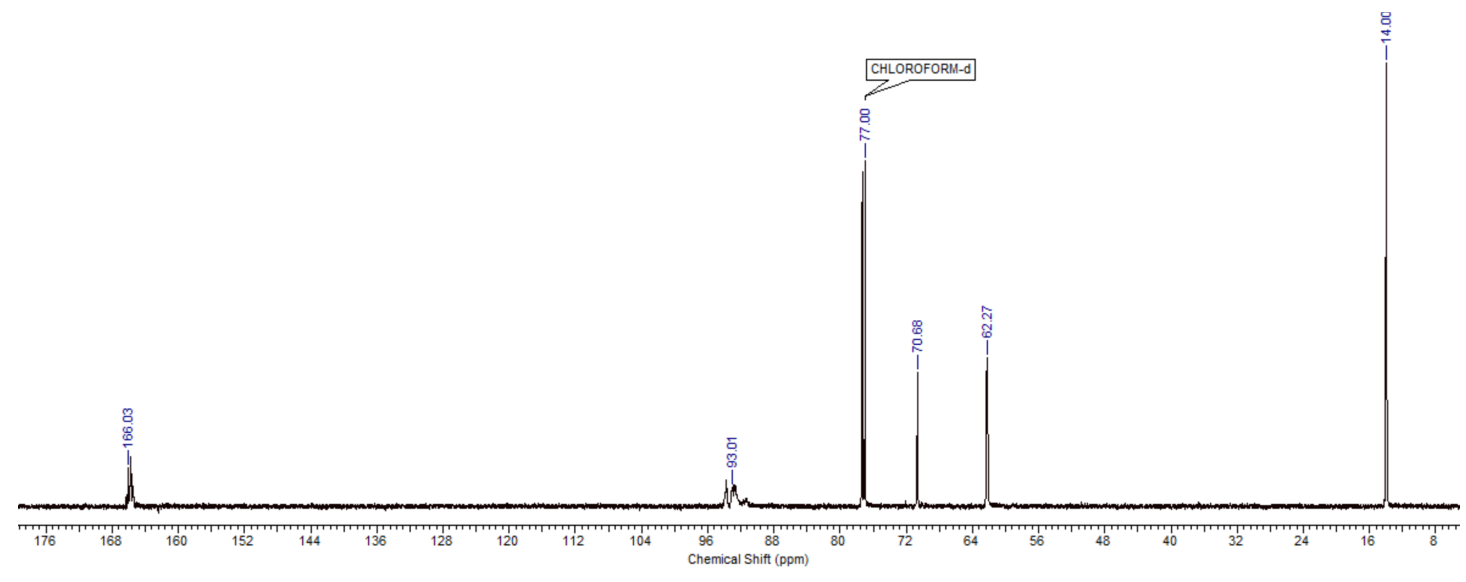

Figure S16. ${ }^{13} \mathrm{C}$ NMR spectrum of PEtG-DA-PEO750 $\left(\mathrm{CDCl}_{3}, 150 \mathrm{~Hz}\right)$. The success of the PEG coupling is evidenced by the presence of the PEG peak at $70 \mathrm{ppm}$. 


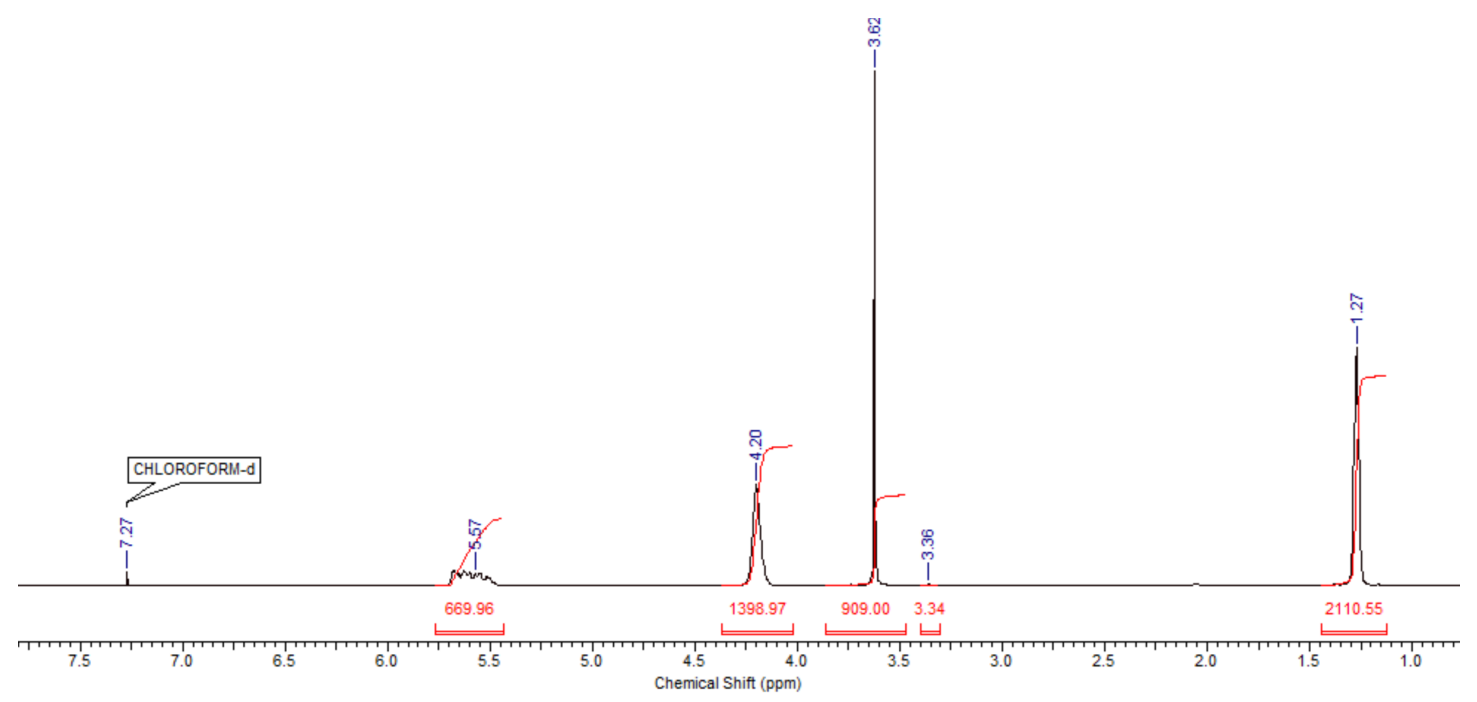

Figure S17. ${ }^{1} \mathrm{H}$ NMR spectrum of PEtG-DA-PEO5000 $\left(\mathrm{CDCl}_{3}, 600 \mathrm{~Hz}\right)$. The success of the PEG coupling is evidenced by the presence of the PEG peak at $3.6 \mathrm{ppm}$ and its corresponding integration.

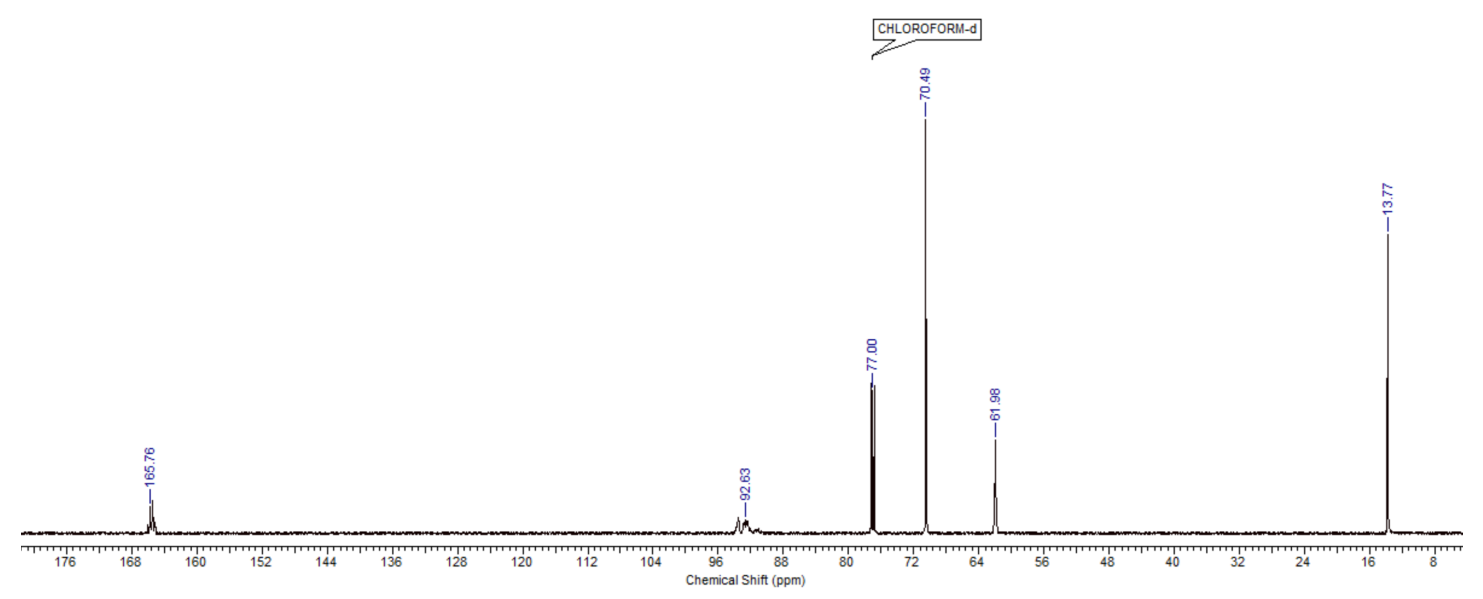

Figure S18. ${ }^{13} \mathrm{C}$ NMR spectrum of PEtG-DA-PEO5000 $\left(\mathrm{CDCl}_{3}, 150 \mathrm{~Hz}\right)$. The success of the PEG coupling is evidenced by the presence of the PEG peak at $70 \mathrm{ppm}$. 


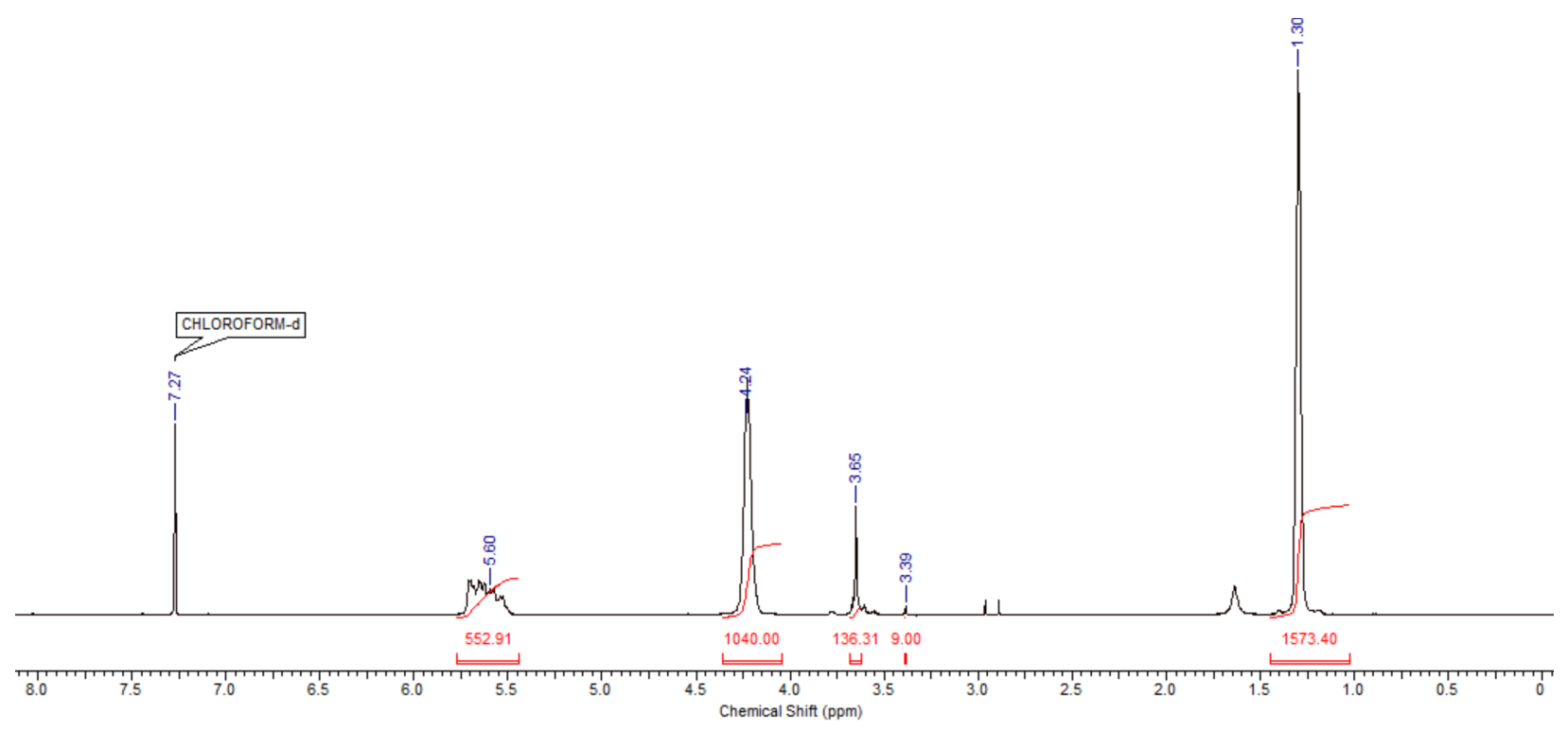

Figure S19. ${ }^{1} \mathrm{H}$ NMR spectrum of Vesicle-control $\left(\mathrm{CDCl}_{3}, 600 \mathrm{~Hz}\right)$. The success of the PEG coupling is evidenced by the presence of the PEG peak at $3.6 \mathrm{ppm}$ and its corresponding integration.

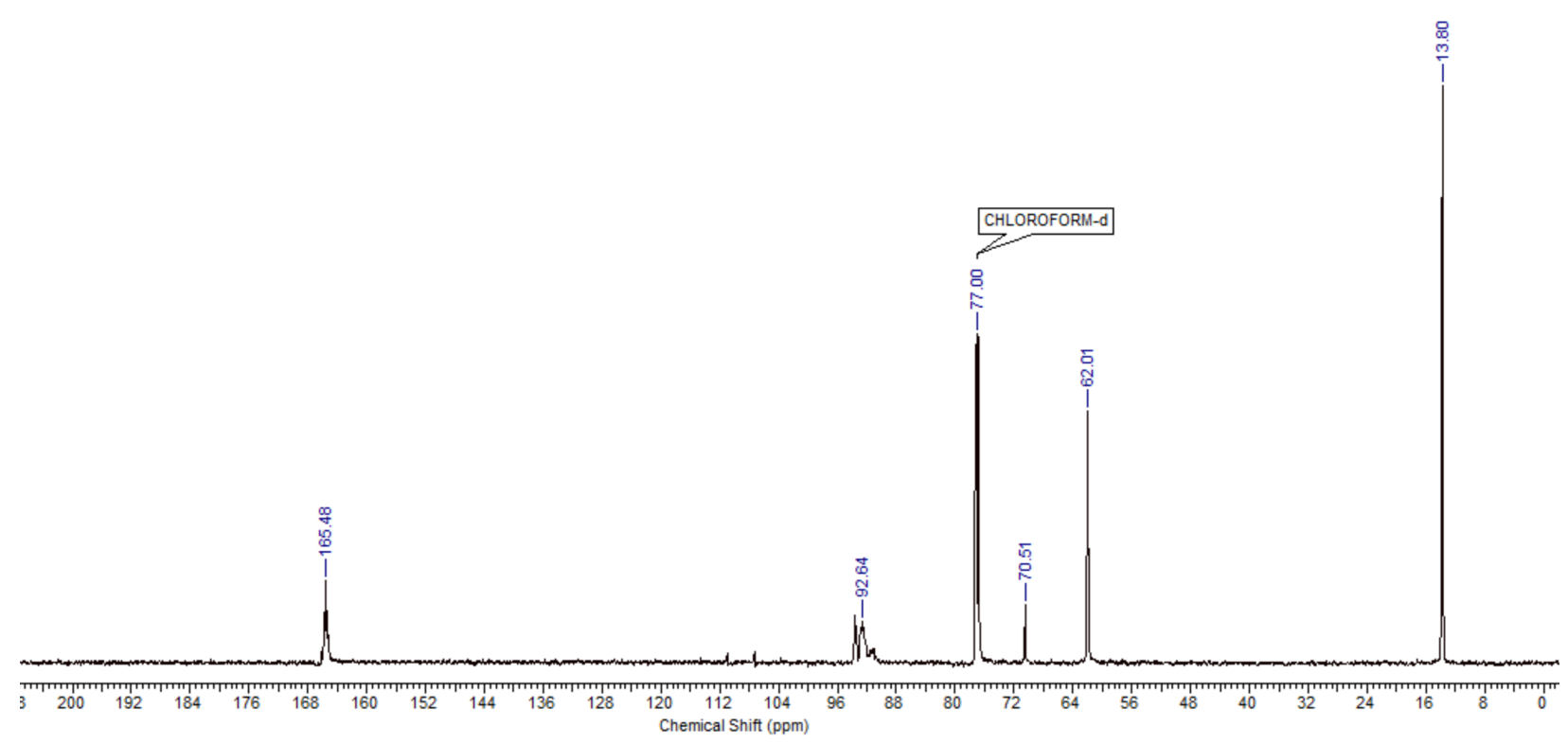

Figure S20. ${ }^{13} \mathrm{C}$ NMR spectrum of Vesicle-control $\left(\mathrm{CDCl}_{3}, 150 \mathrm{~Hz}\right)$. The success of the PEG coupling is evidenced by the presence of the PEG peak at $70 \mathrm{ppm}$. 


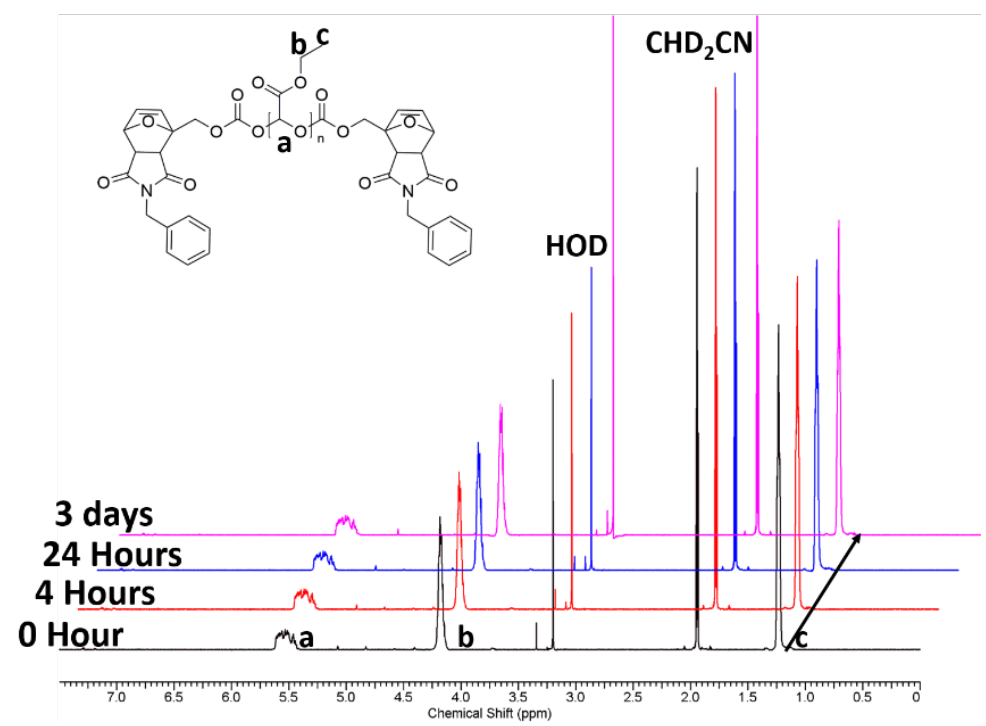

Figure S21. ${ }^{1} \mathrm{H}$ NMR spectra of PEtG-DA-Bn incubated in 9:1 $\mathrm{CD}_{3} \mathrm{CN}: \mathrm{D}_{2} \mathrm{O}$ at $22{ }^{\circ} \mathrm{C}$ over time. Spectra are offset to allow the progression over time to be clearly observed.
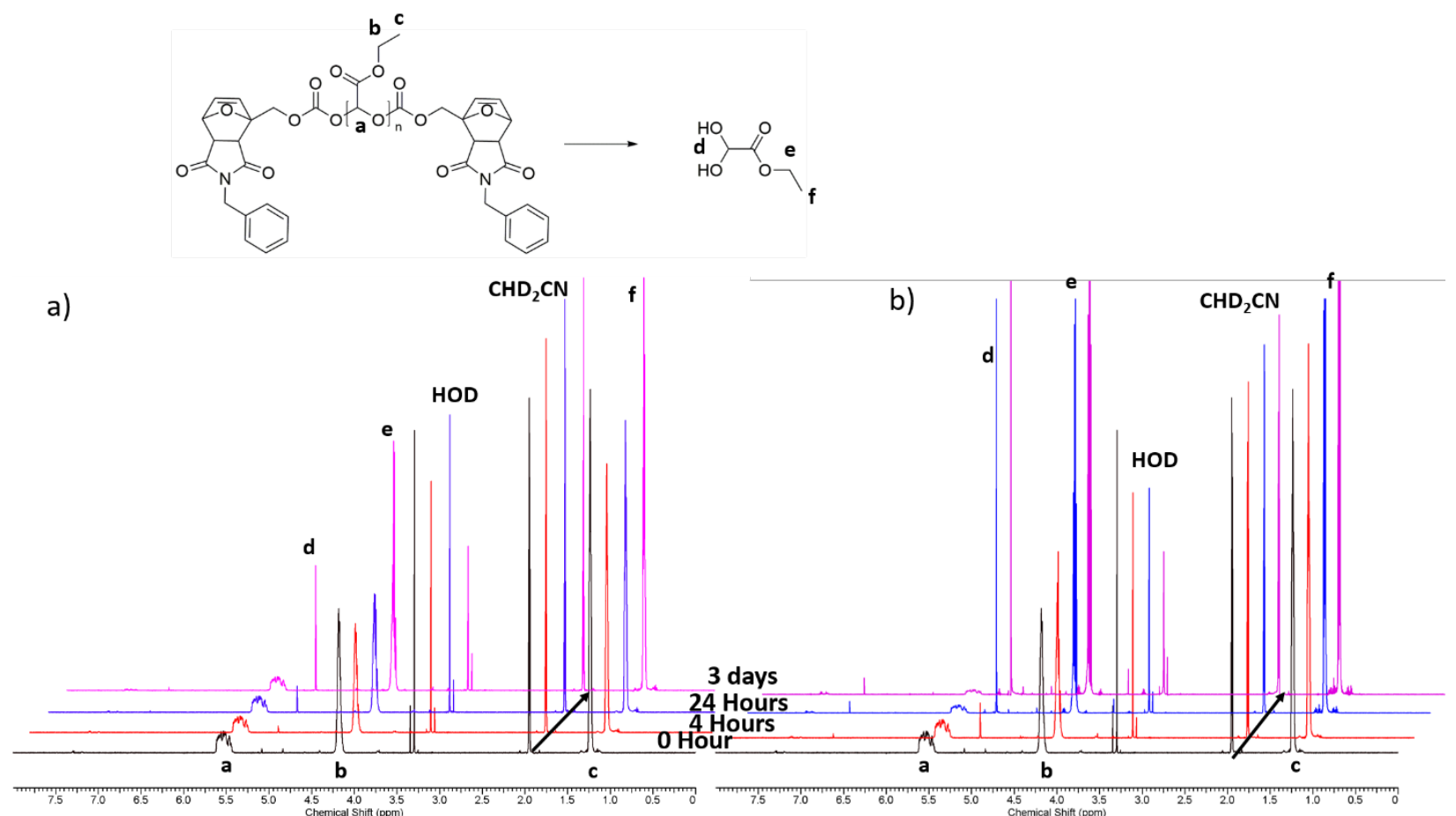

Figure S22. ${ }^{1} \mathrm{H}$ NMR spectra of PEtG-DA-Bn incubated in 9:1 $\mathrm{CD}_{3} \mathrm{CN}: \mathrm{D}_{2} \mathrm{O}$ at a) $40{ }^{\circ} \mathrm{C}$ and b) $60{ }^{\circ} \mathrm{C}$. Spectra are offset to allow the progression over time to be clearly observed. 


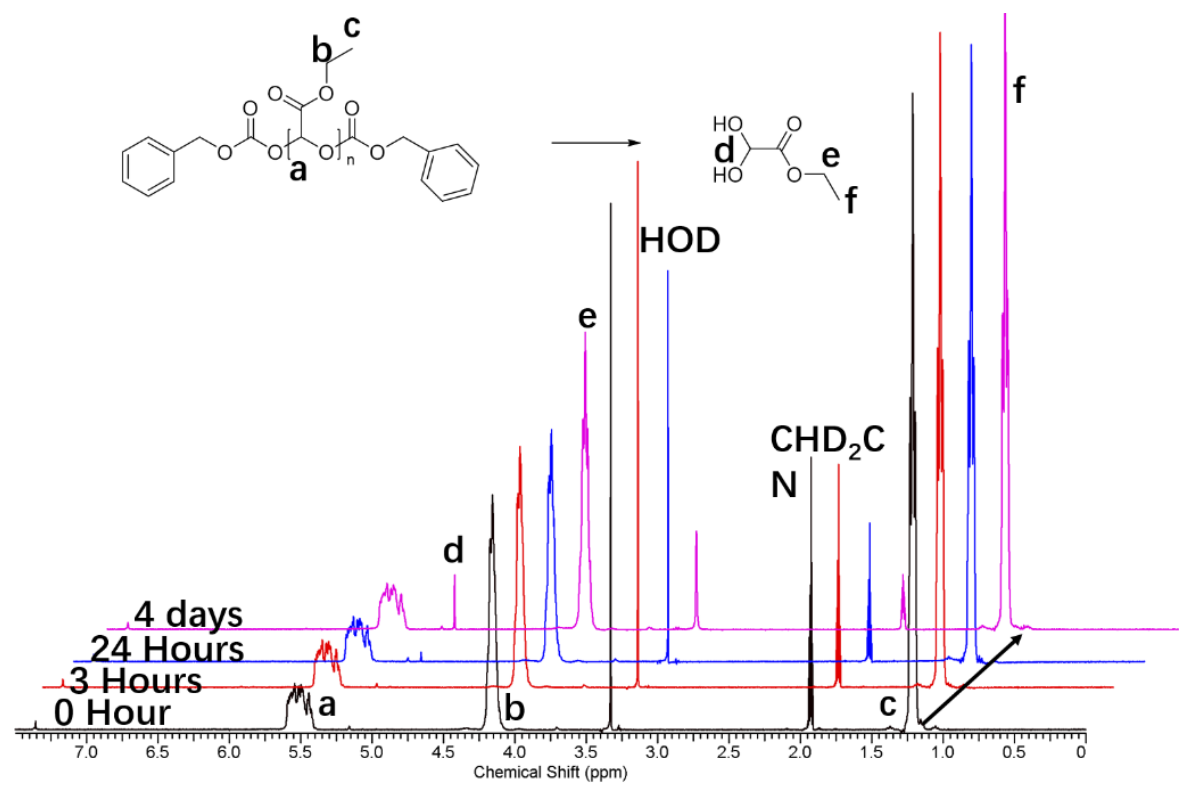

Figure S23. ${ }^{1} \mathrm{H}$ NMR spectra of PEtG-control incubated in 9:1 $\mathrm{CD}_{3} \mathrm{CN}: \mathrm{D}_{2} \mathrm{O}$ at $75{ }^{\circ} \mathrm{C}$. Spectra are offset to allow the progression over time to be clearly observed.

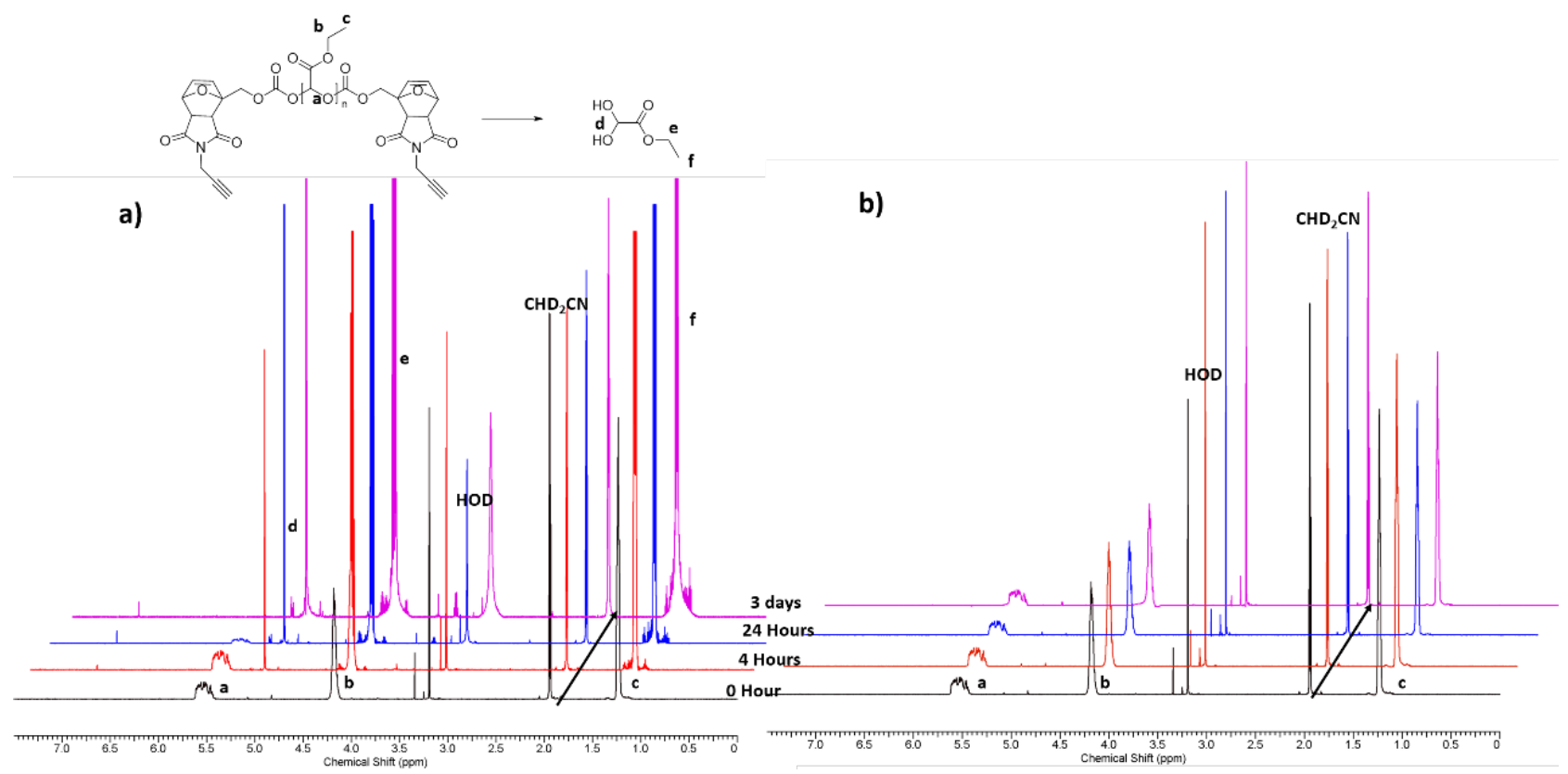

Figure S24. ${ }^{1} \mathrm{H}$ NMR spectra of PEtG-DA-alkyne incubated in 9:1 $\mathrm{CD}_{3} \mathrm{CN}: \mathrm{D}_{2} \mathrm{O}$ at a) $75{ }^{\circ} \mathrm{C}$ and b) $22{ }^{\circ} \mathrm{C}$. Spectra are offset to allow the progression over time to be clearly observed. 
a)
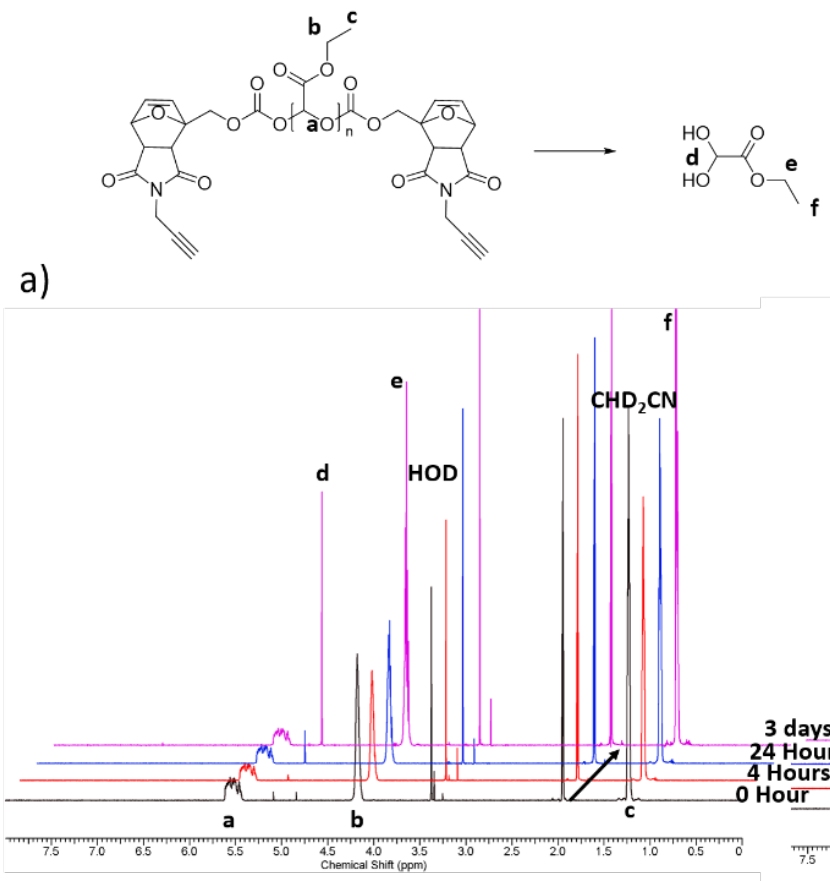

b)

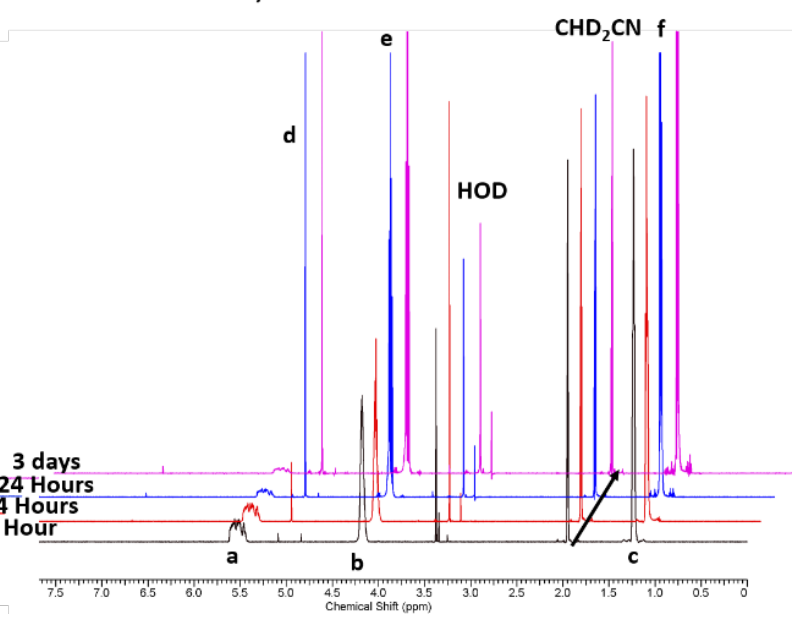

Figure S25. ${ }^{1} \mathrm{H}$ NMR spectra of PEtG-DA-alkyne incubated in 9:1 $\mathrm{CD}_{3} \mathrm{CN}: \mathrm{D}_{2} \mathrm{O}$ at a) $40{ }^{\circ} \mathrm{C}$ and b) $60{ }^{\circ} \mathrm{C}$. Spectra are offset to allow the progression over time to be clearly observed.

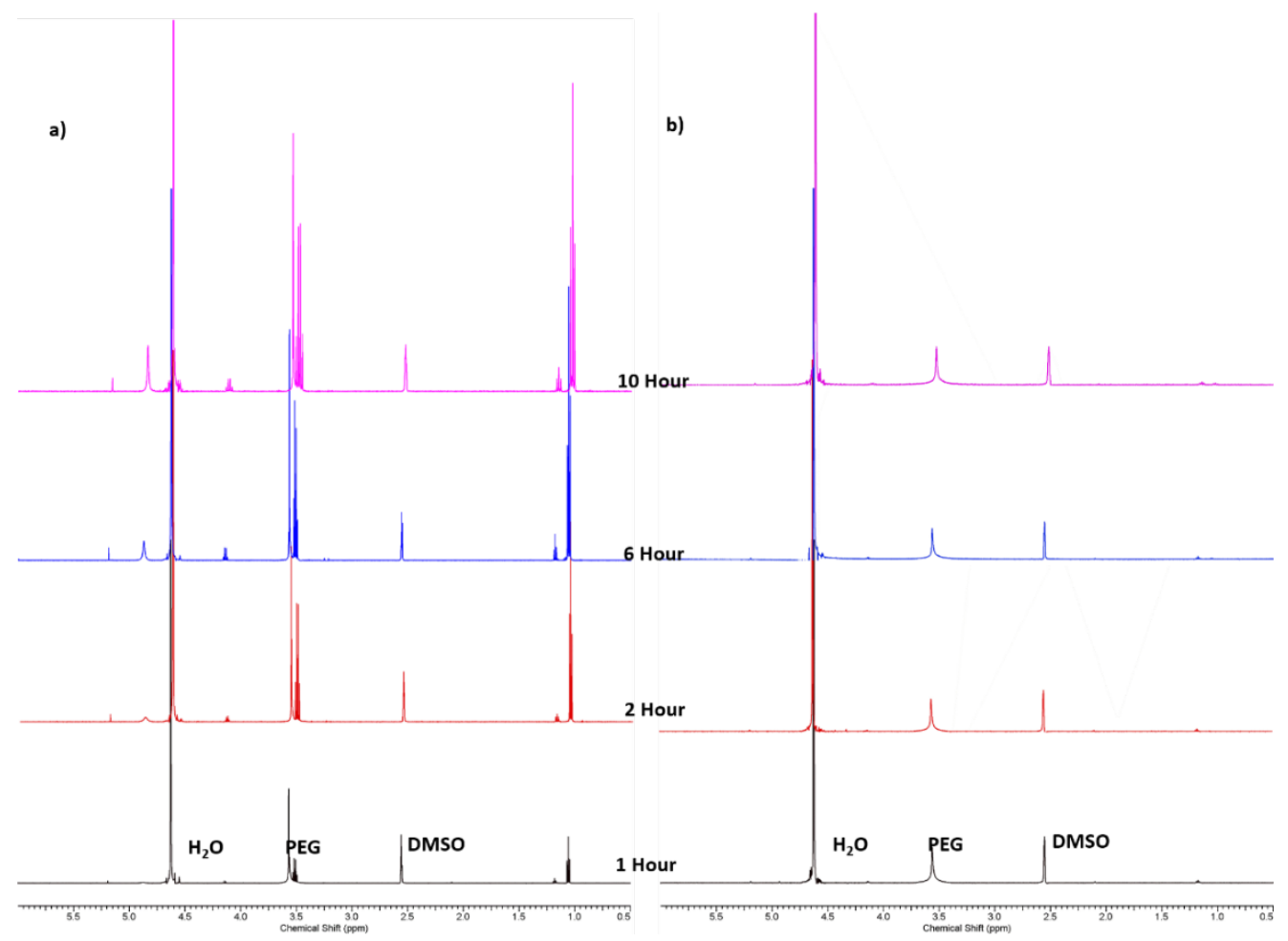

Figure S26. ${ }^{1} \mathrm{H}$ NMR spectra of PEtG-DA-PEO5000 micelles incubated in 5:1 DMSO- $d_{6}: \mathrm{D}_{2} \mathrm{O}$ at a) $75{ }^{\circ} \mathrm{C}$ and b) $22{ }^{\circ} \mathrm{C}$. 


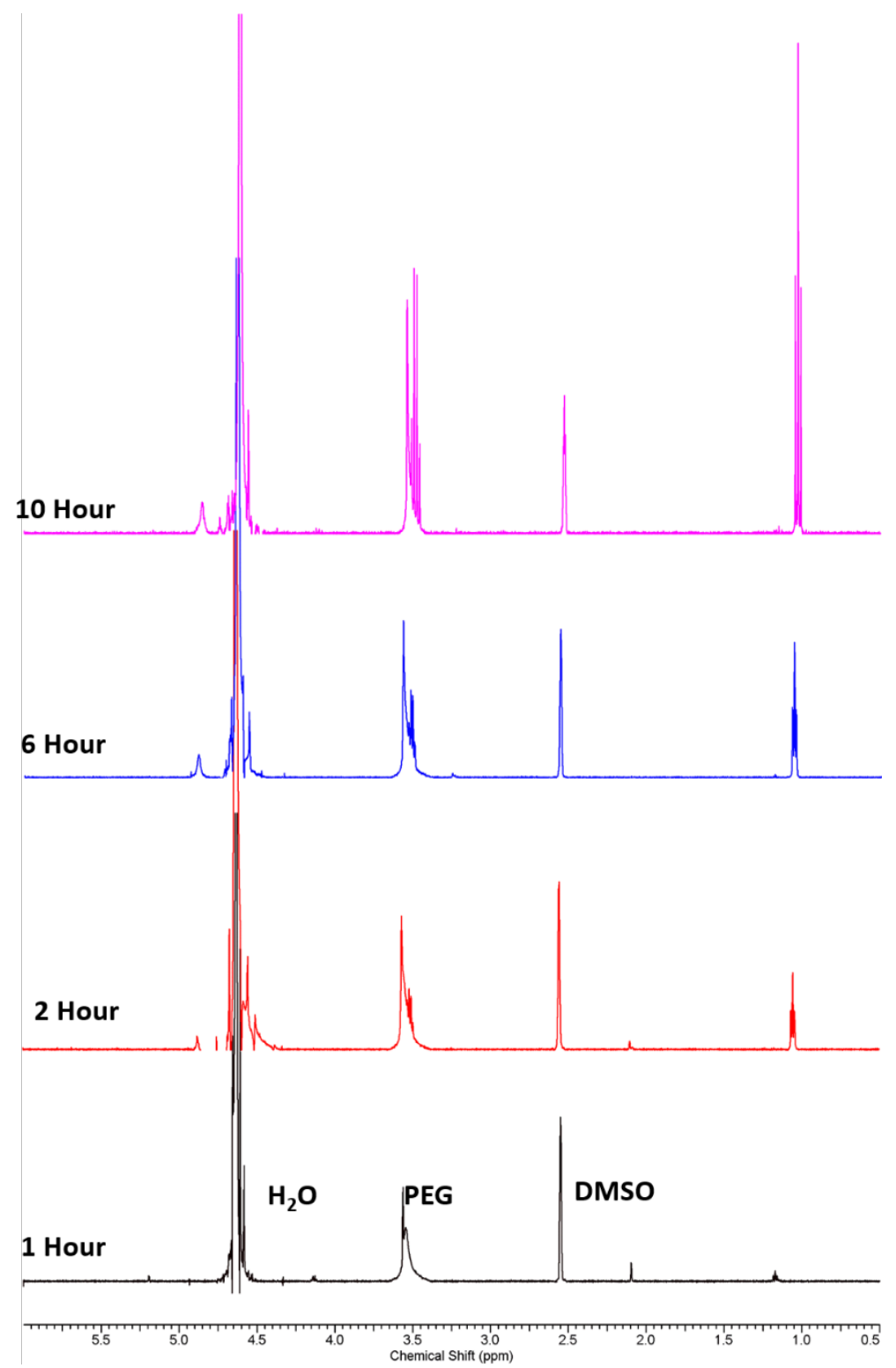

Figure S27. ${ }^{1} \mathrm{H}$ NMR spectra of Micelle-control incubated in 5:1 DMSO- $d_{6}: \mathrm{D}_{2} \mathrm{O}$ at $75{ }^{\circ} \mathrm{C}$. 


\section{TGA curves of end-caps and polymers}
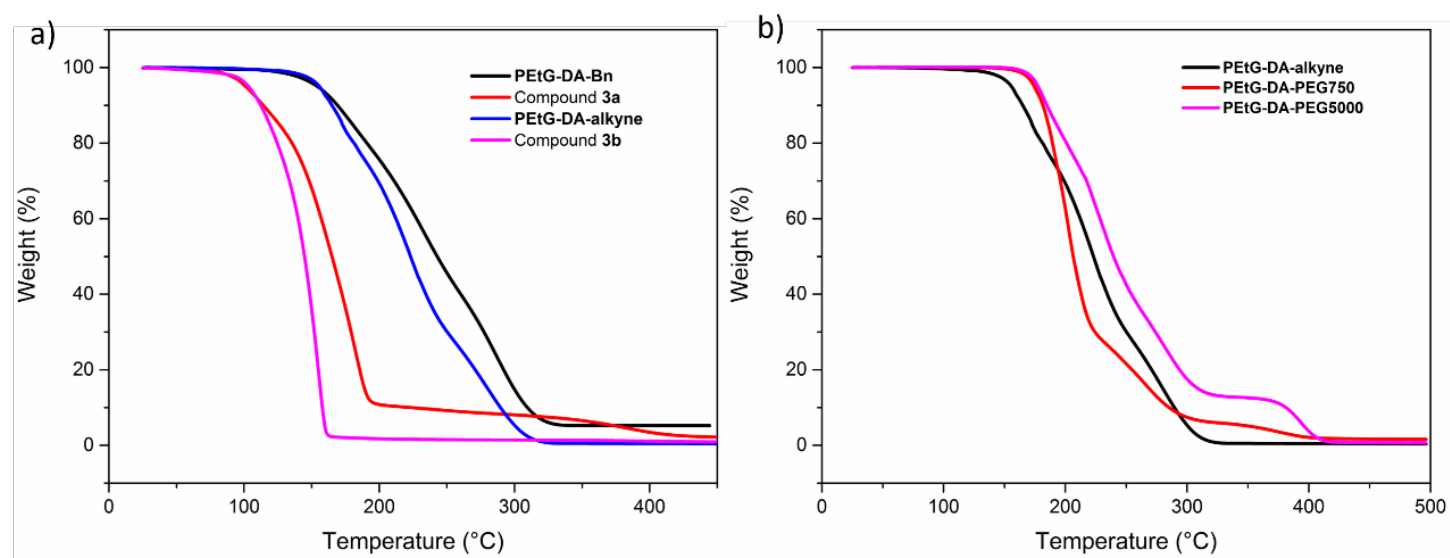

Figure S28. TGA curves of thermo-responsive a) end-caps and polymers; b) homopolymer PEtG compared with the PEtG-PEG block copolymers. It can be noted that the polymers were more thermally stable than the DA adduct itself (compound 3a or 3b), which degraded at $\sim 100{ }^{\circ} \mathrm{C}$. There are two possible explanations for this phenomenon: 1) the polymer may serve as a matrix to protect the end-cap decomposition; 2) the elimination reaction following the retro-DA reaction is the rate-limiting step for thermal depolymerization. In the block copolymers, the presence of a second decomposition step at $300{ }^{\circ} \mathrm{C}$ provides can be attributed to the PEG block.

Table S1. Molecular weights, measured by SEC in THF relative to PMMA standards, for the polymers, and thermal properties as measured by TGA. $\mathrm{T}_{\mathrm{O}}=$ onset degradation temperature measured by TGA.

\begin{tabular}{|c|c|c|c|}
\hline Polymer & $\mathrm{M}_{\mathrm{n}}(\mathrm{SEC})(\mathrm{kg} / \mathrm{mol})$ & Dispersity $(\bigoplus)$ & $\mathrm{T}_{\mathrm{O}}\left({ }^{\circ} \mathrm{C}\right)$ \\
\hline PEtG-DA-Bn & 33 & 1.8 & 169 \\
\hline PEtG-control $^{10}$ & 42 & 1.4 & $\mathrm{~N} / \mathrm{A}$ \\
\hline PEtG-DA-alkyne & 63 & 2.0 & 154 \\
\hline PEtG-DA-PEG750 & 59 & 1.9 & 177 \\
\hline PEtG-DA-PEG5000 & 35 & 2.0 & 171 \\
\hline Micelle-control $^{\text {1a }}$ & 40 & 2.1 & $\mathrm{~N} / \mathrm{A}$ \\
\hline Vesicle-control & 77 & 2.3 & $\mathrm{~N} / \mathrm{A}$ \\
\hline
\end{tabular}




\section{SEC traces for polymers}

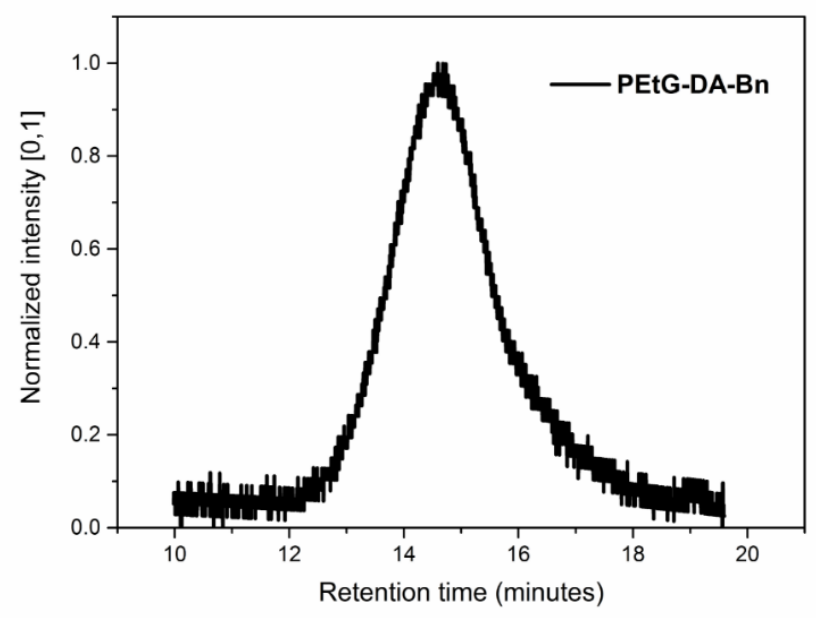

Figure S29. SEC curve of PEtG-DA-Bn.

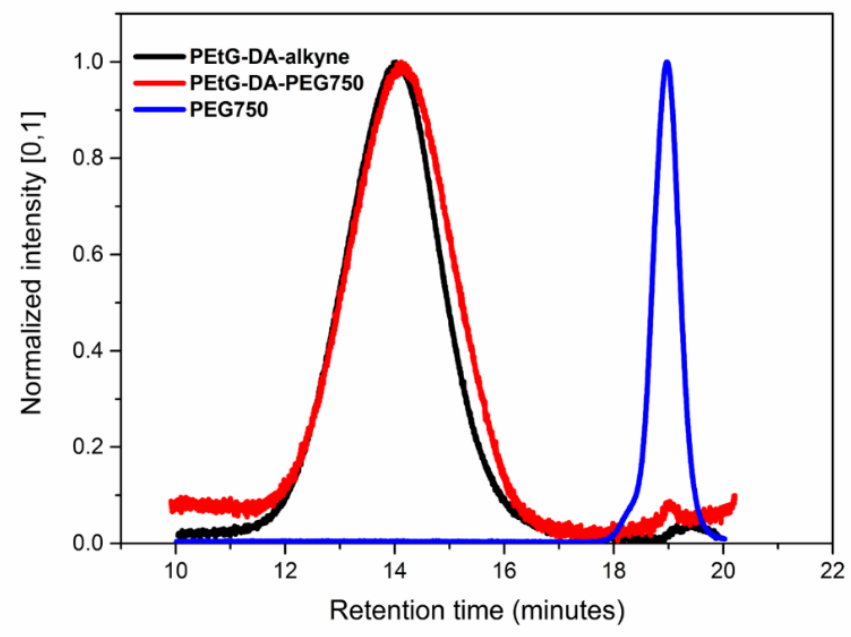

Figure S30. Comparison of SEC curves of PEtG-DA-alkyne, PEG 750 g/mol, and

PEtG-DA-PEG750. No increase in molar mass was observed upon coupling of PEG, which is consistent with previous work and can be attributed to the small mass fraction of the PEG as well as possible conformational changes that would cancel the effects of the addition of mass. This is consistent with our previous reports. ${ }^{1 \mathrm{a}, 6}$ 


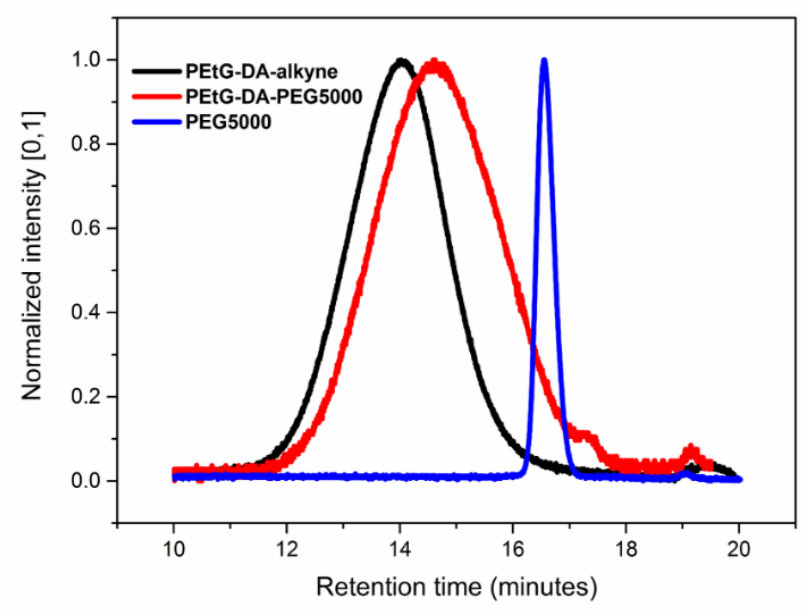

Figure S31. Comparison of SEC curves of PEtG-DA-alkyne, PEG $750 \mathrm{~g} / \mathrm{mol}$, and PEtG-DA-PEG5000. As THF is not an ideal solvent for PEG, after coupling with PEG5000, the hydrodynamic radius of PEG-DA-PEG5000 decreased rather than increased likely due to some polymer chain collapse. However the absence of a free PEG peak combined its presence in the NMR spectra clearly confirmed the presence of PEG in the block copolymer.

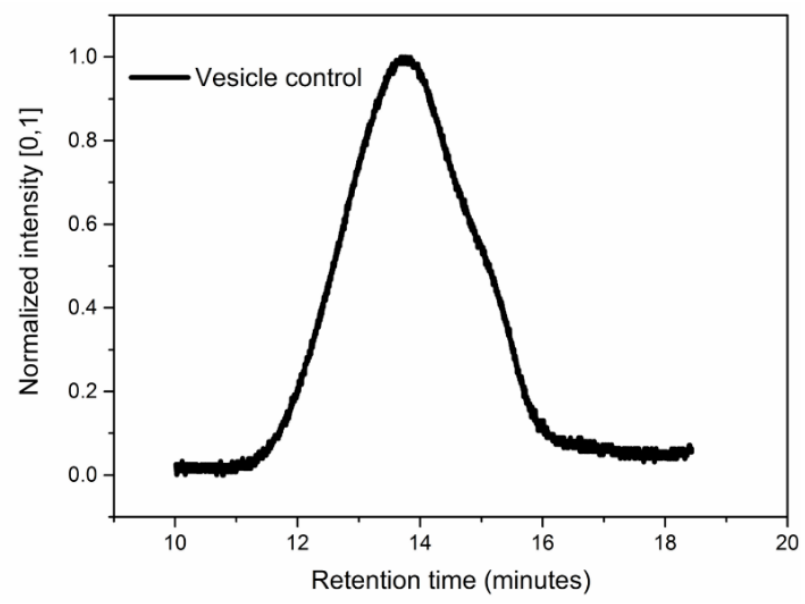

Figure S32. SEC curve of Vesicle-control. 


\section{DLS distributions of all assemblies}
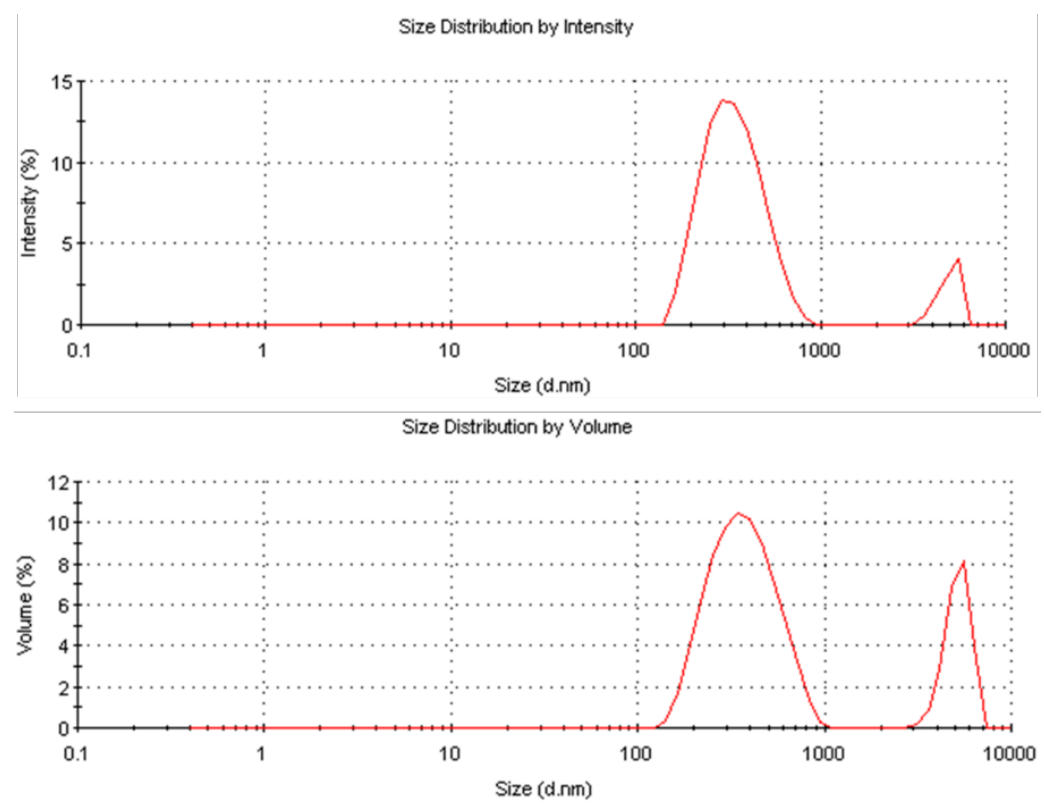

Figure S33. DLS intensity (top) and volume (bottom) distributions for PEtG-DA-PEG750 vesicles.
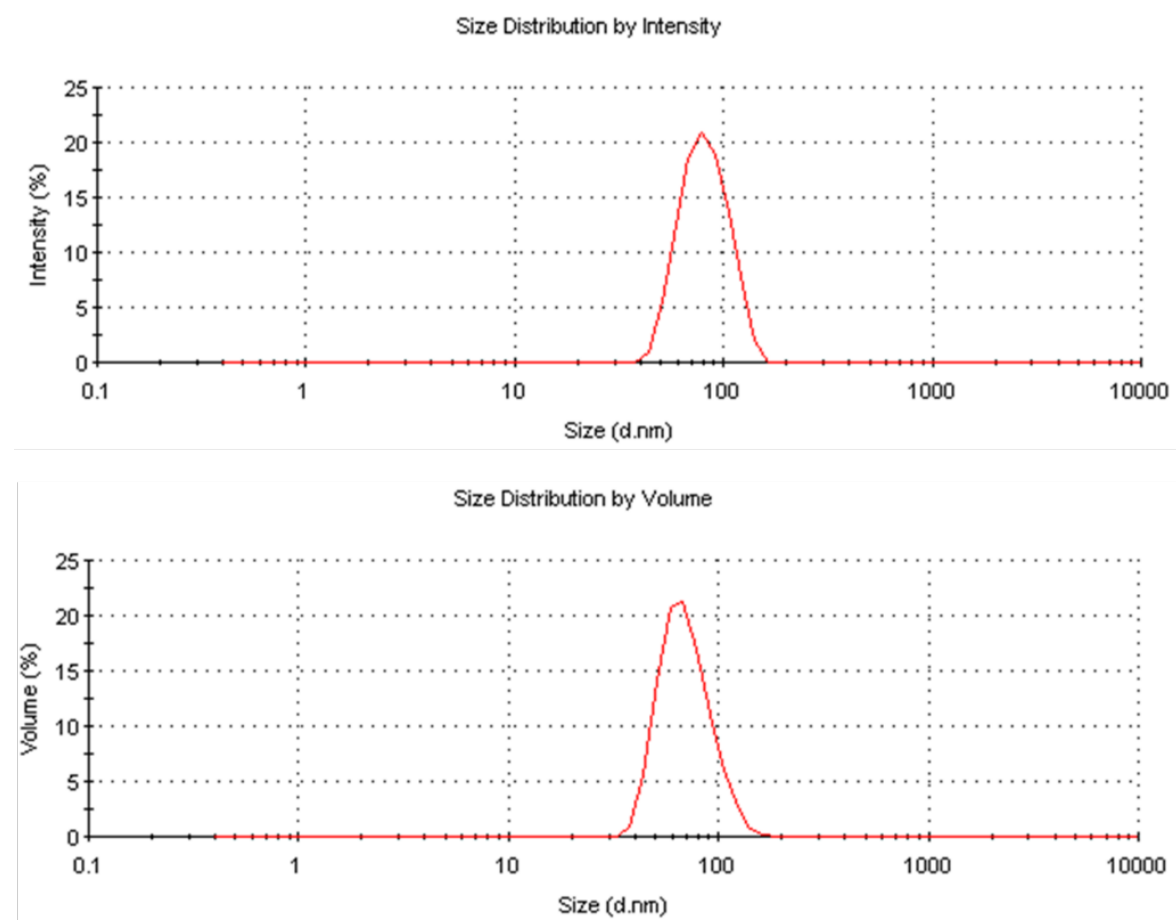

Figure S34. DLS intensity (top) and volume (bottom) distributions for PEtG-DA-PEG5000 micelles. 


\section{ChemComm}
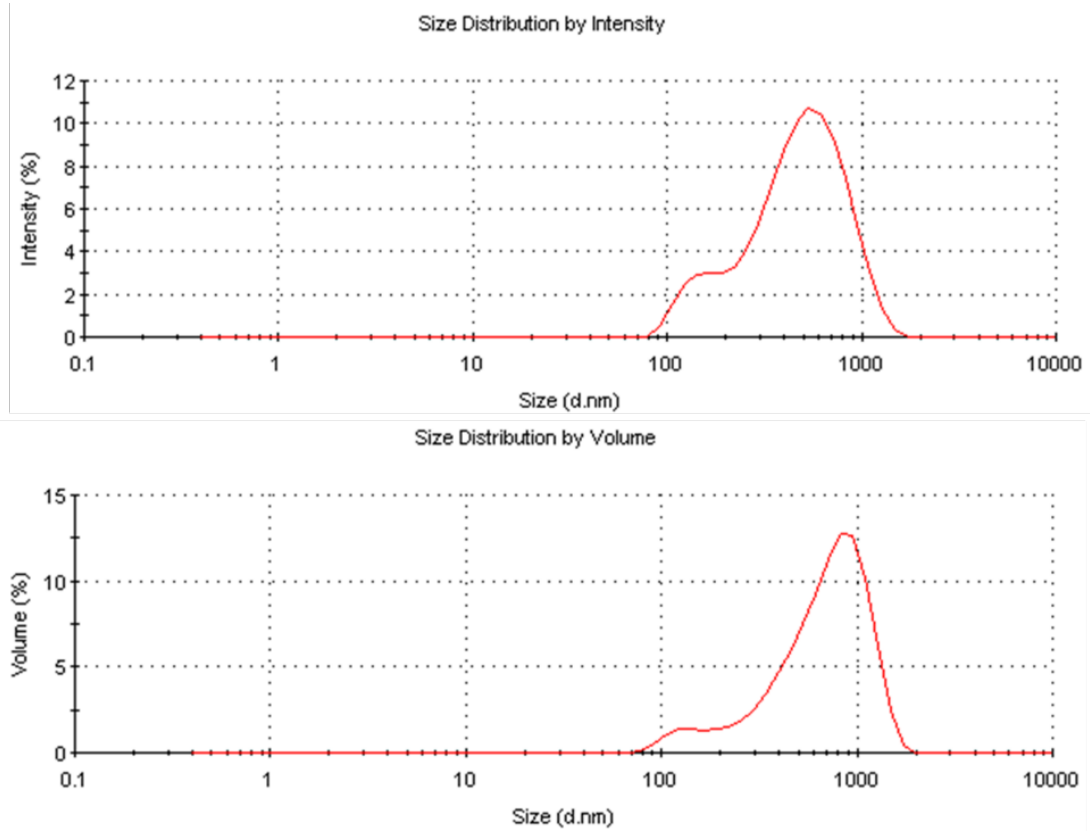

Figure S35. DLS intensity (top) and volume (bottom) distributions for Vesicle-control.
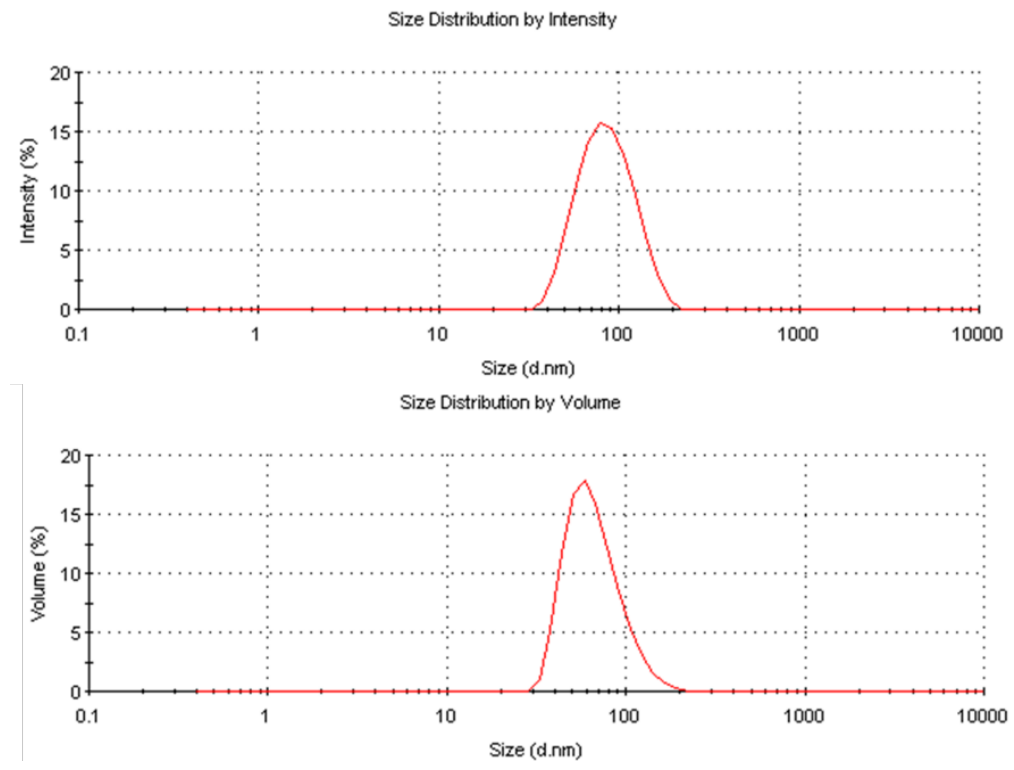

Figure S36. DLS intensity (top) and volume (bottom) distributions for Micelle-control. 


\section{Additional TEM images}

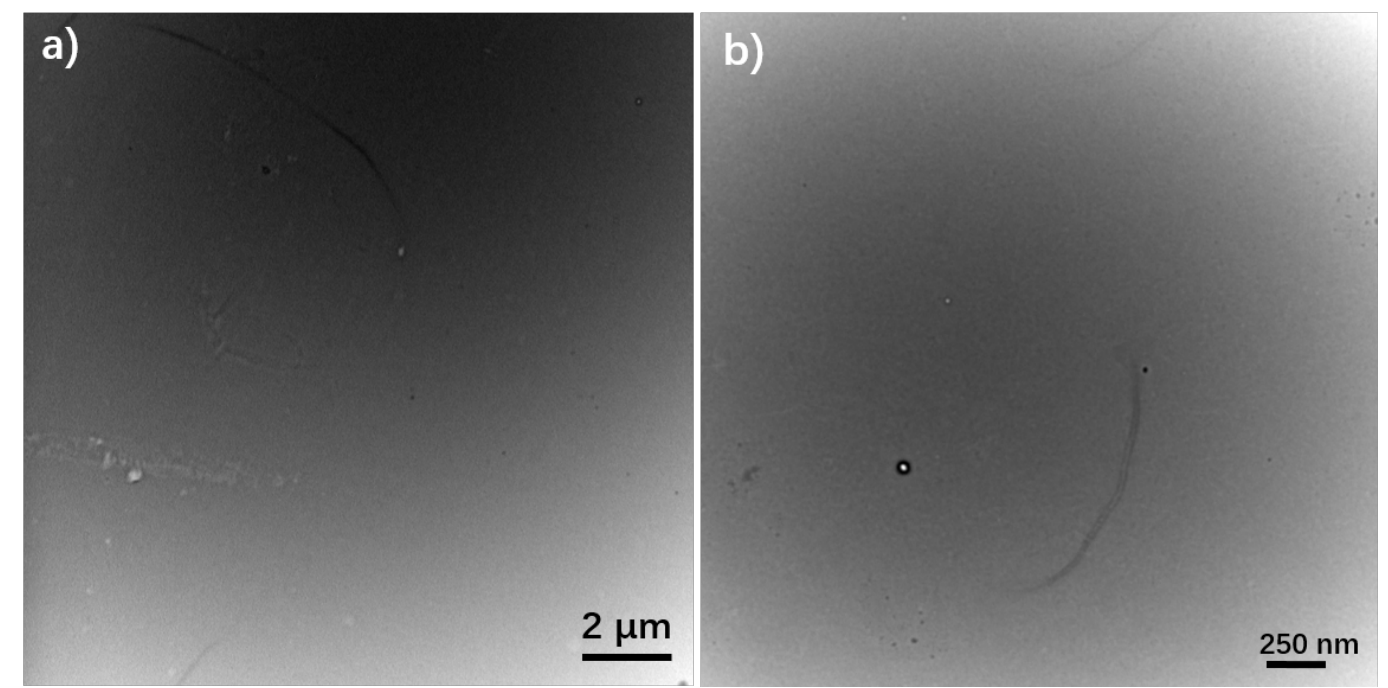

Figure S37. TEM images of a) PEtG-DA-PEG750 vesicles and b) PEtG-DA-PEG5000 micelles after incubation at $75{ }^{\circ} \mathrm{C}$ for $16 \mathrm{~h}$. No assemblies were observed.

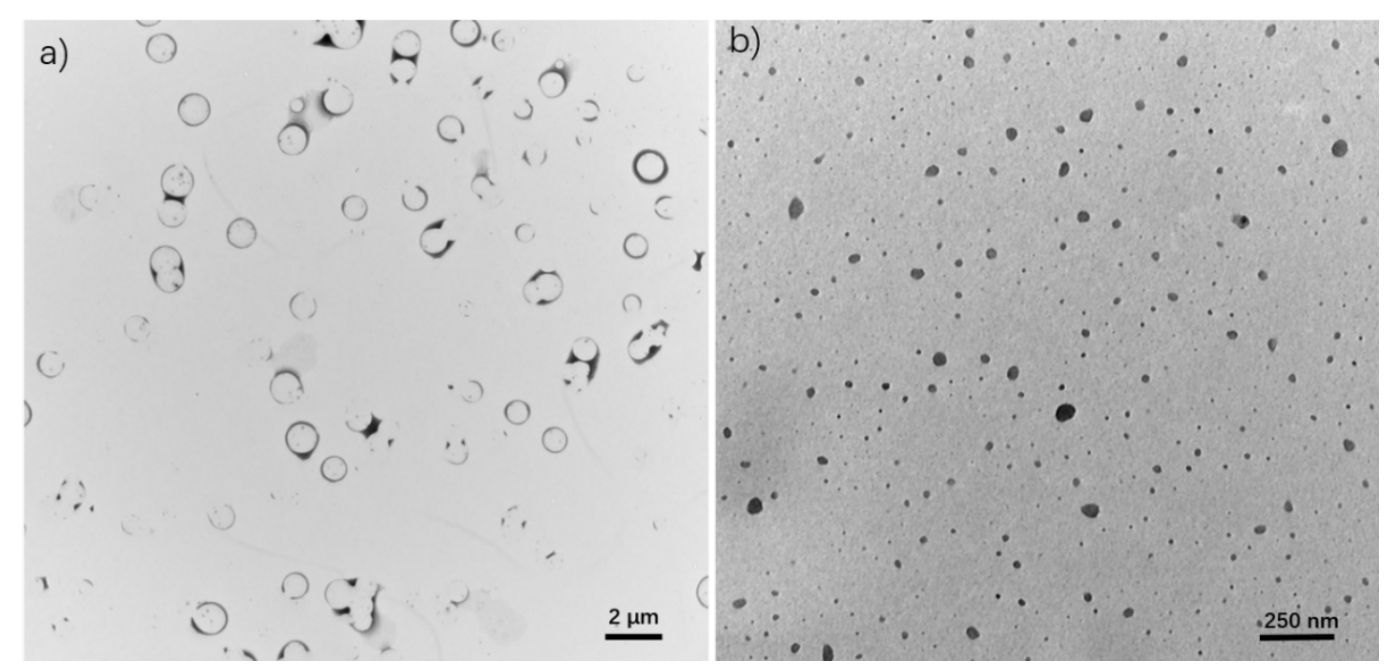

Figure S38. TEM images of a) Vesicle-control and b) Micelle-control. 


\section{ChemComm}

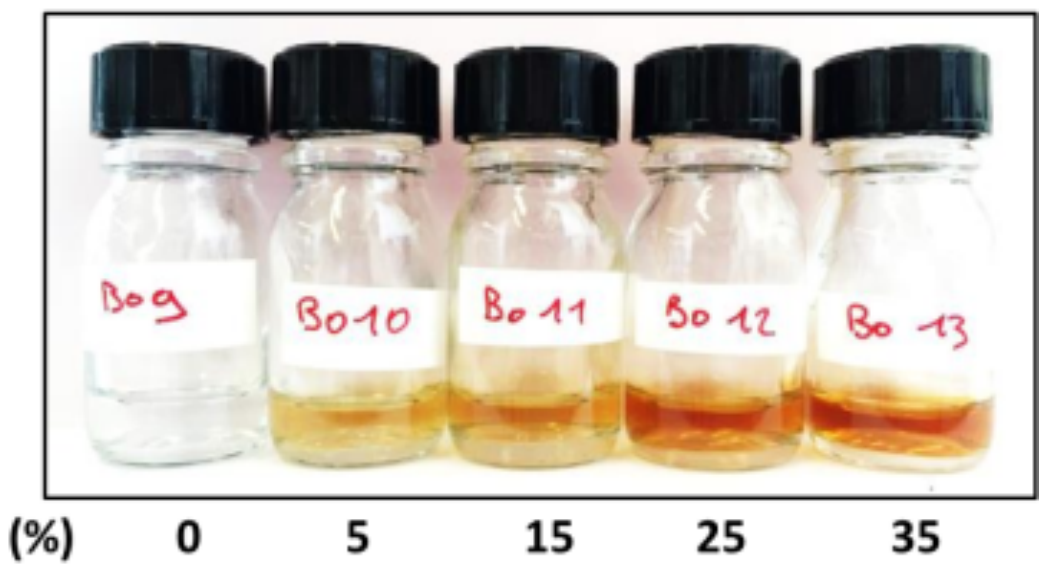

Figure S39. Photos of IONP-loaded PEtG-DA-PEG5000 micelles with increasing mass \% of IONP.

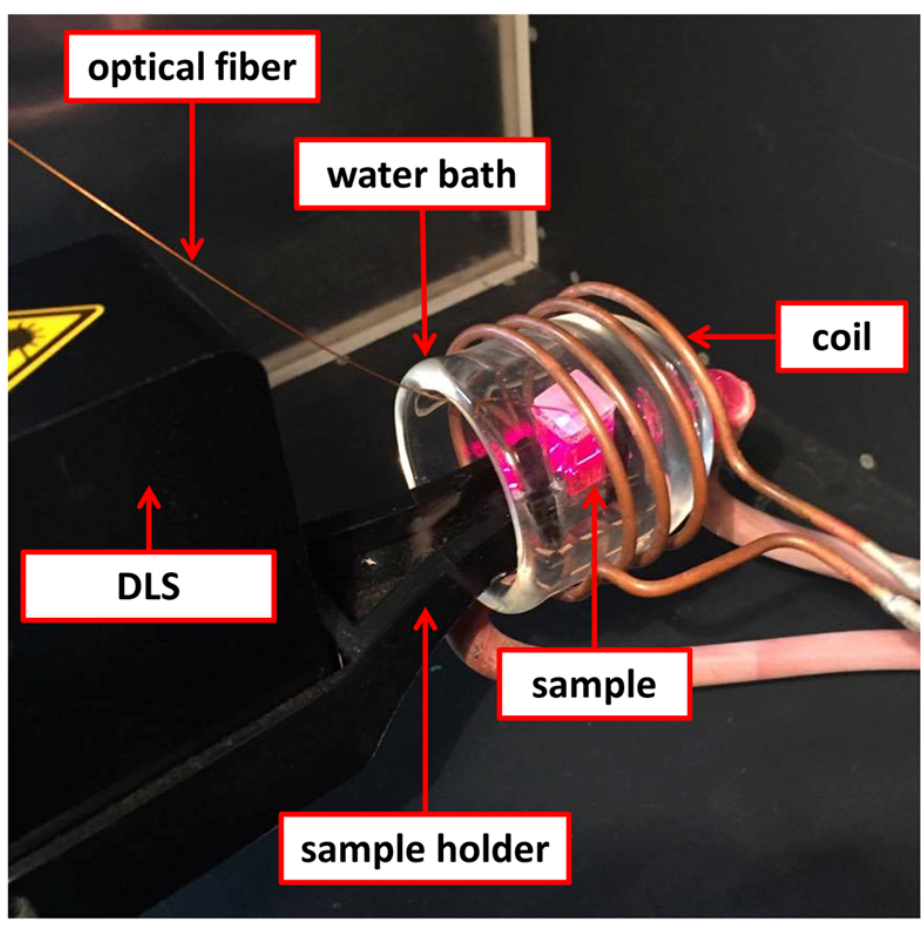

Figure S40. Photo of the dynamic light scattering magnetic hyperthermic set-up. 

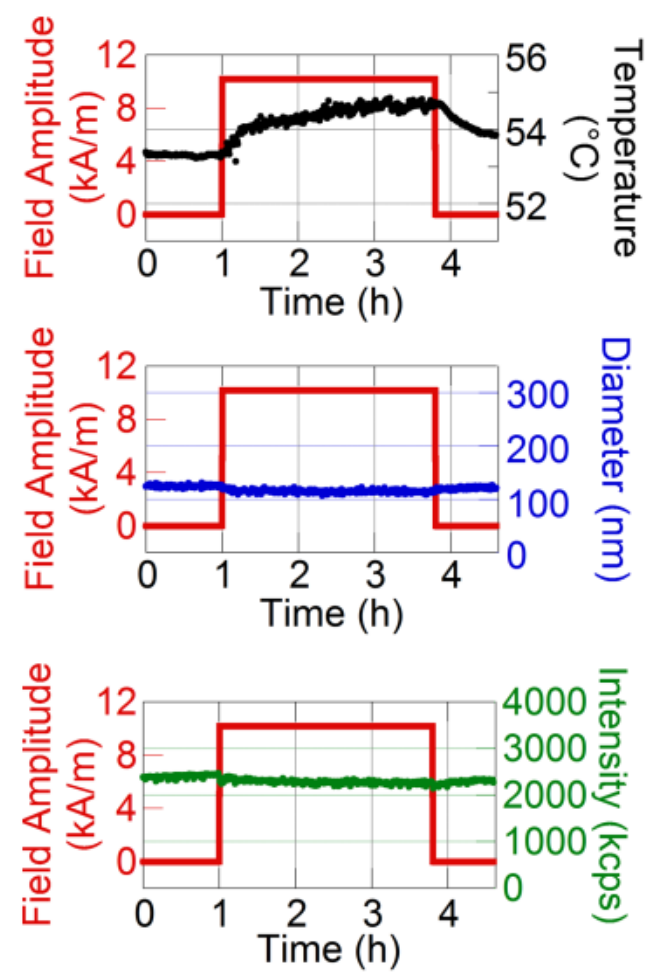

Figure S41. Bulk temperature, particle diameter, and count rate measured before, during, and after magnetic hyperthermia using an in situ DLS for IONP-loaded PEtG-DA-PEG5000 with a bulk temperature of $53{ }^{\circ} \mathrm{C}$.

\section{Study of the thermal degradation by small angle neutron scattering}

The thermal degradation of the thermosensitive micelles was also investigated by small-angle neutron scattering (SANS). Micelles loaded with IONPs were prepared as previously described, with few changes to adapt to this other characterization technique. The IONPs $\left(\mathrm{d}_{\text {TEM }}=10.5 \mathrm{~nm}\right)$ and the polymer were mixed in deuterated THF, and nano-precipitated in deuterated water to improve the contrast between the micelles and their solvent. Pure PEtG-DA-PEG5000 micelles (BO14) or magnetically loaded thermosensitive micelles (BO15, 35 mass \% iron oxide relative to polymer) were prepared this way, at a concentration of $0.6 \mathrm{mg} \cdot \mathrm{mL}^{-1}$. The effect of long heating on the structure of the micelles was evidenced by comparing the SANS curves (Fig. S42) before 
and after heating at $80{ }^{\circ} \mathrm{C}$ in an oven for $30 \mathrm{~min}$. The curves of micelles before heating were well fitted by a polydisperse sphere form factor multiplied by a "sticky hard sphere" structure factor to take into account short-range attractions. The fitted radius and volume fraction of the micelles were respectively $R_{0}=10.9 \mathrm{~nm}$ and $\phi=0.00028\left(R_{0}=11.7 \mathrm{~nm}\right.$ and $\left.\phi=0.00030\right)$ for the unloaded micelles BO14 (respectively magnetically loaded micelles BO15) with a high dispersity $\sigma=0.4$ (Log-normal distribution) in both cases. The weight-average radius of the micelles that take into account this Log-normal dispersity can be calculated using $R_{\mathrm{w}}=\left\langle R^{4}\right\rangle /\left\langle R^{3}\right\rangle=R_{0} \cdot \exp \left(7 \sigma^{2} / 2\right)$, leading to $R_{\mathrm{W}}=19.1 \mathrm{~nm}$ for pure micelles and $R_{\mathrm{W}}=20.5 \mathrm{~nm}$ for magnetic ones. These SANS sizes are still much lower than the hydrodynamic radius of the micelles found around $50 \mathrm{~nm}$. However, this can be explained by the relatively high hydration level of PEtG blocks compared to standard hydrophobic polymers, leading to a dominant contribution to the neutron scattering contrast from the dense dehydrated cores of the micelles compared to their hydrated shells. This is also why the fitted volume fractions around 0.03 vol\% are about twice lower than expected from the 0.6 $\mathrm{mg} / \mathrm{mL}$ total concentration in polymer.

The curves of the heat-treated micelles were not fitted by a model shape. Nonetheless, they can be interpreted by a drastic reduction of the volume fraction of suspended copolymer micelles, together with an increase of the size of the remaining objects (as ascribed to aggregation of the remaining IONPs). This SANS experiment thus brings another evidence of the thermosensitivity of PEtG-DA-PEG5000 copolymer micelles that did not disappear when embedding IONPs in their core. 


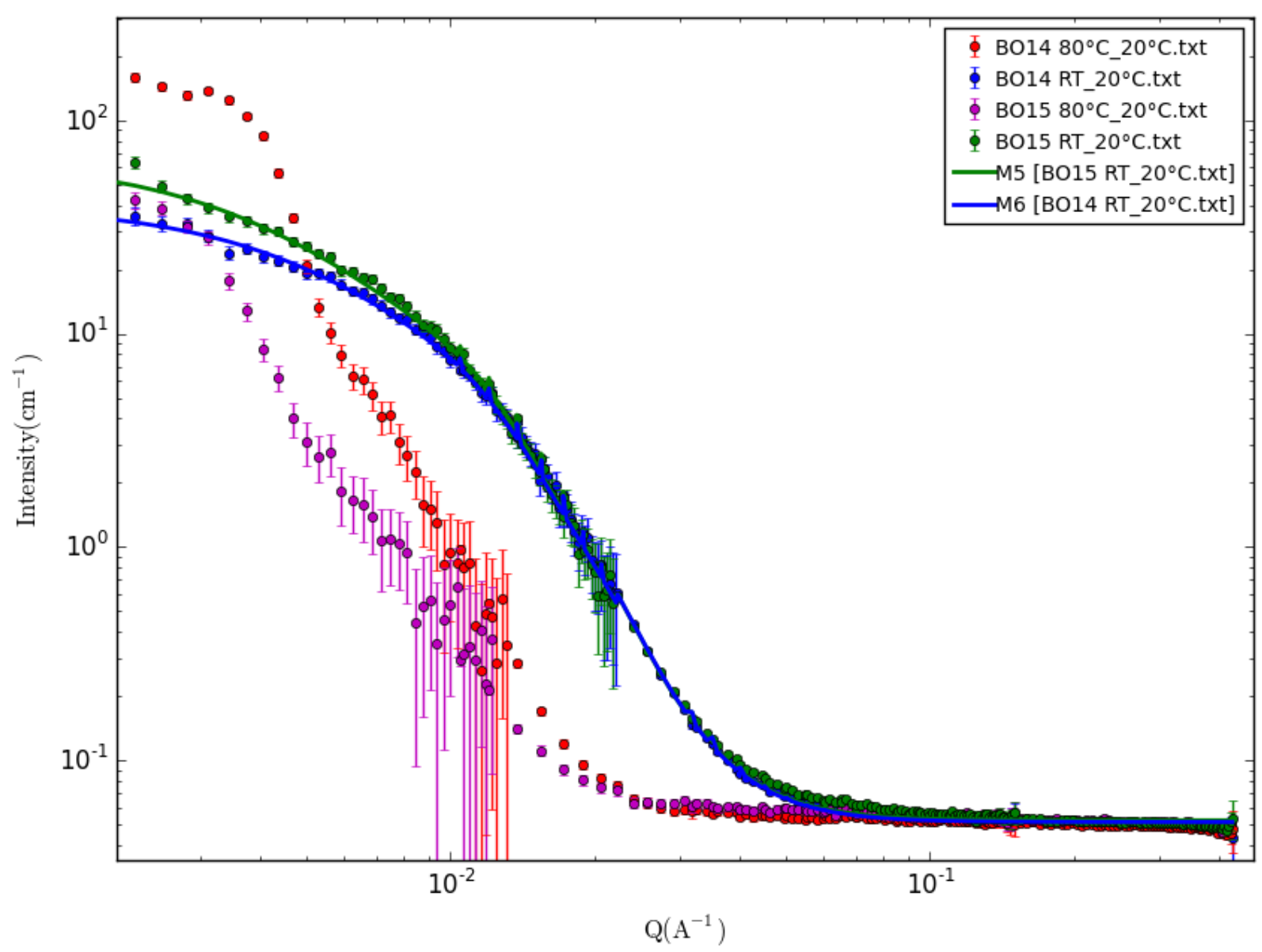

Figure S42. SANS curves of pure micelles BO14 and magnetically loaded micelles BO15 before and after treatment at $80^{\circ} \mathrm{C}$ for $30 \mathrm{~min}$ (the SANS curves being acquired afterwards, at $20^{\circ} \mathrm{C}$ ). The curves of the untreated micelles were fitted by a polydisperse sphere form factor multiplied by a "sticky hard sphere" structure factor. Solid lines represent simulated curves using the SasView 3.1.2 software (http://sasview.org) with a polydisperse sphere form factor $P(q)$ multiplied by a "sticky hard sphere" structure factor $S(q)$ to take into account short-range attractive interactions between the micelles. ${ }^{7}$ In addition to the SLDs that were fixed to their theoretical values, the parameters of the polydisperse sphere form factor were the volume fraction $\phi$, the incoherent background level, the median radius $\mathrm{R}_{0}$ of the micelles and the width $\sigma$ of the distribution of radii as described by a Log-normal law. Other fitting parameters of the sticky hard sphere structure factor $S(q)$ were the "stickiness" $\tau=0.047 \pm 0.006$ (respectively $\tau=0.036 \pm 0.0015$ ) and the "perturbation distance" $\varepsilon=0.637 \pm 0.019$ (respectively $\varepsilon=0.605 \pm 0.012$ ) for the pure micelles BO14 (respectively magnetically loaded micelles BO15). 


\section{ChemComm}

\section{References}

1 a) B. Fan, J. F. Trant, A. D. Wong, E. R. Gillies, J. Am. Chem. Soc., 2014, 136, 10116-10123; b) B. Fan, J. F. Trant, R. E. Yardley, A. J. Pickering, F. Lagugné-Labarthet, E. R. Gillies, Macromolecules, 2016, 49, 7196-7203.

2 M. Sortino, V. Cechinel Filho, R. Corrêa, S. Zacchino, Bioorg. Med. Chem., 2008, 16, 560-568.

3 M. Link, X. Li, J. Kleim, O. S. Wolfbeis, Eur. J. of Org. Chem., 2010, 2010, 6922-6927.

4 a) G. Hemery, A. C. Keyes Jr, E. Garaio, I. Rodrigo, J. A. Garcia, F. Plazaola, E. Garanger, O. Sandre, Inorg. Chem. , 2017, 56, 8232-8243; b) D. Caruntu, G. Caruntu, Y. Chen, C. J. O'Connor, G. Goloverda, V. L. Kolesnichenko, Chem. Mater., 2004, 16, 5527-5534.

5 G. Hemery, E. Garanger, S. Lecommandoux, A. D. Wong, E. R. Gillies, B. Pedrono, T. Bayle, D. Jacob, O. Sandre, J. Phys. D: Appl. Phys., 2015, 48, 494001.

6 B. Fan, E. R. Gillies, Mol. Pharmaceutics, 2017, 14, 2548.

7 a) R.J. Baxter, J. Chem. Phys. 1968, 49, 2770-2774; b) S. V. G. Menon, C. Manohar, K. S. Rao, J. Chem. Phys. 1991, 95, 9186-9190 